\begin{abstract}
UNIVERSIDADE DE SÃO PAULO
FACULDADE DE FILOSOFIA, LETRAS E CIÊNCIAS HUMANAS

DEPARTAMENTO DE LETRAS MODERNAS

PROGRAMA DE PÓS-GRADUAÇÃO EM ESTUDOS LINGUÍSTICOS, LITERÁRIOS

E TRADUTOLÓGICOS EM FRANCÊS
\end{abstract}

LIVIA CRISTINA ECCARD PINTO

A mediação no ensino/aprendizagem de língua estrangeira para crianças: francês em múltiplas linguagens

São Paulo 


\author{
UNIVERSIDADE DE SÃO PAULO \\ FACULDADE DE FILOSOFIA, LETRAS E CIÊNCIAS HUMANAS \\ DEPARTAMENTO DE LETRAS MODERNAS \\ PROGRAMA DE PÓS-GRADUAÇÃO EM ESTUDOS LINGUÍSTICOS, LITERÁRIOS \\ E TRADUTOOLÓGICOS EM FRANCÊS
}

\title{
A mediação no ensino/aprendizagem de língua estrangeira para crianças: francês em múltiplas linguagens
}

Livia Cristina Eccard Pinto

\begin{abstract}
Dissertação apresentada ao Programa de PósGraduação em Estudos Linguísticos, Literários e Tradutológicos em Francês da Faculdade de Filosofia, Letras e Ciências Humanas da Universidade de São Paulo, para a obtenção do título de Mestre em Letras.
\end{abstract}

Orientador: Prof. Dr. Paulo Roberto Massaro

São Paulo 
Nome: ECCARD-PINTO, Livia Cristina

Título: A mediação no ensino/aprendizagem de língua estrangeira para crianças: francês em múltiplas linguagens

Aprovada em:

Banca Examinadora

Prof. Dr. Instituição:

Julgamento:

Assinatura:

Prof. Dr. Instituição:

Julgamento:

Assinatura:

Prof. Dr. Instituição:

Julgamento: Assinatura: 


\section{AGRADECIMENTOS}

A todos aqueles que, algum dia, participaram da minha formação e, em particular, para a realização deste projeto.

Aos meus alunos que me motivam a continuar na profissão.

Aos professores e funcionários do Departamento de Letras Modernas - FFLCH USP.

Às $\operatorname{Prof}^{\text {as }} \operatorname{Dr}^{\text {as }}$ Denise Radanovic Vieira e Eliane Gouvêa Lousada, pelas preciosas sugestões durante o exame de qualificação.

À CAPES, pelo apoio financeiro.

À minha família e amigos, pela paciência em escutar mesmo sem entender.

E, por fim, ao Prof. Dr. Paulo Roberto Massaro, pela orientação e, sobretudo, pela paciência.

Merci beaucoup à tous! 


\section{RESUMO}

A partir do conceito de mediação sustentado por Vigotski (1998), esta pesquisa propõe uma reflexão sobre a interveniência de um fantoche - agente mediador - no processo de apropriação da língua francesa por crianças em fase de aquisição da escrita, bem como sobre as contribuições que atividades didáticas concebidas a partir de múltiplas linguagens poderiam trazer para o desenvolvimento infantil ao estimular as inteligências plurais (GARDNER, 1994). Para tanto, realizamos um estudo de caso, caracterizado pela elaboração e condução de uma oficina experimental de língua francesa com crianças de 6 a 8 anos inscritos em duas instituições (uma paraescolar e outra escolar), situadas ambas no município de Nova Friburgo, cidade do Estado do Rio de Janeiro, colonizada por imigrantes suíços no século XIX. Como metodologia de pesquisa, servimo-nos da análise qualitativa de dados, obtidos através de vídeo-gravações da oficina e do diário de itinerância da pesquisadora professora animadora. Os resultados mostram não apenas as relações criadas entre as crianças e o agente mediador, mas também suas atitudes face à gama de atividades ludo-corporais oferecida pela professora-animadora.

Palavras-chave: desenvolvimento infantil, mediação, FLE, corpo, múltiplas linguagens 


\begin{abstract}
From the concept of mediation sustained by Vigotski (1998), this research proposes a thought about the intervention of a puppet - mediating agent - in the process of appropriation of the French language by children in writing acquisition phase, as well as about the contributions that didactic activities conceived from multiple languages could bring to child development by stimulating the multiple intelligences (GARDNER, 1994). For such, we conducted a case study, characterized by the elaboration and leading of an experimental workshop of the French language with children of ages from 6 to 8 enrolled in two institutions (school and after-school) both situated in Nova Friburgo, a city in the state of Rio de Janeiro, colonized by Swiss immigrants in the 19th century. As research methodology we made use of the qualitative data analysis, obtained from video-recordings of the workshop and logbook of the researcher professor animator. The results do not show only the bond created between the children and the mediating agent, but also their attitudes face the range of ludobodily activities offered by the teacher.
\end{abstract}

Keywords: child development, mediation, FLE, body, multiple languages 


\section{RÉSUMÉ}

A partir du concept de médiation soutenu par Vigotski (1998), cette recherche propose une réflexion aussi bien sur l'intervention d'un guignol - agent médiateur - dans le processus d'appropriation de la langue française par des enfants en phase d'acquisition du langage écrit, que sur les contributions que des activités didactiques conçues à partir de langages multiples pourraient apporter au développement infantile tout en stimulant des intelligences plurielles (GARDNER, 1994). Pour ce faire, nous avons entrepris une étude de cas caractérisée par l'élaboration et par la mise en œuvre d'un atelier expérimental de langue française auprès d'enfants de 6 à 8 ans inscrits à deux institutions (l'une parascolaire et l'autre scolaire), toutes les deux situées à Nova Friburgo, une ville de l'Etat de Rio de Janeiro, colonisée par des immigrants suisses au $\mathrm{XIX}^{\mathrm{e}}$ siècle. Comme méthodologie de recherche, nous nous sommes servis de l'analyse qualitative de données, obtenues à travers des enregistrements-vidéo de l'atelier et du journal de bord de la chercheuse enseignante animatrice. Les résultats montrent non seulement les liens créés entre les enfants et l'agent médiateur, mais aussi leurs attitudes face à l'éventail d'activités ludocorporelles offert par l'animatrice.

Mots-clés : développement infantile, médiation, FLE, corps, langages multiples 


\section{LISTA DE FIGURAS}

Figura 1 - Croograma de realização da coleta de dados

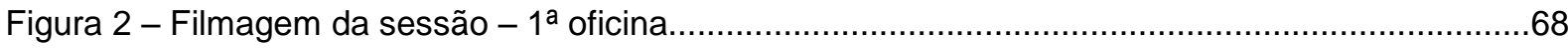

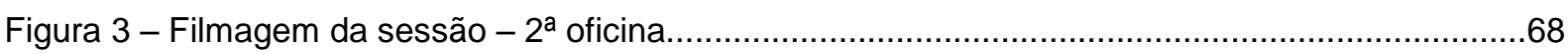

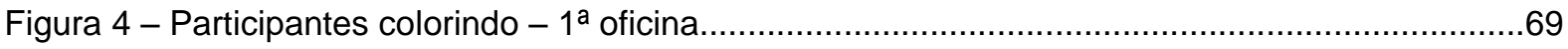

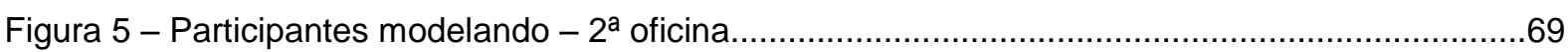

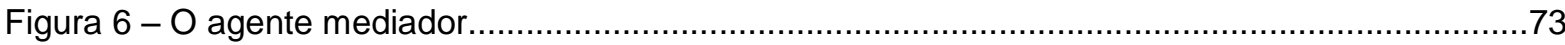

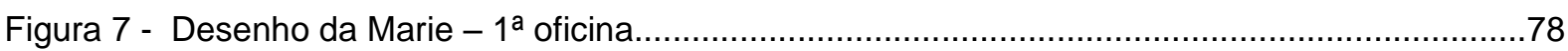

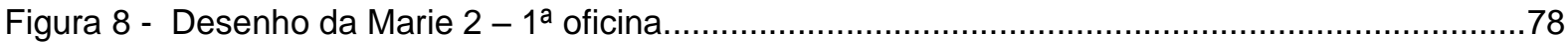

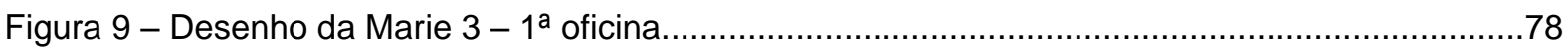

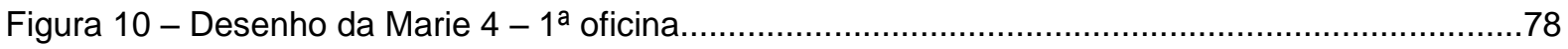

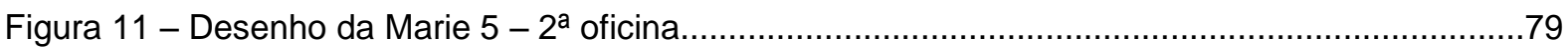

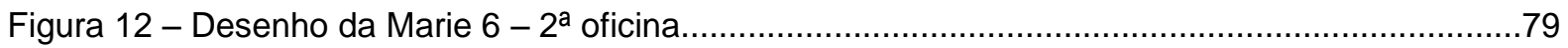

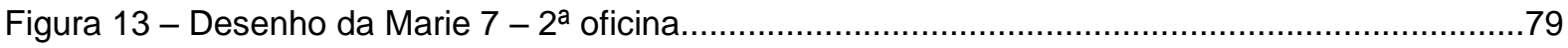

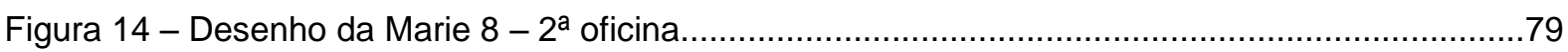

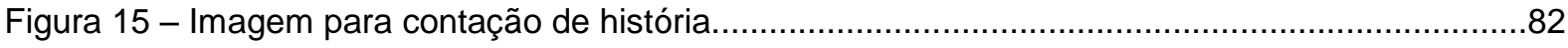

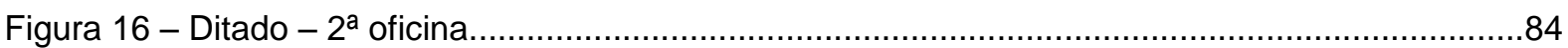

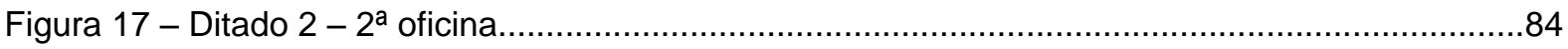

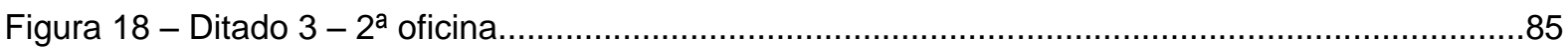

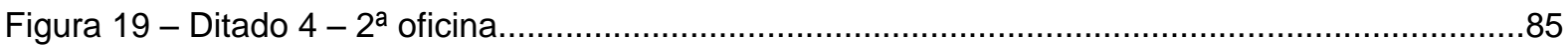

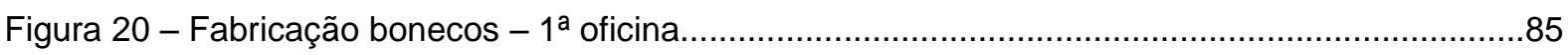

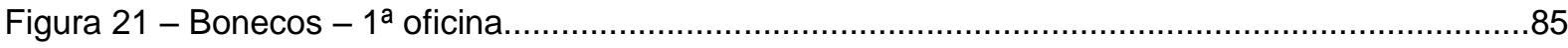

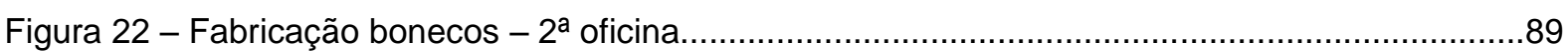

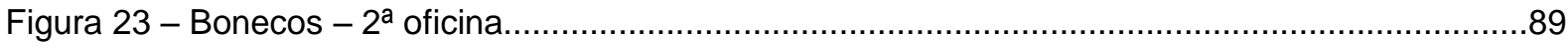

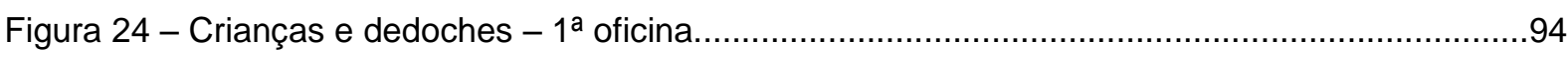

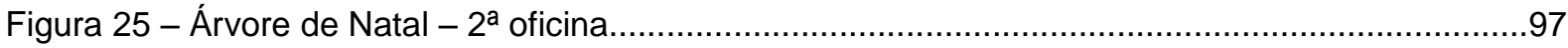




\section{SUMÁRIO}

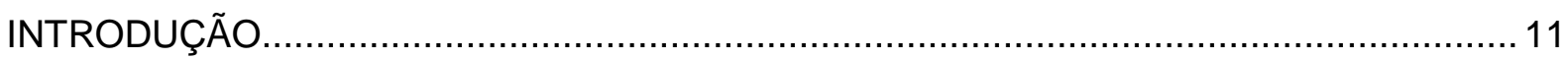

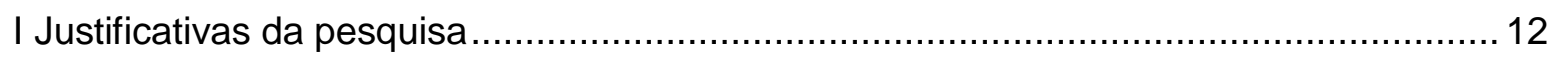

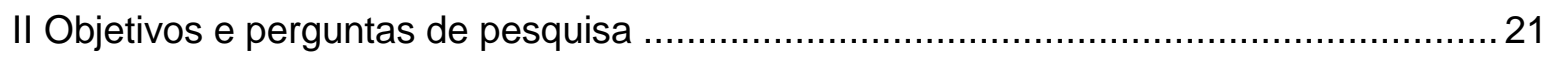

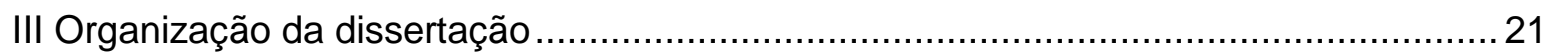

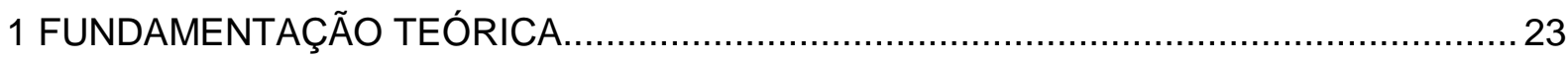

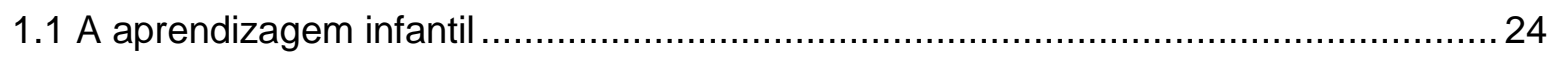

1.2 O lúdico e a corporalização da língua estrangeira .....................................................38

1.2.1 Jogo, brincadeira, múltiplas linguagens e mediação ………………………........ 38

1.2.2. Jogo dramático infantil, corporalização e mediação …………………………….... 48

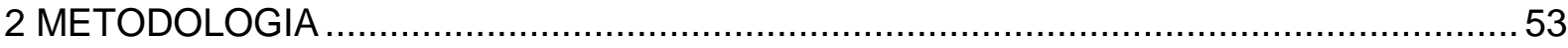

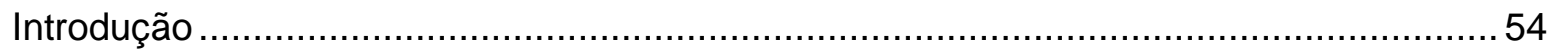

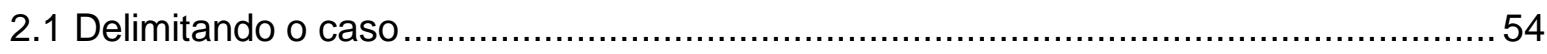

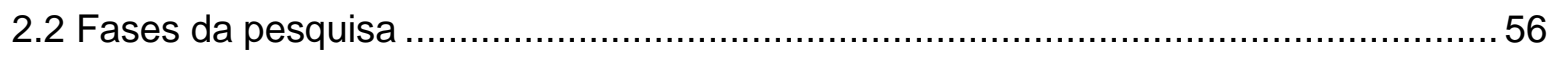

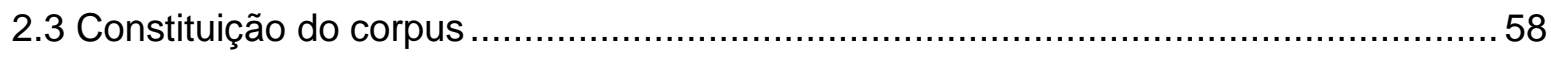

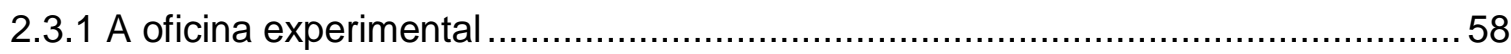

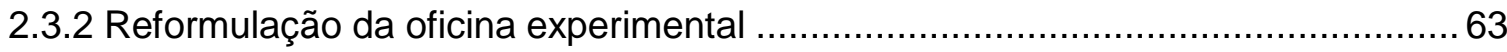

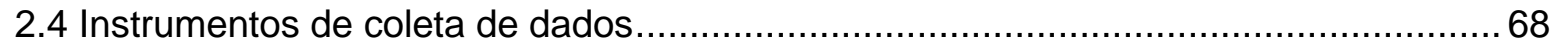

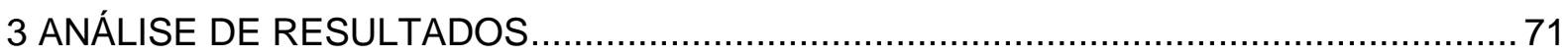

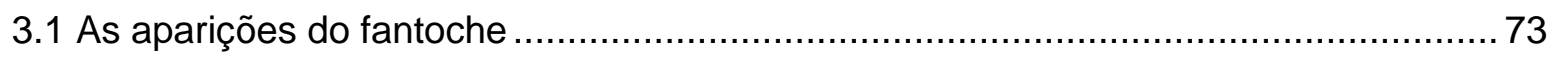

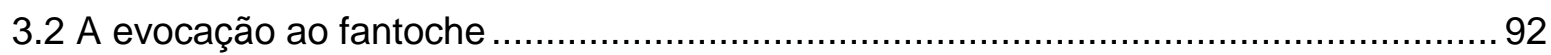

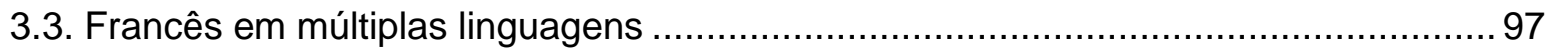

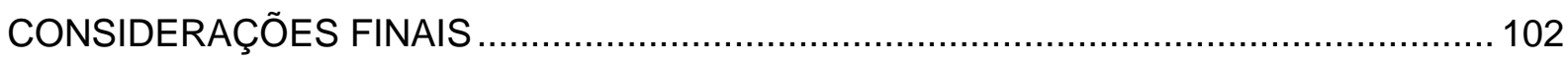

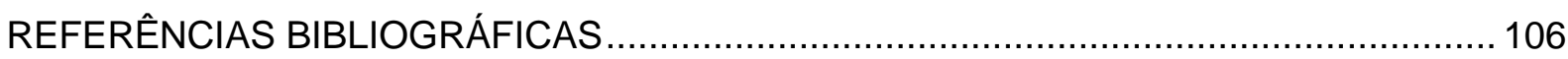


"Les enfants vont à l'école pour apprendre à vivre dans le monde qui les entoure. Parler une ou plusieurs langues étrangères fait désormais partie de ce «vivre dans le monde. »

(Vanthier, 2009) 


\section{INTRODUÇÃO}




\section{Justificativas da pesquisa}

Meu interesse pelo ensino voltado às crianças começou quando ainda cursava a Graduação em Letras Português/Francês na Universidade Federal de Viçosa. Nesta universidade, tive a oportunidade de desenvolver uma monografia de conclusão de curso, orientada pela $\operatorname{Prof}^{\mathrm{a}}{ }^{\mathrm{D}}{ }^{\mathrm{a}}$ Christianne Benatti Rochebois, cuja discussão teve como epicentro uma oficina experimental de francês língua estrangeira - por mim ministrada e destinada a crianças matriculadas na pré-escola - no Laboratório de Desenvolvimento Infantil $^{1}$ da Universidade.

Naquela época, sob a orientação da docente, mergulhei em obras que fundamentariam, um ano mais tarde, a monografia. Dentre as obras lidas, destaco a de Vanthier (2009) ${ }^{2}$, visto que a autora discute tanto a aprendizagem de língua estrangeira por crianças, quanto seu ensino, fornecendo ao professor atividades diversificadas adaptadas a determinadas faixas etárias.

Assim, inspirada por um lado em questões levantadas por Vanthier atinentes à Teoria das Inteligências Plurais de Gardner $(1994 ; 1995)^{3}$ e, por outro, reatualizando leituras feitas ao longo da licenciatura, elaborei e discuti com a orientadora sequências didáticas centradas em atividades lúdicas a fim de subsidiar não só o processo de aquisiçãoaprendizagem da língua estrangeira, mas também o desenvolvimento cognitivo integral daqueles aprendizes do Laboratório de Desenvolvimento Infantil.

Com efeito, o estudo bibliográfico e as elaborações de sequências didáticas destinadas a um público não alfabetizado haviam apontado para a necessidade de promover ações pedagógicas que atrelassem a Arte à Educação. Embora intuitiva e

\footnotetext{
${ }^{1}$ O Laboratório de Desenvolvimento Infantil é um espaço de formação profissional e tem por finalidade atender às atividades de ensino, pesquisa e extensão na Universidade Federal de Viçosa, tendo como objeto de estudo a criança e sua respectiva família. Para mais detalhes: http://www.ldi.ufv.br

${ }^{2}$ VANTHIER, Hélène. L'enseignement aux enfants en classe de langue. Paris: CLE, 2009.

${ }^{3}$ GARDNER, Howard. Estruturas da mente: A Teoria das Inteligências Múltiplas. Trad. Sandra Costa. Porto Alegre: Artmed, 1994; GARDNER, Howard. Inteligências múltiplas: a teoria na prática. Trad. Maria Adriana Veríssimo Veronese. Porto Alegre: Artes Médicas, 1995.
} 
empiricamente, procurei desenvolver atividades que abrangessem múltiplas linguagens . Na conclusão da monografia, destaquei a forte motivação das crianças por este tipo de atividades e demonstrei a necessidade de dar continuidade à discussão de experiências deste tipo - aliando Arte, Educação e Língua Estrangeira - por meio de pesquisas mais aprofundadas.

Foi a partir desta necessidade de aprofundamento que decidi desenvolver uma pesquisa de Mestrado neste domínio, para melhor compreender o processo de aprendizagem de língua estrangeira por crianças, bem como refletir sobre suas implicações para o trabalho docente, o que poderia, sob meu ponto de vista, auxiliar professores que se encontram na mesma situação de ensino que eu.

Foi assim que no início de 2012, após ter sido aprovada no processo seletivo, comecei minha Pós-Graduação junto ao Programa de Estudos Linguísticos, Literários e Tradutológicos em Francês da Universidade de São Paulo, sob orientação do Prof. Dr. Paulo Roberto Massaro.

Fomentado pela Coordenação de Aperfeiçoamento de Pessoal de Nível Superior (CAPES) durante 15 meses $^{4}$, o projeto de pesquisa se baseou na discussão do processo de mediação no ensino/aprendizagem para crianças e suas implicações para a concepção de uma proposta metodológica desenvolvida ao longo de oficinas experimentais que, por sua vez, foram constituídas por atividades didáticas centradas em múltiplas linguagens.

Ainda que no Brasil muitas publicações e trabalhos acadêmicos abordem as implicações do paradigma teórico-metodológico da Arte-Educação ${ }^{5}$ em diferentes situações e contextos de ensino-aprendizagem, pesquisas sobre suas relações com a Didática de

\footnotetext{
${ }^{4}$ A bolsa me foi concedida em setembro de 2012 e, em fevereiro de 2014, optei por abdicar dela por ter conseguido vínculo empregatício junto à Aliança Francesa de Nova Friburgo, onde assumi turmas de níveis iniciante e intermediário para adultos, adolescentes e crianças.
}

${ }^{5}$ BARBOSA, Ana Mae. Arte educação no Brasil. São Paulo: Perspectiva, 1978 Arte-Educação: conflitos/acertos. São Paulo: Editora Max Limonad, 1984; Paulo: Editora Max Limonad, 1984. 
Línguas Estrangeiras se encontram em fase incipiente; poucos pesquisadores têm se dedicado ao tema.

No específico domínio das intersecções entre Teatro-Educação e Francês Língua Estrangeira destacam-se sobretudo as publicações de Massaro $(2001 ; 2007 ; 2008)^{6}$ e as de Reis $(2008,2010,2011)^{7}$. Vale salientar que Massaro desenvolve os projetos de pesquisa "O texto teatral, o jogo dramático e a voz do aprendiz de língua estrangeira" desde 2006 e “Práticas estéticas e apropriação de línguas estrangeiras” desde 2011. Este segundo projeto tem por objeto a análise de performances em língua estrangeira, entendidas como acontecimentos de natureza estética que articulam múltiplas linguagens ${ }^{8}$.

No que se refere ao uso de múltiplas linguagens na escola, embora muitas obras descrevam essa temática do ponto de vista prático ${ }^{9}$, constata-se, em suma, que há uma grande lacuna bibliográfica do ponto de vista teórico tanto sobre a interveniência de múltiplas linguagens para o desenvolvimento cognitivo infantil, bem como suas prováveis implicações no processo de ensino/aprendizagem de língua estrangeira (LE). Ressalta-se ainda que a maioria das obras que abordam esse tema focalizam-no do ponto de vista, seja do segundo ciclo do Ensino Fundamental, seja do Ensino Médio ${ }^{10}$.

Sendo assim, incidindo sobre uma possível intersecção entre a Arte-Educação e a Didática de LE na Educação Infantil, nossa pesquisa aborda elementos teóricos e

6 MASSARO, Paulo Roberto. Teatro e Língua Estrangeira, entre teoria(s) e prática(s): percursos entre o vislumbre e o olhar. Dissertação de Mestrado. Universidade de São Paulo, 2001; O silêncio e a voz do texto teatral em francês, língua estrangeira. Tese de doutorado. Universidade de São Paulo, 2007; Teatro e língua estrangeira: entre teoria(s) e prática(s). São Paulo: paulistana, 2008.

${ }^{7}$ REIS, Maria da Glória Magalhães dos. O jogo teatral e o jogo dramático no ensino de Francês Língua Estrangeira. Tese de doutorado. Universidade de São Paulo, 2008; ; GUSMAO, Jéssica. A questão da oralidade no ensino de língua estrangeira jogos e textos dramáticos no desenvolvimento da expressão oral em língua estrangeira. Revista Desempenho, v. 11, 2010, p. 84-98; _. A expressão em cena: a afetividade, o corpo e a voz na apropriação da língua estrangeira. In: ANDRADE, Mariana R. Mastrella-de. (Org.). Afetividade e emoções no ensino/aprendizagem de línguas: múltiplos olhares. Campinas: Pontes Editores, 2011, p. 215248.

${ }^{8}$ Encontra-se no prelo capítulo de livro sintetizando os resultados de ambos os projetos. In: MASSARO, Paulo Roberto; OLIVEIRA, Renilson Santos (Org). Múltiplas veredas do ensino-aprendizagem de francês, língua estrangeira.

${ }^{9}$ GARCIA, Regina Leite. Múltiplas linguagens na escola. Rio de Janeiro: DP\&A, 2000; FERREIRA, Martins. Como usar a música na sala de aula. São Paulo: Contexto, 2001.

10 BUNZEN, Clecio; MENDONÇA, Marcia (Org). Múltiplas linguagens para o ensino médio. São Paulo: Parábola Editorial, 2013. 
metodológicos que visam contribuir - ainda que modestamente - para o aprofundamento da discussão a respeito do que se convencionou denominar Ensino Precoce (sic) de Línguas Estrangeiras.

Quando se fala do processo de ensino/aprendizagem de uma LE na infância, é comum se ouvir a expressão precoce. Contudo, como na língua portuguesa esse termo indica algo que acontece fora do tempo, antes da idade ou fora do momento oportuno, o uso de tal expressão pode supor que exista uma idade ideal para a entrada no mundo das línguas estrangeiras. O’Neil (1993:12-13) ${ }^{11}$ ao abordar esta questão, afirma que como o termo precoce possui infelizmente, de fato, uma certa ambiguidade, é preciso propor uma nomenclatura que defina de modo preciso, não a idade ideal, mas o conjunto de pressupostos teórico-metodológicos que justificam a inserção das LE antes do Ensino Fundamental. Assim, o autor sugere a sigla EPLV (Enseignement Pré-Secondaire des Langues Vivantes) ${ }^{12}$, visto que permite incluir tanto o ensino maternal quanto o primário.

Assim, preferimos adotar neste estudo o termo ensino/aprendizagem de LE para crianças a fim de evitar quaisquer mal-entendidos causados pela ambiguidade do termo precoce, pois acreditamos que o contato com uma LE desde os anos iniciais de vida é um ato educativo que transforma as crianças, fornecendo-lhes possibilidades de socialização por meio da descoberta de elementos linguístico-culturais diferenciados daqueles de sua língua materna, o que, certamente, trará consequências positivas para o seu desenvolvimento cognitivo.

Ainda que se reconheçam as influências de certos fatores biológicos sobre o desenvolvimento cognitivo, ao criar maneiras de se relacionar com o mundo, o ser humano, independentemente da fase da vida em que esteja, se encontra, com efeito, em contínuo processo de interação, ora com o outro, ora com o meio no qual está inserido.

${ }^{11}$ O'NEIL, Charmian. Les enfants et l'enseignement des langues étrangères. Coll. LAL. Paris: Hatier/Didier, 1993.

${ }^{12}$ Ensino Pré-secundário de Línguas Vivas. 
Sendo a busca pelo conhecimento, a criatividade, a curiosidade, a integração em sociedade características inerentes ao ser humano, seu processo de aprendizagem é igualmente contínuo, como corrobora Danvers (1992: 52) ${ }^{13}$ afirmando que as pessoas aprendem "por observação e por imitação; por repetição, por treino; por comunicações, por troca e confronto de argumentos, de experiências; por empenho, por interesse pessoal, individual...".

Embora saibamos que o processo de aprendizagem perdura por toda a vida, independentemente da idade do sujeito, focalizaremos aqui os elementos que o caracterizam nas fases iniciais da vida, ou seja, ao longo da infância.

As crianças precisam de espaço e de oportunidades para explorar o mundo a seu redor, conhecer a si mesmas, conhecer seu próprio corpo, habilidades e limites. Assim, o movimento corporal é parte essencial da experiência de aprendizagem na infância. $O$ simples movimento é uma das primeiras aquisições da criança em direção à autonomia e à formação de sua identidade e está fortemente ligado ao desenvolvimento da capacidade de controlar suas ações motoras, deslocando-se no espaço e manipulando objetos. Ao manusear objetos, a criança os transforma em brinquedos e brinca, satisfazendo grande parte de suas necessidades e interesses naturais.

A aprendizagem se dá em simples acontecimentos do cotidiano infantil: pisando na areia, na grama e através do manuseio de livros e da observação de figuras e formas. Sentir e descobrir o mundo ao seu redor são ações intrínsecas ao desenvolvimento infantil, sobretudo por intermédio de brinquedos que estimulam a imaginação e de materiais que incentivam a expressão artística, o que os torna grandes motivadores da aprendizagem.

A criança desenvolve seu aprendizado simultaneamente aos seus níveis emocionais, físicos, de pensamento e de linguagem, e é assim que, por volta dos três meses de idade, a

${ }^{13}$ DANVERS, Francis. $\mathbf{5 0 0}$ mots clefs pour l'éducation et la formation tout au long de la vie. Villeneuve d'Ascq: Presses Universitaires du Septentrion, 1992. 
criança tem suas primeiras “conversas” com a mãe. Segundo Gaonac'h (2006:33) ${ }^{14}$, alguns autores consideram que essas interações possibilitam a aquisição de elementos da linguagem e também as características estruturais das línguas.

Sabemos que falar de aprendizagem passa obrigatoriamente pela questão da linguagem; porém, mesmo não desconhecendo as teorias de aquisição da linguagem levantadas por Bruner, Skinner e Chomsky não é objetivo desta dissertação desenvolver longa discussão sobre este tema específico. Destacaremos apenas o que consideramos pertinente ao estudo em tela, ou seja, as possíveis relações entre a aquisição da língua materna (LM) e a aquisição-aprendizagem da língua estrangeira pela criança.

O modo de aprendizagem da LE está ligado ao modo de aquisição da LM, na medida em que um indivíduo dá sentidos às coisas que lhe são apresentadas a partir do ambiente no qual ele se encontra e de sua história. Consequentemente, tudo o que ele aprende é indissociável daquilo que ele já sabia. Porém, Gaonac'h argumenta que em contrapartida, "essa nova aprendizagem [a da língua estrangeira] ocasionaria potencialmente novas aquisições no domínio 'da língua' em geral que, por sua vez, poderiam ter consequências positivas sobre o domínio da língua materna." ${ }^{15}$ (GAONAC'H, 2006: 108).

A descoberta da nova língua faz com que as crianças testem hipóteses de compreensão, exigindo-lhes esforços, já que tanto linguística como culturalmente, as crianças se deparam com um conhecimento até então desconhecido. Para Gaonac'h (2006: 109), isso leva as crianças a terem uma experiência linguística que não pode acontecer de outra maneira; em outras palavras, o ensino de LE às crianças tem um papel de gatilho para outras aquisições linguísticas gerais. Sendo assim, quando tratamos do ensino de LE para crianças, o que está em jogo não é somente a aprendizagem da LE em si, mas as

\footnotetext{
${ }^{14}$ GAONAC'H, Daniel. L'apprentissage précoce d'une langue étrangère. Paris: Hachette, 2006.

${ }^{15}$ «Ce nouvel apprentissage est susceptible d'apporter des acquisitions nouvelles, dans le domaine de 'la langue' en général, qui puissent avoir des conséquences positives sur la maîtrise de la langue maternelle.»
} 
interferências dessa experiência na maneira da criança aprender de um modo geral, ver o mundo e se ver no mundo.

Ao focalizar o ensino de LE para crianças, é mister considerar o contexto no qual se encontra inserido do ponto de vista legislativo, institucional e curricular, visto que os professores se deparam com inúmeras coerções, tanto no que se refere à inserção de outras línguas estrangeiras, que não o Inglês na escola, quanto das Artes, o que formata, de uma certa forma, sua ação didática.

A legislação brasileira conta com apenas três documentos sobre o ensino de línguas estrangeiras no país: a LDB (Lei de Diretrizes de Base da Educação Nacional) ${ }^{16}$, os Parâmetros Curriculares Nacionais ${ }^{17}$ e o Referencial Curricular Nacional para a Educação Infantil ${ }^{18}$.

A LDB de 1996 legitima a inclusão das línguas estrangeiras nos currículos escolares apenas para o Ensino Fundamental e Médio conforme pode ser visto no artigo 26 deste documento:

§ 5‥ Na parte diversificada do currículo será incluído, obrigatoriamente, a partir da quinta série, o ensino de pelo menos uma língua estrangeira moderna, cuja escolha ficará a cargo da comunidade escolar, dentro das possibilidades da instituição. (BRASIL, 1996)

Os Parâmetros Curriculares Nacionais de 1998, em conformidade com a LDB, ditam que apenas as crianças com mais de 11 anos (ou seja, nos anos finais do Ensino Fundamental) terão acesso à LE no âmbito escolar. Constata-se, outrossim,que a língua majoritariamente oferecida nas escolas é a inglesa apesar das determinações mais recentes

\footnotetext{
${ }^{16}$ BRASIL. Lei no 9.394, de 20 de dezembro de 1996. Estabelece as diretrizes e bases da educação nacional. Diário Oficial da União. Brasília, DF, 23 dez. 1996.

17 BRASIL. Secretaria de Educação Fundamental. Parâmetros Curriculares Nacionais: arte. Brasília: MEC, 1997.

18 BRASIL. Ministério da Educação e do Desporto. Secretaria de Educação Fundamental. Referencial Curricular Nacional para a Educação Infantil / Ministério da Educação e do Desporto, Secretaria de Educação Fundamental. - Brasília: MEC/SEF, 1998.
} 
que incluem igualmente língua espanhola, seja no fim do Ensino Fundamental, seja no Ensino Médio.

Esta realidade nos faz retomar a ideia de que o uso do termo precoce, segundo O’Neil, contribuiu para um falso entendimento de que o ensino de LE na infância possui um caráter excepcional, ainda que o contato com as LE, como bem o mostra Favard (1993a, apud O'Neil, 1993: 129-130), possua “objetivos educativos gerais de ordem comportamental (autoconfiança, gosto pelo risco, curiosidade, etc.), cultural (a sensibilidade às diferenças culturais), cognitivo (o despertar da consciência linguística)". ${ }^{19}$

Parte integrante da série de documentos que formam os Parâmetros Curriculares Nacionais, o Referencial Curricular Nacional para a Educação Infantil foi concebido para servir de guia de reflexão sobre os objetivos, conteúdos e orientações didáticas para profissionais que atuam especificamente na Educação Infantil. Tendo como finalidade propiciar às crianças matriculadas em instituições de ensino o acesso e a ampliação dos conhecimentos da realidade social e cultural, o documento aponta metas de qualidade de ensino que contribuiriam para o desenvolvimento cognitivo integral da criança.

Este documento, ao longo de seu $2^{\circ}$ volume, traz uma importante ressignificação do termo linguagem; antes compreendido apenas como referências à escrita e à oralidade, o termo passa a ser utilizado no plural, se referindo assim tanto às linguagens verbais quanto às não verbais. Em outras palavras, o ensino para crianças deve englobar música, dança, movimento corporal, escultura, pintura, fotografia, teatro, cinema, dentre outros. Estas múltiplas linguagens passam, portanto, a ser aliadas obrigatórias na educação infantil.

Evidentemente em estrita coerência com os Parâmetros Curriculares Nacionais, o Referencial Curricular Nacional para a Educação Infantil ignora, por outro lado, a inserção de LE no currículo.

19 «Objectifs éducatifs généraux d’ordre comportemental (confiance en soi, goût du risque, curiosité, etc.), culture (la sensibilité aux différences culturelles), cognitif (l'éveil de la conscience linguistique). ” 
Além de dificuldades causadas pela total falta de amparo legal, vale ressaltar igualmente as coerções didáticas às quais são confrontados os professores atuantes em sala de aula de LE para crianças. Observam-se, primeiramente, profundas lacunas nos programas dos Cursos de Licenciatura em Letras - Línguas Estrangeiras; suas disciplinas obrigatórias tendem a fornecer subsídios teóricos e metodológicos restritos ao Ensino Fundamental e Médio $^{20}$ - quiçá transferíveis a escolas de línguas - sendo que o tópico "estratégias de ensino" raramente abrange as especificidades do público infantil.

Em segundo lugar, raríssimas são as editoras (mesmo estrangeiras) que dedicam parte de suas coleções especificamente a livros e outros materiais didáticos de LE destinados a crianças em fase de aquisição da escrita. Por conseguinte, a busca por recursos para o ensino de uma língua estrangeira neste contexto se torna tarefa árdua e extremamente dependente da criatividade (não raro solitária) do sujeito-professor, de sua experiência gradativamente adquirida no exercício da profissão, bem como do diálogo com especialistas em Pedagogia atuantes na mesma escola.

Apoiando-nos, por um lado, no Referencial Curricular Nacional para a Educação Infantil e, por outro, concordando com a afirmação de Gilles Brougère $(1998)^{21}$, segundo a qual, a expressão da criatividade através da linguagem será maior quando ela estiver intimamente relacionada com a Ludicidade e a Arte, discutiremos neste trabalho atividades didáticas caracterizadas pela ludicidade e pela interveniência de múltiplas linguagens para o ensino de Francês Língua Estrangeira destinado a crianças em fase de aquisição da escrita, buscando em Vigotski ${ }^{22}$ elementos teóricos que subsidiam seu foco principal: a mediação, instaurada por um agente lúdico configurado por um fantoche de gênero feminino.

\footnotetext{
${ }^{20}$ Conteúdos que são, aliás, extremamente generalizantes na maioria das vezes.

${ }^{21}$ Esta mesma informação pode ser encontrada em BROUGÈRE, Gilles. Jogo e educação. Porto Alegre: Artes Médicas, 1998 e BROUGËRE, Gilles. A criança e a cultura lúdica. In: Kishimoto, Tizuko Morchida (org). O brincar e suas teorias. São Paulo: Pioneira, 1998, p.19-32.

22 Optamos em padronizar a grafia Lev Semenovitch Vigotski no corpo da dissertação de mestrado e, ao mesmo tempo, manter as outras grafias existentes nas referências bibliográficas em respeito aos respectivos autores e tradutores.
} 


\section{Objetivos e perguntas de pesquisa}

Esta pesquisa tem por objetivo geral investigar a interveniência do agente mediador no processo de apropriação da língua francesa por crianças em fase de aquisição da escrita. Mais especificamente, estamos interessados em analisar as atitudes dos alunos com a língua estrangeira quando se encontram na presença e na ausência do agente mediador, bem como examinar o grau de motivação das crianças com a língua estrangeira e as atividades propostas na presença do agente mediador. Além disso, discutiremos a possível contribuição das atividades concebidas a partir de múltiplas linguagens subjacentes à capacidade linguageira infantil - para o desenvolvimento de inteligências plurais,

Em nossas análises, buscamos responder às seguintes perguntas de pesquisa:

1) Quais são as atitudes das crianças quando expostos ao uso de um agente mediador e suas decorrências para a aquisição de LE?

2) Como interagem as crianças durante atividades didáticas que articulam múltiplas linguagens? E suas decorrências para a aquisição de LE?

3) Como interagem as crianças durante atividades corporais em língua estrangeira? E suas decorrências para a aquisição de LE?

\section{Organização da dissertação}

Esta dissertação se divide em quatro partes, que se apresentam da seguinte forma:

\section{i) Fundamentação teórica}

No primeiro capítulo, apresentaremos as referências teóricas que fundamentaram nossa pesquisa. Em primeiro lugar, sob a luz de Lev Vigotski, Jean Piaget e Howard Gardner, discutiremos o papel da mediação, do corpo e das inteligências plurais no processo de aprendizagem infantil, refletindo também, sobre seus desdobramentos no desenvolvimento da criança. No segundo capítulo, discorreremos sobre o lúdico e a 
corporalização da língua estrangeira, ponderando a questão do jogo/da brincadeira e as múltiplas linguagens; e por fim, o jogo dramático infantil.

ii) Metodologia

Começaremos nosso capítulo de metodologia pela apresentação do contexto da pesquisa, esclarecendo a escolha da cidade onde foi realizada a coleta de dados. Em seguida, explicaremos a constituição do nosso corpus, apontando as instituições onde as oficinas de língua francesa foram oferecidas, os locais, a carga horária e o público alvo. Ainda nesta seção, abordaremos a questão da seleção e elaboração das atividades que compuseram as oficinas. Em seguida, explicitaremos os instrumentos de coleta de dados.

iii) Resultados da pesquisa

Neste capítulo, abordaremos os resultados encontrados no corpus de nossa pesquisa, discutindo-as sob a lente dos nossos pressupostos teóricos. Esta análise será realizada em duas partes. Na primeira parte falaremos sobre o agente mediador e suas aparições, descrevendo a reação das crianças e seus comportamentos. Na segunda parte, descreveremos os momentos em que, na sua ausência, houve evocação do agente mediador por parte das crianças, refletindo, paralelamente, sobre a interação das crianças durante as atividades didáticas que articularam múltiplas linguagens e durante atividades corporais em língua estrangeira.

Após os três capítulos, apresentaremos nossas considerações finais, nas quais faremos um balanço dos objetivos que foram alcançados e das dificuldades encontradas na realização desta pesquisa. Discorreremos também sobre as contribuições desta pesquisa e sobre os possíveis desdobramentos de nosso estudo. 


\section{FUNDAMENTAÇÃO TEÓRICA}




\subsection{A APRENDIZAGEM INFANTIL}

Ao desenvolver um estudo sobre a aprendizagem infantil, é incontornável levar em consideração, primeiramente, a psicologia do desenvolvimento proposta por Piaget a partir dos anos 1940.

Segundo Piaget, conforme o período de desenvolvimento em que a criança se encontre, ela possui sempre os mesmos conhecimentos, pois a aprendizagem é posterior ao desenvolvimento. Este autor propõe quatro períodos de desenvolvimento infantil: o período sensório-motor de 0 a 2 anos, o pré-operatório de 2 a 7 anos, o período das operações concretas dos 7 aos $11 / 12$ anos e o período das operações formais dos 11/12 anos em diante. Cada um desses períodos se caracteriza por diferentes formas de organização mental que permitem diferentes maneiras de interação do indivíduo com o meio, ou seja, com a realidade que o cerca.

No período sensório-motor ocorre o desenvolvimento inicial das coordenações e o início da diferenciação entre os objetos e entre o próprio corpo e os objetos. Nesse momento a inteligência se encontra nos sentidos (simbólico) e nas ações (motor) e se expande através dos deslocamentos do próprio corpo. Neste momento o bebê está trabalhando ativamente no sentido de formar uma noção de eu e assim se inicia um egocentrismo inconsciente e integral, até que os progressos da inteligência sensório-motora permitem a construção de um universo objetivo, onde o bebê irá explorar seu próprio corpo, conhecer os seus vários componentes, sentir emoções, estimular o ambiente social e ser estimulado por ele.

No período pré-operatório a criança inicia a capacidade de representar uma coisa por outra, ou seja, formar esquemas simbólicos a partir da linguagem. Com o início da linguagem, a criança se vê no meio de dois mundos novos: o mundo social e o das representações interiores. Durante esse período a criança continua bastante egocêntrica, 
devido a sua incapacidade de se afastar, de sair de suas percepções imediatas e pensar conceitualmente.

No que diz respeito especificamente à linguagem, é preciso ressaltar neste trabalho a concepção de Vigotski $(1997)^{23}$. Para este autor, a linguagem não se reduz a um sistema linguístico de estrutura abstrata, mas é constituinte do sujeito, considerando tanto seu aspecto funcional quanto psicológico. Para ele, a linguagem ocupa um lugar primordial no desenvolvimento das funções psicológicas superiores do ser humano (memória, pensamento e percepção), além de ser organizadora e planejadora do pensamento. A linguagem desempenha também um papel de mediadora dos seres humanos entre si e deles com o mundo e com isso, ela se torna um dos instrumentos básicos inventados pela humanidade para compreender e dominar seu ambiente e seu próprio comportamento, portanto, aprender continuamente.

Retomando Piaget, é preciso acrescentar ainda que no período pré-operatório, a criança já pode criar imagens mentais na ausência do objeto ou da ação e fazer uso do pensamento intuitivo; o período da fantasia, do faz de conta, do jogo simbólico começa a aparecer. Com a capacidade de formar imagens mentais, ela consegue transformar simples objetos em brinquedos, o que para Slade $(1978)^{24}$ caracteriza o jogo dramático infantil durante o qual "os objetos com os quais se brinca, mais do que a pessoa que está brincando, criam vida e exercem a atuação." (SLADE, 1978: 19).

O período operatório concreto se destaca pelo declínio do egocentrismo intelectual e segundo Piaget (1967: 42) ${ }^{25}$ como coincide com o começo da escolaridade da criança, marca uma modificação decisiva no desenvolvimento mental, pois elas estão desenvolvendo a capacidade de raciocinar sobre o mundo de uma maneira mais lógica. Nesse período a realidade passa a ser estruturada pela razão. A criança passa a ter um conhecimento real e

\footnotetext{
${ }^{23}$ VIGOTSKY, Lev Semenovitch. Pensée et langage. Trad. Françoise Sève. Paris: La Dispute, 1997.

${ }^{24}$ SLADE, Peter. O jogo dramático infantil. Trad.: Tatiana Belinky. São Paulo: 1978.

${ }^{25}$ PIAGET, Jean. Seis estudos de psicologia. Rio de Janeiro: Forense-Universitária, 1967.
} 
apropriado de objetos e situações da realidade e pensa antes de agir, ou seja, ela consegue solucionar mentalmente um problema. A capacidade de classificação, agrupamento, reversibilidade e linguagem socializada, ou seja, a capacidade de interação com o outro também se desenvolvem.

Por fim, no período das operações formais ocorre a transição para o modo adulto de pensar, ou seja, a capacidade de pensar sobre hipóteses e ideias abstratas e de compreender a lógica. Porém, esse período ainda é marcado pelo pensamento abstrato e pelo egocentrismo adolescente (o egocentrismo sensório-motor diminui e o metafísico encontra uma harmonia entre o pensamento formal e a realidade) como descreve Piaget (1967: 65) "É a idade metafísica por excelência: o eu é forte bastante para reconstruir o Universo e suficientemente grande para incorporá-lo.".

Posicionando-se em alguns aspectos contrariamente a Piaget, Vigotski defende a ideia de que não há estágios de desenvolvimento previstos e prontos dentro de cada um de nós, mas que o desenvolvimento acontece com o passar do tempo, sendo um processo que inter-relaciona a maturação do organismo, o contato com a cultura e as interações sociais. laço estreito entre desenvolvimento e aprendizagem, discutido por Vigotski em Pensée et langage, é analisado através de três abordagens diferentes e lança até hoje novos pressupostos para a compreensão desta inter-relação, bem como define o papel decisivo da educação para o desenvolvimento humano.

Na primeira abordagem apontada por Vigotski (1997), considera-se a aprendizagem e o desenvolvimento como independentes entre si. O desenvolvimento é o processo de maturação do sujeito segundo as leis naturais e a aprendizagem é puramente exterior às oportunidades geradas pelo processo de desenvolvimento. Priorizando o processo de desenvolvimento em detrimento da aprendizagem, esta concepção significaria que a aprendizagem não influencia o desenvolvimento. Nesta visão, a aprendizagem depende do surgimento de novos mecanismos e do aperfeiçoamento dos anteriores. 
Em uma segunda abordagem, Vigotski concebe aprendizagem e desenvolvimento como elementos naturais que não se separam, o que os tornaria similares. Alegando que "o desenvolvimento mental não é nada além da acumulação progressiva e contínua de reflexos condicionados" (VIGOTSKI, 1997: 337) ${ }^{26}$, ele declara ainda, que o desenvolvimento caminha ao lado da aprendizagem, ou seja, se desenvolvendo, a criança aprende e, aprendendo, a criança se desenvolve.

Já a terceira abordagem explicitada pelo estudioso vem equilibrar os dois pontos de vista extremos das teorias anteriores. Afirmando haver uma interdependência entre esses dois processos, Vigotski se posiciona definitivamente e pondera que se, por um lado, o desenvolvimento pontual da criança em um determinado estágio é reconhecível, por outro, é fundamental que se leve em consideração na aprendizagem que existe um desenvolvimento potencial, que pode ser calculado a partir do que a criança é capaz de fazer, primeiramente com a ajuda de um adulto e o que conseguirá fazer sozinha mais tarde.

Partindo da ideia de que a aprendizagem precede o desenvolvimento, Vigotski formula o conceito de zona de desenvolvimento proximal $(Z D P)^{27}$ para explicar essa influente correlação entre aprendizagem e desenvolvimento. Segundo esse conceito, devemos considerar dois níveis de desenvolvimento: o primeiro nível se refere ao desenvolvimento efetivo ou real, que é o já realizado, ou seja, o que a criança já é capaz de fazer. O segundo nível se trata do desenvolvimento potencial, ou seja, o desenvolvimento que está em via de se efetivar, que ainda não é parte do repertório próprio da criança. $\mathrm{O}$ aumento da zona de desenvolvimento potencial ocorre à medida que há uma intencionalidade para realizá-la, ou seja, por meio da aprendizagem.

Vale ressaltar que segundo a teoria vigotskiana, o desenvolvimento cognitivo só se efetiva no meio social e é nele que a criança realiza a apropriação dos comportamentos

\footnotetext{
26 «Le développement mental n'est rien d'autre qu'une accumulation progressive et continue de réflexes conditionnés. »

27 Adotamos o termo mais frequente, embora certos autores tenham questionado o uso do termo proximal. Devido às diversas traduções da obra, outros termos podem ser usados, como Zona de Desenvolvimento Iminente (ZDI).
} 
humanos. Logo, a interação entre os indivíduos possibilita a geração de novas experiências e aquisição de conhecimento. Essa experiência social que é a aprendizagem deve, então, acontecer dentro da zona de desenvolvimento proximal, que seria a distância existente entre aquilo que o sujeito já sabe, seu conhecimento real, e aquilo que o sujeito possui potencialidade para aprender, seu conhecimento potencial.

Tanto Piaget como Vigotski concordam que há uma distinção entre aprendizagem e desenvolvimento. Porém, para Piaget, os processos de desenvolvimento seriam independentes da aprendizagem, pois a antecedem, ao passo que Vigotski propõe que estes processos são indissociáveis, visto que o acesso do homem ao conhecimento, não é direto, ele é mediado. O papel do agente externo é, assim, de suma importância, pois sem a sua intervenção não há desenvolvimento, como corrobora Friedrich (2012: 114) ${ }^{28}$ : "o conhecimento não é dado nem adquirido, ele é mostrado, acentuado, demonstrado pelo professor e, a partir dessas operações, ele é construído pela criança."

Considerando o afirmado pela autora, ponderamos que o professor pode assumir e exercer seu papel de mediador ao oferecer às crianças possibilidades de diálogo entre significados (emoções, expectativas, valores, etc.) através de diferentes meios como músicas, brincadeiras, dramatizações, jogos.

Vigotski considera, então, que a aprendizagem é mediada pela interação entre a linguagem e a ação, e pela utilização de instrumentos e signos. Os instrumentos são as ferramentas que servem para transformar os objetos ou o meio. Ao se colocar entre o homem e o mundo, eles expandem as possibilidades de modificação da natureza. A mediação cria, deste modo, possibilidades de reelaboração (recriação) da realidade e por isso é vista como central.

${ }^{28}$ FRIEDRICH, Janette. Lev Vigotski: mediação, aprendizagem e desenvolvimento: uma leitura filosófica e epistemológica. Trad. Anna Rachel Machado e Eliane Gouvêa Lousada. Campinas: Mercado de Letras, 2012. 
Em todo o estudo de Vigotski, o sujeito é pensamento essencial, considerado não somente como um produto de seu contexto social, mas também como um agente ativo da criação desse contexto.

A mediação caracteriza a relação desse sujeito com o mundo e com os outros. E é através desse processo que as funções psicológicas superiores, especificamente humanas se desenvolvem. As funções psicológicas superiores - em grandes linhas, a capacidade de planejar ações, conceber consequências para uma decisão, fantasiar objetos etc.-, estão ligadas às ações intencionais como planejamento, memória voluntária, imaginação.

Vigotski (1998: 73) ${ }^{29}$ esclarece que

$$
\begin{aligned}
& \text { o uso de meios artificiais - a transição para a atividade mediada - muda, } \\
& \text { fundamentalmente, todas as operações psicológicas, assim como o uso de } \\
& \text { instrumentos amplia de forma ilimitada a gama de atividades em cujo interior as } \\
& \text { novas funções psicológicas podem operar. }
\end{aligned}
$$

Nesse sentido, o desenvolvimento humano é sempre mediado por agentes culturais e nessa interação, de acordo com Vigotski, ocorre a apropriação dos objetos culturais, o que desencadeia o desenvolvimento. Nesta interação entre o homem e sua cultura, é preciso valorizar os inúmeros agentes mediadores da aprendizagem (não só o professor e a escola agentes privilegiados) no processo de ensino-aprendizagem, como a interação com outra criança ou com o educador, o jogo, o brinquedo que têm papéis fundamentais na construção do conhecimento.

Dedicando-se a estudar esses filtros entre o organismo e o meio, o autor acredita que no início da infância, explorar o ambiente é uma das maneiras mais poderosas que a criança tem à sua disposição para aprender. As possibilidades que o ambiente oferece ao indivíduo são essenciais para que este se constitua como sujeito lúcido e consciente, capaz, por sua vez, de alterar o meio em que vive.

${ }^{29}$ VYGOTSKY, Lev Semenovitch. A Formação Social da Mente. Trad. José Cipolla Neto, Luis S. M. Barreto e Solange C. Afeche. São Paulo: Martins Fontes, 1998. 
As contribuições de Piaget e Vigotski dão certamente pistas de reflexão valiosas ao ensino, devendo promover uma postura investigativa do professor para que promovendo o diálogo entre as duas concepções teóricas, use-as em prol da aprendizagem infantil.

Outra teoria que merece destaque para a reflexão subjacente a esta dissertação é a formulada por Gardner nos anos 1980: a Teoria das Inteligências Plurais. ${ }^{30}$ Opondo-se à concepção de inteligência extremamente simplista que havia sido desenvolvida pelo psicólogo Alfred Binet e pelo médico Theodore Simon no começo dos anos $1900^{31}$ - visto que por um lado priorizava, sobretudo, as competências linguística e lógico-matemática e por outro, a reduzia meramente a dados quantificáveis, Howard Gardner propõe uma visão da mente humana estruturada pela interação psico-cognitiva entre competências intelectuais, que ele também nomeia como inteligências, visto que para o autor "uma inteligência implica na capacidade de resolver problemas ou elaborar produtos que são importantes num determinado ambiente ou comunidade cultural" (GARDNER, 1995: 21) ${ }^{32}$, não podendo, portanto, ser quantificada.

O psicólogo construtivista e pesquisador em Cognição, Educação e Neurologia da Universidade de Harvard defende que embora se relacionem entre si, essas competências intelectuais são relativamente independentes; todos os indivíduos seriam, assim, capazes de desenvolver, em graus e em combinações variadas, pelo menos oito delas, as quais o autor nomeia como inteligências: linguística, musical, lógico-matemática, espacial, interpessoal, intrapessoal, naturalista e corporal-cinestésica.

\footnotetext{
${ }^{30}$ Embora em suas obras Gardner utilize o termo "inteligências múltiplas", para evitar a repetição do adjetivo "múltiplo" em nossa dissertação, optamos por utilizar "inteligências plurais", como também o faz a autora francesa Hélène Vanthier em sua obra L'enseignement aux enfants en classe de langue. Paris: CLE, 2009.

31 O psicólogo Alfred Binet e o médico Theodore Simon desenvolveram um teste que seria aplicado em crianças para diagnosticar as dificuldades e melhorar, por um lado, o ensino e, por outro, o desempenho escolar. Este teste começou a ser desenvolvido na França e ficou conhecido como Teste de Quociente de Inteligência (QI). Esse teste que tinha, até então, a função de auxiliar na adequação das estratégias de ensino para crianças com dificuldade de aprendizagem, após migrar para os Estados Unidos, foi aplicado em milhares de soldados durante a Primeira Guerra Mundial na tentativa de medir quantitativamente suas inteligências, avaliando basicamente a capacidade de dominar o raciocínio linguístico e lógico-matemático.

32 GARDNER, Howard. Inteligências múltiplas: a teoria na prática. Trad. Maria Adriana Veríssimo Veronese. Porto Alegre: Artes Médicas, 1995.
} 
Quanto à primeira inteligência, a linguística, Gardner afirma que é a "mais ampla e mais democraticamente compartilhada na espécie humana." (GARDNER, 1994: 61) ${ }^{33}$. Para o autor, esta inteligência consiste na capacidade de dominar a tétrade linguística, ou seja, a semântica, a fonologia, a sintaxe e a pragmática. Assim sendo, as pessoas com alto grau de desenvolvimento dessa competência podem explorar com facilidade a semântica, sabendo examinar o sentido das frases e textos; a fonologia possuindo sensibilidade aos sons das palavras; domínio da sintaxe, regras que governam a ordenação das palavras e suas inflexões e reconhecimento das funções pragmáticas, reconhecendo os diversos usos que se pode dar à linguagem através dos atos de fala.

Esta inteligência aparece geralmente a partir dos dois anos de idade e vai se definindo ao longo da vida. As crianças a manifestam pelo gosto de ouvir, ler e contar histórias, surpreendem pelo vocabulário que conhecem e utilizam, se interessam pela leitura e após o domínio da escrita, se interessam por jogos de palavras, rimas, trocadilhos, etc.

Os comportamentos mais frequentes são contar histórias, recitar pequenos poemas, repetir frases ou cantigas, etc. Nos adolescentes e adultos, nota-se a facilidade na comunicação, o alto grau de atenção e a facilidade em lidar com as expressões escrita e oral.

Gardner se preocupa em não definir esta competência como uma forma auditivo-oral de inteligência e ressalta que os surdos podem adquirir uma linguagem natural ou dominar um sistema gestual. Esta afirmação nos leva a refletir que a inteligência linguística não é apenas uma capacidade auditiva e oral apurada, mas que pode operar independentemente da fala.

A inteligência musical é a que surge mais cedo no indivíduo embora não saibamos o porquê, nem sua natureza. Segundo Gardner, população humana; [...] os indivíduos podem fazer seu encontro inicial com a música

${ }^{33}$ GARDNER, Howard. Estruturas da mente: A Teoria das Inteligências Múltiplas. Trad. Sandra Costa. Porto Alegre: Artmed, 1994. 
Ainda segundo o autor, todos os indivíduos são capazes de reconhecer algo da estrutura musical como uma mudança de ritmos e a diferença de tonalidades das vozes em um coral. Essa competência musical é caracterizada pela sensibilidade ao tom, ao ritmo, e ao timbre e pode se tornar uma capacidade em cantar, tocar instrumentos com as mãos, com as bocas, ler notações musicais, escutar gravações, ter prazer em observar danças e seus ritmos, etc.

Ela pode ser percebida nas crianças que se mostram sensíveis a sons e aos seus ambientes, motivam-se com instrumentos, batuques, ritmos e incorporam a música às suas vidas.

A audição certamente é um componente importante da música, mas para Gardner não é o essencial, pois sua organização rítmica, por exemplo, permite que indivíduos privados desta capacidade possam, pelo menos em parte, desfrutar de alguns aspectos da experiência musical.

A próxima inteligência é a lógico-matemática que representa a capacidade de dedução e observação. Pessoas com esse tipo de competência têm facilidade em lidar com a abstração. A primeira abstração com a qual elas lidam é a ideia de número e de que diferentes quantidades podem ser distinguidas umas das outras a partir desta premissa.

A criança pequena adquire seu conhecimento inicial e mais fundamental sobre o domínio lógico-matemático a partir do confronto, ordenação, manipulação de objetos. Muito influenciado por Piaget, Gardner também acredita que a criança, partindo de observações e objetos no mundo material, move-se em direção a sistemas cada vez mais abstratos e por isso a capacidade em calcular rapidamente está longe de ser central nesta competência e é, no máximo, uma vantagem acidental. Para ele, "é bem possível que a característica mais central e menos substituível do talento matemático seja a capacidade de manejar habilmente longas cadeias de raciocínio." (GARDNER, 1994: 108). 
As crianças com um elevado desenvolvimento dessa inteligência gostam de separar, classificar e organizar objetos e brinquedos, aprendem a calcular rapidamente e são excelentes em brincadeiras que envolvem lógica e estratégia.

Em seguida, a inteligência espacial está ligada ao mundo concreto, ao mundo dos objetos e a sua localização no mundo. É a capacidade de criar imagens mentais, comparar objetos em angulações, tamanhos e direções diferentes, mover mentalmente objetos no espaço e resolver problemas valendo-se da visualização. A inteligência espacial é indispensável para andar na rua e se localizar. Ela está muito presente nos artistas plásticos, engenheiros e arquitetos.

Esta competência se desenvolve através de um refinamento das percepções sensório-motoras, que permitem uma boa discriminação das cores, das formas, das texturas, das dimensões e das relações espaciais. Nas crianças, ela se apresenta pela facilidade em imaginar e entender mapas, tabelas, horários e esquemas. Parecem pensar e agir através de imagens visuais e gostam de imaginar lugares e situações.

Segundo Gardner (1994: 135), as características centrais desta inteligência são "perceber o mundo visual com precisão, efetuar transformações e modificações sobre as percepções iniciais e ser capaz de recriar aspectos da experiência visual, mesmo na ausência de estímulos físicos relevantes."

Pessoas com alto desenvolvimento da inteligência interpessoal geralmente gostam de trabalhar em grupo e de cooperar, têm muitos amigos e lidam muito bem com as diversas situações sociais, sabendo adequar-se. Elas têm facilidade de comunicação e dominam o discurso retórico, sabendo mediar disputas.

Enquanto crianças, gostam de atividades em grupo e geralmente são escolhidas para liderar grupos, comandar atividades, ou seja, para ocupar o papel de liderança. Fazem amizade com extrema facilidade e não gostam de ficar sozinhas. 
Altamente sofisticada em líderes religiosos ou políticos, professores e terapeutas, a inteligência interpessoal é a capacidade de compreender as emoções alheias e agir corretamente diante das atitudes das outras pessoas.

Para Gardner (1995: 27) embora todas essas características estejam presentes nos indivíduos com inteligência interpessoal, eles possuem a "capacidade nuclear de perceber distinções entre os outros; em especial, contrastes em seus estados de ânimo, temperamentos, motivações e intenções."

A inteligência intrapessoal é considerada a mais singular de todas e consiste na habilidade de valer-se de seus sentimentos na resolução de seus problemas. As pessoas que desenvolveram esta competência tendem a ser reservadas e automotivadas. São conscientes das próprias potencialidades, fraquezas e valores. As crianças que têm esta inteligência mais desenvolvida são intuitivas, tendo um sentido bastante autocrítico, gostam de aprender e de aperfeiçoar-se.

Nos adultos, percebe-se que eles costumam gerenciar sua própria aprendizagem e não alimentam expectativas. Com grande poder de autoconhecimento, eles têm "acesso ao sentimento da própria vida, à gama das próprias emoções, à capacidade de discriminar essas emoções e eventualmente rotulá-las e utilizá-las como uma maneira de entender e orientar o próprio comportamento. " (GARDNER, 1995: 28).

Uma sétima inteligência é a naturalista. Ela se refere à capacidade que se desenvolve em pessoas de grande criatividade, consistindo na sensibilidade em descobrir a natureza de forma integral e se envolver com profunda empatia com o mundo vegetal e animal. Essa competência geralmente é aplicada produtivamente na agricultura ou nas ciências biológicas. Embora a habilidade de apreciar a vida ao ar livre ou de sentir-se confortável junto à natureza sejam importantes aspectos dessa inteligência, ela tem sido caracterizada mais como uma capacidade para discernir, identificar e classificar plantas e animais, do que uma habilidade de conviver com a natureza. Essa inteligência também é conhecida como inteligência biológica ou ecológica, e manifesta-se em diferentes níveis. 
Sempre presentes nos jardineiros, paisagistas, amantes ambientalistas, geógrafos, zoólogos, veterinários etc. Nas crianças podemos notar o interesse por animais, plantas e pela vida rural.

Por último, nos referimos à inteligência corporal-cinestésica, que ocupa posição de destaque neste estudo. Essa competência pode ser observada desde os anos iniciais e seu desenvolvimento na infância é claramente perceptível através da progressão do mais simples reflexo a atos comportamentais mais complexos. Esta inteligência constitui o controle do movimento corporal, em usar o próprio corpo para expressar uma emoção (como na dança), jogar um jogo (esporte), ou criar um novo produto (planejamento de uma invenção).

É a capacidade que a criança tem de controlar e utilizar o corpo, corpo este que se movimenta no espaço. Elas aprendem melhor fazendo e experimentando do que ouvindo.

Esta competência envolve o uso hábil dos movimentos corporais. Estes movimentos tanto podem ser do corpo inteiro para representar determinado tipo de atividade - como as atividades dos nadadores e dos dançarinos que possuem domínio aguçado de seus movimentos - quanto podem se tratar do movimento motor fino - para manipular, organizar e transformar objetos como o do mímico que emprega com perfeição os movimentos e as expressões faciais para representar ações e o dos artesãos que pintam, esculpem, tecem com perfeição, dos instrumentistas que manipulam os instrumentos com perfeito controle motor.

A noção de cultura é básica para a teoria das Inteligências Plurais. Como sua definição sugere a capacidade em resolver problemas que são significativos em um ou mais ambientes culturais, Gardner sugere que algumas dessas aptidões só se desenvolvem porque são valorizados pelo ambiente em que a criança está inserida, assim como Vigotski que sustenta a ideia de que o meio no qual a criança interage exerce influência direta sobre seu desenvolvimento cognitivo, físico-motor e afetivo. 
O desenvolvimento das inteligências no indivíduo tem uma trajetória que começa com a capacidade pura de padronizar. Em seguida, o aparecimento da competência simbólica é visto nos bebês quando eles começam a perceber o mundo ao seu redor. Nesta fase, os bebês apresentam capacidade de processar diferentes informações, eles já possuem, no entanto, o potencial para desenvolver sistemas simbólicos, como também identificara Piaget no período sensório-motor.

Com a progressão do desenvolvimento infantil, a inteligência é vista por meio desse sistema simbólico: "a linguagem é encontrada através de frases e histórias, a música através das canções, o entendimento espacial através de desenhos, a corporal-cinestésica através dos gestos ou dança e assim por diante" (Gardner, 1995: 31). ${ }^{34}$

No estágio seguinte, a criança prossegue para adquirir níveis mais altos de desenvoltura no desenvolvimento das inteligências e seus respectivos sistemas simbólicos e aprendem o que Gardner chama de sistema notacional, ou seja, a grafia dos sistemas (a escrita, os símbolos matemáticos, a música escrita etc.). Nesta fase, os vários aspectos da cultura têm impacto considerável sobre o desenvolvimento da criança, uma vez que ela aprimorará os sistemas simbólicos que demonstrem ter maior eficácia no desempenho de atividades valorizadas pelo grupo cultural. Assim, uma cultura que valoriza a música terá um maior número de pessoas que atingirão uma produção musical de alto nível, por exemplo.

Considerando as crianças agentes ativos na formação de seu conhecimento, a teoria construtivista contemporânea nos leva a compreender que as competências cognitivas são bem mais distintas e peculiares do que se acreditava e, portanto, a aprendizagem deve ser promovida por meio de atividades mais promissoras de construção de conhecimento.

Quando falamos de uma educação global e integral, temos que pensar na pessoa que se constrói a partir de todas as possibilidades que ela tem. No âmbito educacional, a

\footnotetext{
${ }^{34}$ Vale ressaltar aqui o trabalho de Trajano (2008) que demostra em que medida a proposta pedagógica de educação artística projetada por Gardner é similar à dos $\mathrm{PCN}^{34}$ e quais seriam os benefícios de um trabalho artístico sensibilizador nessa faixa etária para o desenvolvimento da personalidade do indivíduo.
} 
consideração das inteligências plurais contribui para um melhor entendimento de que cada criança tem sua maneira ímpar de aprender e possui formas cognitivas diferenciadas.

Em suma, as relações entre desenvolvimento e aprendizagem infantil aqui discutidos pelas perspectivas de Piaget e de Vigotski, bem como o conceito vigotskiano de mediação e por fim, a Teoria das Inteligências Plurais de Gardner, apontam para a necessidade de transformação da escola, para que esta se torne mais convergente à questão da formação integral de todos os indivíduos, colaborando para a construção da autonomia de pensamento e de ação do indivíduo, estendendo, assim, sua chance de participação social. 


\subsection{O LÚDICO E A CORPORALIZAÇÃO DA LÍNGUA ESTRANGEIRA}

\subsubsection{Jogo, brincadeira, múltiplas linguagens e mediação}

Diversos teóricos da educação e da psicologia observaram o jogo infantil e refletiram sobre o desenvolvimento da criança através dele, provando que, a aprendizagem está diretamente ligada ao corpo, pois é agindo sobre o mundo que ela aprende sobre ele.

Do ponto de vista vigotskiano, ao brincar, a criança desenvolve a capacidade de usar os elementos conforme o universo simbólico da brincadeira e assim modificar a função de um elemento para criar o efeito que deseja. Para Vigotski (1998) o brincar é a etapa mais importante da vida infantil e permite a criação da situação imaginária, o desenvolvimento da representação e do símbolo.

Já segundo Piaget (1990) o brincar seria um fator de desenvolvimento cognitivo e também uma forma de adequação ao mundo externo, sendo, então, um aspecto ativo e importante do desenvolvimento intelectual infantil. Para o autor, a representação de fenômenos externos não influencia na aquisição de conhecimento, mas sim a interação da criança com o meio em que vive. $E$ os processos de acomodação e assimilação é que permitem que a realidade presenciada se transforme em conhecimento. No jogo, há uma predominância da assimilação e, assim, a criança compreende o mundo à sua maneira.

As palavras lúdico e jogo são amplamente discutidas em diversas áreas das ciências humanas (pedagogia, antropologia, sociologia, psicologia, didática, dentre outras), o que nos mostra incessantes tentativas de classificar e diferenciá-las. Neste trabalho, as tratamos como sinônimas, assim como Brougère (1998: 14-15) $)^{35}$ que afirma que em uma rápida análise lexical a palavra jogo tem três significações: ela é sinônima de atividade lúdica, visto que se trata de uma situação onde há pessoas jogando; é também uma estrutura, um sistema de regras que existe independentemente de haver pessoas jogando - como o

${ }^{35}$ BROUGÈRE, Gilles. Jogo e educação. Porto Alegre: Artes Médicas, 1998. 
futebol, o xadrez, etc. -; e, é também, material de jogo, que pode, em alguns casos, ser associado à palavra brinquedo.

Huizinga $(1971)^{36}$, assumindo que a tarefa de definir "jogo" é árdua e complexa devido a seus múltiplos entendimentos e significações nas diferentes culturas, ressalta que a função do jogo é o que importa, visto que ela prevalece a mesma em qualquer sociedade e cultura.

Para esta relação entre jogo e cultura, Brougère $(2004)^{37}$ explica que a criança aprende a brincar de acordo com o seu meio e isso faz com que ela aprenda a cultura na qual está inserida. As culturas lúdicas são diferentes de país para país devido aos costumes próprios, mas elas também podem divergir de acordo com o meio social, a cidade e, claro, o gênero da criança. Ao brincar, a criança produz sua própria cultura lúdica, e é todo o conjunto de suas experiências, inclusive as brincadeiras enquanto bebê que vão fazê-la constituir essa cultura. Assim, o jogo e a cultura estão profundamente ligados, já que o jogo produz uma cultura, cultura esta que ele precisa para existir.

Na essência do jogo, encontramos a primeira de suas características fundamentais: o fato de ser livre e voluntário. Os adultos podem facilmente dispensar o jogo, considerandoo algo supérfluo, pois ele "só se torna uma necessidade urgente na medida em que o prazer por ele provocado o transforma numa necessidade" (HUIZINGA, 1971:11).

A segunda característica é que o jogo não é vida real. A criança reconhece seus momentos de imaginação e de faz de conta e os diferencia da realidade. Mas não é por isso que o jogo deixa de ser uma atividade séria sendo "capaz, a qualquer momento, de absorver inteiramente o jogador." (Idem, p. 11).

Situado fora do mecanismo de satisfação imediata das necessidades e desejos, o jogo é atividade temporária que encontra fim em si mesmo e se realiza almejando a

\footnotetext{
${ }^{36}$ HUIZINGA, Johan. Homo Ludens. São Paulo: Perspectiva, 1971.

${ }^{37}$ BROUGÈRE, Gilles. Brinquedo e companhia. São Paulo: Cortez, 2004.
} 
satisfação que consiste na própria realização. $O$ fato de distinguir-se da vida comum e se apresentar como um intervalo, uma pausa constitui sua terceira característica: o isolamento, a limitação. Seu início e fim são bem definidos, mas nada impede sua repetição, o que caracteriza uma de suas qualidades fundamentais.

A quarta e última característica fundamental do jogo é o fato dele "criar ordem e ser ordem" (Idem, p. 13). O jogo "introduz na confusão da vida e na imperfeição do mundo uma perfeição temporária e limitada, exige uma ordem suprema e absoluta", ele, assim como o agente mediador, tem o poder de enfeitiçar, fascinar e cativar, criando um ambiente deslocado da realidade mas, ao mesmo tempo, pertencente a ela.

Ainda para Huizinga (1971:14) o jogador que aceita entrar no jogo, aceita suas regras que são absolutas e indiscutíveis. Sua quebra repercute no fim do jogo. Essas regras podem ser de diferentes naturezas como em um jogo de cartas ou de xadrez, onde há lei que regem movimentos e ações, mas também há situações lúdicas onde a regra do jogo é o faz de conta, como as situações de imaginação infantil que recriam uma escola ou um supermercado; neste caso, é a fuga do personagem e o não acompanhamento da cena imaginária que fundam a infração.

Caillois (1967:75) ${ }^{38}$ corrobora com Huizinga (1971) ao afirmar que as regras são inseparáveis do jogo e "são elas que o transformam em instrumento de cultura fecundo e decisivo." ${ }^{39}$. Mesmo admitindo que a variedade de jogos dificulta a tarefa de classificá-los em um pequeno número de categorias, Caillois propõem 4 classificações gerais: Agôn, Alea, Mimicry e llinx.

Agôn é a primeira das categorias e inclui todos os jogos de competição, sejam eles de caráter físico como a rapidez, a força ou de caráter mental, como a memória e o raciocínio. Esses jogos podem ser disputados entre duplas ou equipes (jogos de futebol, tênis, jogo da memória, damas) ou em número não determinado (corridas, atletismo).

\footnotetext{
${ }^{38}$ CAILLOIS, R. Les jeux et les hommes. Paris: Gallimard, 1967.

39 " Ce sont elles qui le transforment en instrument de culture fécond et décisif.»
} 
Nesses jogos a motivação de cada participante é ter sua excelência reconhecida, o que os torna exigentes nos quesitos atenção, prática, esforço e vontade de vencer e exige disciplina e perseverança. "O agôn se apresenta como a forma pura do mérito pessoal e serve para manifestá-Io."40. (CAILLOIS, 1967: 53)

Alea é a segunda categoria apresentada e representa os jogos de azar. O jogador não utiliza suas qualidades e inteligência, ele é totalmente passivo. Nesses jogos o resultado não depende do jogador, pois ganhar significa vencer o adversário e o destino. Esta categoria é o exato oposto do agôn já que aqui o jogador é um mero espectador à espera do resultado. Ela despreza o trabalho, a paciência, a habilidade e o treino.

Muitos jogos podem ser uma combinação de agôn e alea, como a maioria dos jogos de carta, pois essas duas categorias contem atitudes opostas mas obedecem a uma mesma lei que a é criação de situações artificiais de igualdade entre os jogadores.

A terceira categoria é o mimicry. Nela "qualquer jogo supõe o aceite temporário, se não de uma ilusão, pelo menos de um universo fechado, convencional e, sob certa perspectiva, fictício."41 (Idem, p. 61). O princípio é o de acreditar, se convencer ou convencer os outros de que somos outros que não nós mesmos. O prazer está em ser outro e não em enganar o espectador. Como estão envolvidas aqui a atividade, a imaginação e a interpretação, todas as artes do espetáculo como a dança, o teatro ou as imitações infantis, fantasias e mímicas fazem parte do mimicry.

Bem o sabemos que em um ambiente de sala de aula de língua estrangeira vivemos, criamos (professores e alunos) identidades fictícias. Não excluindo o público adulto, ressaltaremos aqui as crianças que criam e (re)inventam personagens e situações a todo momento. Imaginar faz parte da rotina infantil e estimular as situações de mimicry torna a sala de aula um espaço favorável para a brincadeira, logo para a aprendizagem.

\footnotetext{
${ }^{40}$ L'agôn se présente comme la forme pure du mérite personnel et sert à le manifester.

41 « Tout jeu suppose l'acceptation temporaire, sinon d'une illusion [...], du moins d'un univers clos, conventionnel et, à certains égards, fictif. »
} 
A quarta e última categoria é Ilinx. Reunindo todos os jogos de vertigem, que podem ser tanto físicos quanto morais, englobam as acrobacias, o alpinismo, esportes radicais, ou mesmo o escorregador e o carrossel.

O essencial aqui está na continuação da angústia específica, do pânico momentâneo que define o termo vertigem e incontestáveis aspectos do jogo que estão associados: liberdade de aceitar ou recusar o teste, limites rígidos e imutáveis, separação do resto e da realidade. (IDEM, p. 75) ${ }^{42}$

Considerando as teorias apresentadas, o jogo faz parte da cultura e é algo livre e incerto. "As crianças e os animais brincam porque gostam de brincar, e é precisamente em tal fato que reside sua liberdade" (HUIZINGA, 1971: 10). Se o jogo não pode se constituir enquanto uma tarefa para manter sua natureza livre, como pensá-lo como constituinte do processo de ensino/aprendizagem de uma língua estrangeira?

Kishimoto (2012: 48) afirma que no contexto educacional, "o ponto de partida é o lúdico porque o interesse da criança mobiliza a mente infantil." e Huizinga (1971: 10) explica que em relação à criança, esse caráter de liberdade do jogo poderia ser questionado já que elas são levadas "ao jogo pela força do seu instinto e pela necessidade de desenvolverem suas faculdades físicas e seletivas". Portanto, se no processo de ensino/aprendizagem, as atividades forem vistas como fonte de prazer, almejadas e apreciadas, mantém- se assim, o caráter de jogo.

Piaget $(1990)^{43}$ explica ainda que no jogo e na arte há uma ilusão voluntária consciente, ou seja, a imaginação representa o objetivo lúdico como verdadeiro e o prazer de ser nos lembra que somos nós mesmos quem criamos essa ilusão. Esse simbolismo "oferece à criança a linguagem pessoal viva e dinâmica, indispensável para exprimir sua subjetividade intraduzível somente na linguagem coletiva" (PIAGET, 1990: 214).

\footnotetext{
42 L'essentiel ici réside dans la poursuite de ce désarroi spécifique, de cette panique momentanée qui définit le terme de vertige et des indubitables caractères de jeu qui s'y trouvent associés : liberté d'accepter ou de refuser l'épreuve, limites strictes et immuables, séparation d'avec le reste de la réalité.

43 PIAGET, J. A Formação do símbolo na criança: imitação, jogo e sonho, imagem e representações. $3^{\text {a }}$ ed. Rio de Janeiro: LTC, 1990.
} 
Considerar, então, o jogo como uma forma de diversão não é excluir seu papel educativo, é separar algumas formas de pensar essa questão em relação à criança, a suas características psicológicas e a seu desenvolvimento.

Vale ressaltar aqui que Vigotski (1998) compreende a mediação como processo cultural pela aprendizagem e é esse processo que caracteriza a relação do homem com o mundo e com outros homens, ou seja, a construção do conhecimento é uma interação mediada por várias relações, pois a mediação cria as possibilidades de reelaboração (recriação) da realidade.

Sendo assim e distinguindo os dois tipos de elementos mediadores propostos por Vigotski: os instrumentos e o signo, podemos considerar o jogo como um destes elementos, visto que o ser humano, enquanto sujeito do conhecimento, não tem acesso direto às coisas, mas sim um acesso mediado por meio de recortes do real realizados pelos sistemas simbólicos que possui e esses recortes do real podem ser feitos através de jogos e brincadeiras.

Porcher e Groux (1998: 90) ${ }^{44}$ afirmam que "brincando de aprender uma língua estrangeira, eles realmente a aprendem. ${ }^{\text {"35 }}$, logo, as atividades lúdicas podem ser de grande valia e o professor de língua estrangeira deve criar intencionalmente essas situações lúdicas em sala de aula.

Desta forma, um programa que vise o ensino de FLE para as crianças deve levar em conta as necessidades específicas da idade, sejam elas motoras ou afetivas, assim como os pontos de interesse, as capacidades e os processos de aprendizagem desse jovem público no momento de pensar e selecionar atividades e jogos que integrarão o programa, pois como corrobora Garcia (2000: 96) "os fluxos lúdicos são fontes primárias de

\footnotetext{
${ }^{44}$ PORCHER, Louis, GROUX, Dominique. L'apprentissage précoce des langues. Paris: PUF, col. Que sais-je? 1998.

${ }^{45} \mathrm{En}$ jouant à apprendre une langue étrangère, ils l'apprennent vraiment.

${ }^{46}$ GARCIA, Regina Leite. Múltiplas linguagens na escola. Rio de Janeiro: DP\&A, 2000.
} 
aprendizagem. [...] Devemos lutar com todas as forças pelos direitos da criança à livre expressão dos seus próprios modos brincantes".

Desde o nascimento, as crianças já estão inseridas em contextos sociais diversos que Ihes apresentam sons, formas, aromas, cores, texturas, gestos, e diversas manifestações culturais e expressivas que integram o mundo ao seu redor. O contexto escolar deve, portanto, incorporar e incrementar essa riqueza de possibilidades, não excluílas como vemos em alguns estabelecimentos.

As crianças, altamente desejosas de se manifestar expressivamente (por meio de desenhos, pinturas, esculturas, dança), são capazes de utilizar diferentes linguagens; porém, não raramente, são reprimidas nos contextos escolares ou pelos pais que estão condicionados a pensar nas linguagens sempre relacionadas à fala ou à escrita e deixam de pensá-las adjuntas ao movimento, ao desenho, à dramatização, à brincadeira, à fotografia, à música, à dança, ao gesto, etc.

Para Garcia, (2000: 55) é, infelizmente, na escola primária que

\begin{abstract}
a criança aprende a não ser ela mesma, quando vê que não pode competir com os esforços da escola que com seus programas funcionam com o objetivo de fabricar toda a tristeza e estrangular o artista que habita cada criança
\end{abstract}

As múltiplas linguagens são ações naturais do universo infantil e estimular o seu desenvolvimento neste ambiente de ensino/aprendizagem significa auxiliar o completo desenvolvimento infantil.

Sendo assim, falar das múltiplas linguagens no contexto infantil, significa falar de elementos que revelam as características da linguagem própria da criança, como por exemplo: ludicidade, simbolismo, imaginação, representação. Recorrer às linguagens artística, corporal, musical, oral, escrita, pictórica, dramática, como formas de estabelecer comunicação com o mundo é um direito que a criança tem e que o processo de ensino/aprendizagem deve assegurar. 
Indagamo-nos, então: o que são essas múltiplas linguagens e como incluí-las no currículo infantil? $\mathrm{Na}$ incapacidade de enumerar todas elas, destacamos as que foram abordadas neste estudo.

A linguagem plástica explorada por atividades como desenho e/ou pintura (traços, riscos, paisagens, pessoas, animais) pode ser realizada sobre diferentes suportes e com diversos materiais. Os desenhos são como um jogo onde há narrativas, imaginações, inventividade típicas de cada criança.

Os desenhos das crianças podem ser considerados como metáforas visuais, formas de explicar abstrações tais como o amor, a alegria, o futuro, ou ainda uma possibilidade de atribuir a uma coisa o nome de outra, com traços e formas, às vezes inusitados.

As crianças interpretam sua realidade em seus traços e cores. Sendo assim, podemos considerar seus desenhos como a sua maneira própria extra-verbal de expressar sentimentos, tais como alegria, amor, desejo. Estar com as crianças, observar, preparar junto com elas espaços privilegiados para se expressarem é, então, algo essencial e deve ser garantido tato na escola quanto nos cursos de língua estrangeira e no ambiente familiar.

Os diversos suportes para o desenho devem ser oferecidos à criança, com variedade de cores, texturas e formas de tamanhos diversos. Como instrumentos, além dos lápis de cor, canetas hidrocor, giz de cera, tintas variadas e porque não carvão e cacos de tijolos.

O papel não deve ser o único material a ser oferecido para as crianças; a pintura corporal é também um modo de exploração e interação, bem como o chão ou então, os tablets e computadores já inseridos na realidade dessa geração, que desde muito novos já sabem manusear tais equipamentos, mesmo sem conhecimento da escrita.

O desenvolvimento da linguagem escrita, segundo Vigotski (1998), se dá pela mudança do desenho de coisas, para o desenho de palavras. De fato, o segredo do ensino da linguagem escrita está atrelado à organização adequada dessa transição. Uma vez dominado o princípio da linguagem escrita, a criança passa à etapa de aperfeiçoamento. 
Considerando o domínio de um complexo sistema de símbolos que é a linguagem escrita, Vigotski ressalta que sua aprendizagem não pode ser alcançada de forma externa e mecânica. Para ele, a escrita é o resultado das diversas experiências que a criança realiza durante sua infância, por meio dos gestos, brincadeiras, manipulações e pelo movimento do seu corpo, proporcionado pelas atividades envolvendo a dança e a música. Dessa forma, compreendemos que a escrita compõe-se nas mais diversas relações estabelecidas pela criança no decorrer das atividades que realiza.

Uma outra linguagem é a corporal. Esta é frequentemente expressada por meio de atividades lúdicas como os jogos e brincadeiras, mímicas, atividades de conscientização corporal, etc.

Todas as crianças podem se expressar com repertório que é próprio de seu corpo, criando coreografias, passos e movimentos próprios. Segundo Gardner (1994) o desenvolvimento e o contato com a linguagem corporal estimulam no indivíduo, áreas do cérebro que acentuam a percepção, aumentando a sensibilidade, o raciocínio, a concentração, memória e coordenação motora. O uso da linguagem corporal, logo, da inteligência corporal cinestésica é um elo integrador entre os aspectos motor, cognitivo, afetivo e social, pois a criança consegue compreender o mundo a sua volta quando vive experiências sensórias motoras, ou seja, interage com seu corpo e com o mundo que a cerca, e é então, que ela assimila conhecimento.

A linguagem fotográfica no cotidiano infantil, além de introduzir e motivar conversas sobre as transformações de sua história, de sua família, de amigos, passeios, festas, etc através do uso de um acervo pessoal, possibilita capturar imagens (por meio de máquinas fotográficas ou celulares) do meio escolar em que a criança está inserida e fazê-las observar e discutir o ambiente.

Segundo Garcia (2000: 33) a utilização da fotografia em sala de aula não deve "ser utilizada simplesmente como ferramenta de apoio, mas sim como elemento plural, também capaz de apontar questões de ordem pedagógica ou simplesmente despertar a 
curiosidade.". Esse recurso, poderia, então, compor uma galeria de fotos feita no contexto escolar, que retratam a hora do lanche, a formiga que anda no pátio, o movimento dos balanços e por registrar o cotidiano na perspectiva da criança, consideram os detalhes pouco explorados e conhecidos por todos.

Destacamos, por fim, a linguagem teatral. O contato com esta linguagem permite e estimula o desenvolvimento, a socialização, a coordenação, e a criatividade, assim como ajuda crianças e adolescentes a perderem a timidez, a desenvolver a noção do trabalho em grupo e se interessar mais por textos e autores variados.

Segundo Garcia (2000: 101) "o teatro é um pot-pourri de linguagens [...]. Trabalhamos música, artes plásticas, voz, corpo e teatro propriamente dito". Para Massaro (2008: 68), o teatro é uma linguagem composta pela articulação de "signos visuais, sonoros, linguísticos, paralinguísticos e espaciais".

Esta articulação de signos, cujo trabalho pedagógico costuma ser compartimentado pela escola, é pertinente ao universo infantil. Assim, práticas adjetivamente teatrais, nos termos de Massaro, ou seja, atividades oriundas do domínio teatral, ainda que não sejam Teatro enquanto Arte, podem ser consideradas como formas lúdicas e são só atrair a atenção das crianças, mas, sobretudo, envolvê-las num jogo ficcional. Dentre essas práticas adjetivamente teatrais, destacamos, o jogo dramático infantil que veremos de forma mais aprofundada a seguir. ${ }^{47}$

\footnotetext{
${ }^{47}$ Além do jogo dramático infantil, merecem destaque as técnicas atreladas ao teatro de máscaras, de sombras e de fantoches que sendo particularmente pertinentes ao universo infantil, servirão de base a atividades que propusemos ao longo das oficinas experimentais que serão descritas a partir da página 72 desta dissertação.
} 


\title{
1.2.2. Jogo dramático infantil, corporalização e mediação
}

Tendo desenvolvido a questão das Inteligências Plurais ao longo da primeira parte deste capítulo, parece-nos importante ponderar aqui a ideia de que o corpo está ativamente presente no processo de aprendizagem, retomando assim, a inteligência corporalcinestésica.

A língua e o corpo, assim como o corpo e a mente, vêm sendo tratados como dois paradigmas distantes e não relacionáveis. O dualismo filosófico de Platão sugere que a alma (que estamos nos permitindo interpretar como mente) é superior ao corpo e por se tratar de uma prisioneira, vive em completa ignorância, como pode ser visto na afirmação a seguir:

\begin{abstract}
- Vou dizer-te. É uma coisa bem conhecida dos amigos do saber, que sua alma, quando foi tomada sob os cuidados da filosofia, se encontrava completamente acorrentada a um corpo e como que colada a ele; que o corpo constituía para a alma uma espécie de prisão, através da qual ela devia forçosamente encarar as realidades, ao invés de fazê-lo por seus próprios meios e através de si mesma; que, enfim, ela estava submersa numa ignorância absoluta. (PLATÃO, 1972: 94) ${ }^{48}$
\end{abstract}

Essa visão de que o corpo é algo secundário e aprisionador dominou o pensamento humano durante centenas de anos. É na Grécia antiga que o culto à beleza/ao corpo teve seu apogeu. Buscando desenvolver o corpo através de atividades artísticas e atléticas para que este fosse perfeitamente proporcional e gracioso em movimento, equilíbrio e tonicidade, os gregos buscaram a harmonia entre mente e corpo, para que a mente fosse treinada para usar o corpo e o corpo respondesse aos estímulos da mente. (GARDNER, 1994:161)

O aumento significativo de pesquisas na área das Ciências Humanas, assim como o interesse por estudos em psicomotricidade, psicolinguística, dentre outros, nos mostra que o corpo já não está mais tão esquecido na sociedade atual. As inter-relações entre o corpo e a mente deixam de ser consideradas impossíveis e mostram que o ser humano, em especial as crianças, precisam se movimentar.

48 PLATAO. Diálogos. Trad. SOUZA, José Cavalcanti de; PALEIKAT, Jorge; COSTA, João Cruz. São Paulo: Abril Cultural, 1972. 
Porém, no plano educacional Vieira (2002: $31-32)^{49}$ explica que apesar da escola ter como função impulsionar o desenvolvimento social, afetivo, motor e intelectual da criança, logo, integral (corpo e mente), muitas escolas consideram normal, paradoxalmente, que elas permaneçam sentadas durante horas em carteiras individuais que impossibilitam o contato físico e as interações.

Ainda são raras as escolas que estimulam a integração entre os alunos através do corpo, considerada por Massaro (2008: 80) como "fator chave para a aquisição de uma língua estrangeira".

Kishimoto (2012: 58$)^{50}$ afirma que "o brincar com sons, com música, com gestos, tão significativos e agradáveis para a criança, é pouco utilizado pelas instituições infantis, certamente por razões relacionadas à formação e cultura docente", esquecendo dos ensinamentos piagetianos que mostram que a aprendizagem passa pelo corpo, pelo menos quando nos referimos à criança.

Corroborando com esta ideia, o Referencial Curricular Nacional para a Educação Infantil afirma que "gestos, movimentos corporais, sons produzidos, expressões faciais, as brincadeiras e toda forma de expressão, representação e comunicação devem ser consideradas como fonte de conhecimento para o professor sobre o que a criança já sabe. " (BRASIL: 1998a: 33) ${ }^{51}$.

Podemos dizer que na visão de Piaget, o desenvolvimento é essencialmente um processo de estabilizações sucessivas que levam a modos de agir e de pensar cada vez mais complexos e ordenados. Desta forma, é possível considerar que o processo de aprendizagem ocorre por meio de bases que envolvem um corpo em toda sua plenitude e potencial e que este corpo precisa de estímulos que envolvam todos os sentidos.

49 VIEIRA, D. R. Práticas corporais e ensino-aprendizagem de línguas estrangeiras. Dissertação de Mestrado, Universidade de São Paulo, 2002.

${ }^{50}$ KISHIMOTO, T. M. O brincar e a linguagem. In: FARIA, A. L. G. de; MELLO, S. A. (Org.). O mundo da escrita no universo da pequena infância. Campinas: Autores Associados, 2012, p. 45 - 61.

51 BRASIL. Ministério da Educação e do Desporto. Secretaria de Educação Fundamental. Referencial Curricular Nacional para a Educação Infantil / Ministério da Educação e do Desporto, Secretaria de Educação Fundamental. - Brasília: MEC/SEF, 1998. 
Nosso corpo é, genuinamente, um corpo de expressões e movimentos e é através do desenvolvimento sensório-motor para Piaget, ou nas palavras de Gardner, da inteligência corporal-cinestésica, que a criança descobre essas possibilidades.

Como a criança se expressa com o corpo e no corpo, Piaget (1967) afirma que o movimento é considerado como primordial para o desenvolvimento cognitivo e psicomotor infantil. Sendo assim, a interação da criança com ações motoras, visuais e auditivas no mundo que a cerca é essencial para seu desenvolvimento integral, tanto no âmbito escolar quanto em casa, através de estímulos e encorajamento dos pais. ${ }^{52}$

Se mantivermos essas condições ideais para o desenvolvimento infantil enquanto um todo, consequentemente, a apropriação da LE será otimizada, como legitima Weyl ao afirmar que "falar ou ensinar uma língua estrangeira são atividades físicas tanto quanto afetivas e intelectuais, pois ambos requerem investimento corporal completo que solicita todos os órgãos dos sentidos." (WEYL, 1991, apud VIEIRA, 2002: 32).

Embora aprender uma língua estrangeira signifique adquirir novos hábitos corporais e culturais, novos movimentos; segundo Cormansky, (1992: 6) ${ }^{53}$ "o aprendiz de língua estrangeira frequentemente parece um deficiente ao qual conciliamos apenas um modo de expressão, o modo verbal em detrimento de qualquer outro, especialmente, o não-verbal." ${ }^{54}$.

O não-verbal, ou extra-verbal, como prefere o autor, é de extrema importância no contato com a língua estrangeira, porém não estamos mais à vontade com nosso corpo como se deveria. Brook (1991: 76, apud MASSARO, 2008: 96) sublinha que "o que bloqueia a maioria das pessoas hoje em dia, é a fala. Não se deve, portanto, começar com a fala, com as ideias, mas com o corpo. O corpo livre é o primeiro passo".

\footnotetext{
52 Sobre este assunto, vale ressaltar que Slade (1978) além de apresentar para os professores a importância do jogo dramático e sugestões de introdução e aplicação nos diversos níveis escolares, dá alguns conselhos aos pais para estimularem o jogo dramático em casa, mostrando, assim, a importância deste "jogo" para o desenvolvimento infantil.

${ }^{53}$ CORMANSKI, Alex. Le corps dans la langue: Les techniques dramatiques dans l'enseignement/apprentissage des langues étrangères. Thèse pour le Doctorat, Université de La Sorbonne Nouvelle / Paris III, 1992-1993.

54 «L'apprenant en langue étrangère a souvent l'air d'un handicapé à qui on ne semble accorder qu'un seule mode d'expression, le mode verbal au détriment de tout autre, le non verbal notamment. »
} 
Se o corpo deve ser e estar livre, não se pode impedir as crianças de fazerem o que elas fazem de mais natural: brincar e se movimentar.

Para Slade (1978:17), o jogo dramático é um comportamento natural dos seres humanos e é vital para a vida jovem; logo, contribui e faz parte do desenvolvimento infantil. Sendo o jogo dramático essa prática espontânea e estimulante da criatividade, e considerando que ele já integra o currículo de Educação Infantil em algumas instituições, por que não incluí-las nos programas de ensino de LE para as crianças?

O jogo dramático "não é uma atividade de ócio, mas antes a maneira da criança pensar, comprovar, relaxar, trabalhar, lembrar, ousar, experimentar, criar e absorver. O jogo é na verdade a vida." (Idem, 17-18).

Essa afirmação nos faz ponderar que o jogo dramático cria, então, a possibilidade da criança ser ao mesmo tempo ela, qualquer um e/ou múltiplas, criando identidades fictícias quando convém ao jogo. Isto porque, espontaneamente, a criança se deixa imergir em novas experiências de sentir e atuar no mundo, mesmo que este mundo seja imaginário. Mas, de todo modo, possibilita à criança de experimentar e compreender as diferenças que formam os seres.

Ora, não é também disso de que se trata a apropriação de uma LE? Conhecer e adentrar uma nova cultura e enunciação em LE? Para Reis (2008) "essa nova enunciação implica em um novo corpo, uma nova identidade que permite ao sujeito [adulto] poder 'ser' inclusive em língua estrangeira" (REIS, 2008:135). ${ }^{55}$

$\mathrm{Na}$ infância, estimular o jogo dramático na aula de LE, permite à criança criar e desenvolver novas ações em contexto ficcional.

Slade chama particularmente nossa atenção ao afirmar que o jogo dramático é uma maneira da criança descobrir "a vida e a si mesma através de tentativas emocionais e físicas e depois através da prática repetitiva." (SLADE, 1978:18). A valia do jogo dramático na aula

\footnotetext{
${ }^{55}$ Ainda que Reis se refira à concepção de jogo dramático defendida por Jean-Pierre Ryngaert na obra "Le jeu
} dramatique en milieu scolaire" na qual ele não se refere ao universo infantil. 
de LE está, então, na possibilidade da criança compreender o mundo exterior a partir da experimentação "imaginária" de relações humanas que acontecem em seu cotidiano, usando a LE em diversas situações e contextos.

Com base nas concepções apresentadas, podemos afirmar, então, que o jogo dramático infantil é uma maneira de inserir a língua estrangeira no cotidiano das crianças, visto que a imaginação e o corpo fazem parte do processo de aprendizagem durante todo o desenvolvimento infantil. A linguagem oral dos bebês e sua significação é apoiados pela linguagem corporal: gestos e sinais. Da mesma forma, a linguagem corporal das crianças mais velhas está vinculada não só a forma que utilizam para se comunicar, mas também para aprender.

Se a atividade motora influencia, como vimos, o desenvolvimento infantil e o processo de aprendizagem passa obrigatoriamente por tudo aquilo que sabemos e vivenciamos, acreditar na educação de um indivíduo sem considerar o seu comportamento motor é uma crença ilusória, pois "o corpo é mais do que simplesmente uma outra máquina [...] Ele é também o recipiente do senso do eu do indivíduo, seus sentimentos e aspirações mais pessoais" (GARDNER, 1994:183) 
2 METODOLOGIA 


\section{Introdução}

Nossa pesquisa é classificada como pesquisa aplicada, de abordagem qualitativa. Concordamos com a concepção proposta por Moreira \& Caleffe (2008), de que o nosso objeto de pesquisa está relacionado a construções de significados constituídas no âmbito social e que, a partir disso, estas construções se tornam passíveis de interpretações, na medida em que são resultantes das experiências vivenciadas entre pesquisador e os outros participantes.

Em relação aos procedimentos técnicos, esta pesquisa é participante, considerando que a pesquisadora interagiu com os membros da situação investigada. Apresenta também caráter exploratório, pois visou proporcionar maior familiaridade com o problema tratado através do estudo de caso precedido de uma pesquisa bibliográfica.

\subsection{Delimitando o caso}

Nova Friburgo é a principal cidade de um polo de colonização suíça formado por uma série de municípios do estado do Rio de Janeiro. Muitas famílias desta cidade são de origem suíça, dentre as quais a minha. Como parte de meu engajamento com a população friburguense e de modo especial com suas comunidades carentes, cuja situação foi agravada pela tragédia natural ocorrida em 2010, almejei contribuir a partir desta pesquisa, na educação das crianças locais, pois desconheço pesquisas que tenham sido realizadas focalizando o ensino/aprendizagem da língua francesa na região de Nova Friburgo.

Assim, oferecer as oficinas experimentais previstas para minha coleta de dados às crianças carentes de Nova Friburgo foi uma maneira de propiciar a descoberta da língua francesa e sua expressão através da cultura suíça como constituinte de suas identidades.

Colonizada em 1818 por mais de duzentas famílias vindas da Suíça, a região que antes se chamava Morro Queimado é rebatizada em homenagem à Fribourg e em 1820 é elevada à categoria de vila, passando a se chamar Nova Friburgo. Em 1824, cerca de 
oitenta famílias de colonos alemães foram desviadas e chegaram à cidade, pois as colônias que os receberiam no Nordeste do país não estavam preparadas para recebê-los. Forma-se assim, a primeira colônia suíço-alemã do Brasil que somente em 1890 é elevada à categoria de cidade.

A grande presença de colonos suíços na cidade marcou o seu desenvolvimento e deixou sua influência através da sua cultura, língua e gastronomia. Vários bairros foram nomeados em língua francesa desde sua elevação à categoria de cidade.

Em 1973 começa um interesse em trazer de volta toda a história da imigração e reunir os descendentes suíços dos dois países nascendo as Associações irmãs FribourgNova Friburgo. Em 1977 há o primeiro grande encontro no Brasil.

Em 1978, após esse primeiro encontro entre os descendentes dos colonos suíços da Suíça e do Brasil, o então vereador Benício Valladares dirigiu-se ao Consulado da França para que este enviasse um professor da Aliança Francesa do Rio de Janeiro para desenvolver o ensino da língua francesa em Nova Friburgo, visto a grande importância e influência desta língua para a cidade. A Aliança Francesa do Rio de Janeiro decidiu, então, criar uma "antena" sob a responsabilidade da professora francesa Annette Bordage Bessa. E somente em 1994, a Aliança Francesa de Paris aprovou a criação e o estatuto da Aliança Francesa de Nova Friburgo que até hoje exerce um importante papel no que diz respeito não só ao ensino da língua francesa, mas também às ações por ela promovidas, objetivando a melhoria da inserção social da comunidade friburguense.

Em 1987 as associações decidem fazer algo que marque os laços entre as duas cidades e constroem a Queijaria Escola de Nova Friburgo para difundir a arte suíça de se fazer queijos na cidade e região.

Como marco da ligação entre os dois países, em 1996 é fundada a Casa Suíça com a função de informar a todo cidadão friburguense e visitantes do município como foi o seu início e toda a trama por traz do processo imigratório dos mais de 2000 suíços que vieram colonizar Nova Friburgo. A Casa Suíça é formada então pela já existente Queijaria Escola, 
uma Chocolataria doada pela Nestlé, um restaurante temático e o Museu da Colonização que resgata e história da cidade e reconstrói a vida dos primeiros colonos suíços.

No ano de 2007, em parceria com a Aliança Francesa de Nova Friburgo, a prefeitura municipal distribuiu pelo centro da cidade placas bilíngues (português e francês) com os nomes das ruas e uma breve explicação sobre sua origem, como uma forma de homenagear a língua dos colonos e manter os estreitos laços entre as cidades.

\subsection{Fases da pesquisa}

Para o desenvolvimento da pesquisa, realizamos a aplicação de duas oficinas experimentais de língua francesa, cujos resultados formam nosso corpus. Registrada fase por fase em nosso diário de itinerância, a coleta dos dados perdurou de março a dezembro de 2013 e ela é composta pelo contato com as instituições, concepção e realização de duas oficinas experimentais de língua francesa, filmagens das oficinas, entrevistas com os pais ou responsáveis dos participantes, pré-análise da primeira oficina para sua reformulação em segundo oferecimento.

A figura abaixo apresenta o cronograma da coleta de dados:

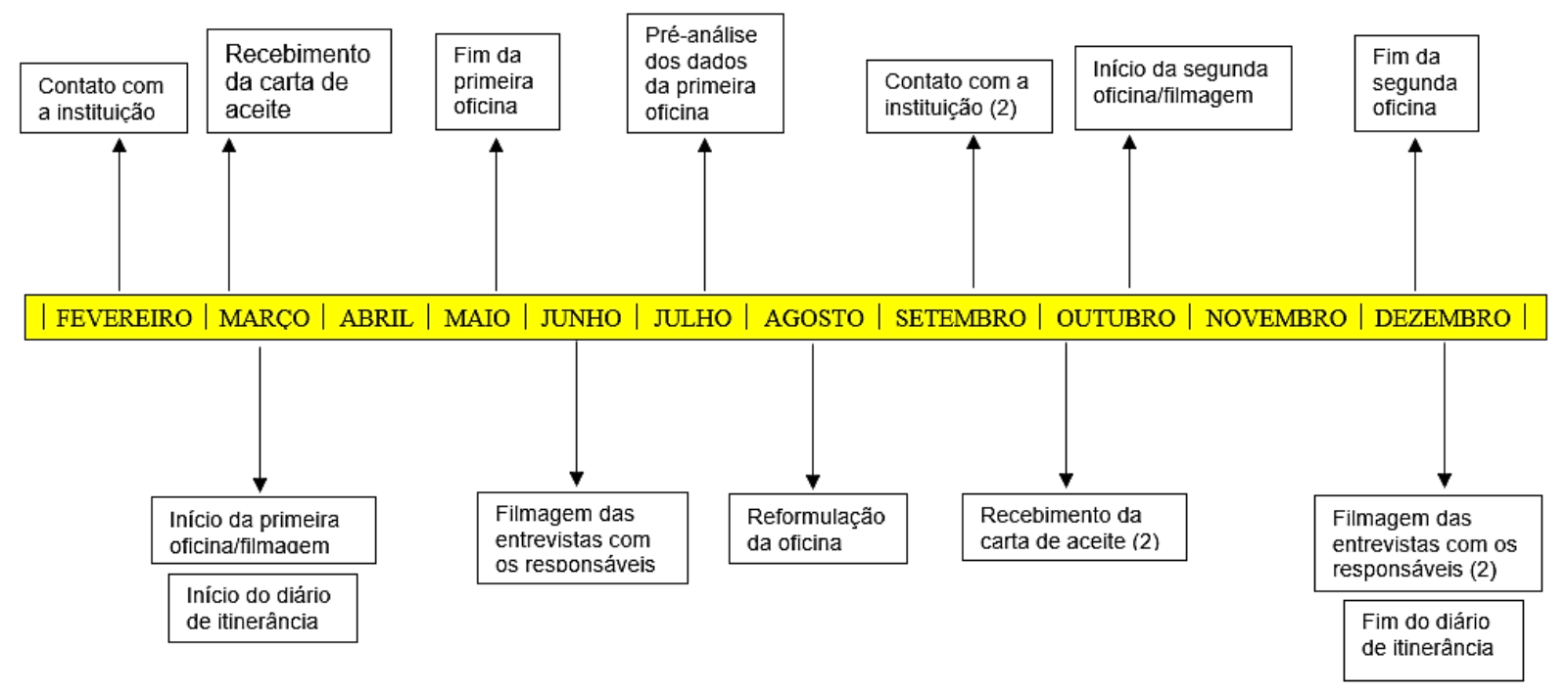

Figura 1 - Cronograma de realização da coleta de dados 
No mês de fevereiro, entramos em contato com o Instituto de Esportes e Cultura de Nova Friburgo, instituição escolhida para o oferecimento da primeira oficina e no início do mês de maio recebemos a carta de aceite. A partir deste momento tivemos alguns encontros com a diretora da instituição para regularizar o local e o início da oficina. No dia 19 de março de 2013, oferecemos a primeira sessão da oficina que resulta no início tanto das filmagens como da escritura do diário de itinerância. A oficina perdura no mês de abril e finda no final do mês de maio, no dia 28 de maio de 2013. Durante esses três meses, após cada sessão, o diário de itinerância ia sendo progressivamente escrito.

O mês de junho foi dedicado à filmagem da entrevista individual com os pais ou responsáveis dos participantes, bem como suas transcrições.

No mês seguinte, realizamos a pré-análise dos dados obtidos a partir da primeira oficina, o que resultou na reformulação de algumas sessões e atividades. Esta reformulação foi executada no mês de agosto.

Em setembro entramos em contato com a Escola Municipal Cecília Meireles, instituição escolhida para o reoferecimento da oficina. No início do mês de outubro, após reuniões e encontros com a direção e professores do colégio, recebemos a carta de aceite. Assim, ao final deste mês, no dia 22 de outubro de 2013 começamos a segunda oficina e sua respectiva filmagem.

No dia 10 de dezembro de 2013 terminamos a segunda oficina e realizamos a filmagem da entrevista coletiva com os pais ou responsáveis dos participantes. Vale ressaltar que esta entrevista foi coletiva pois, segundo a instituição, seria extremamente difícil contatá-los e executar a tarefa individualmente em data especialmente destinada a este fim. Assim, com a autorização da instituição, realizamos a entrevista ao final da reunião escolar de pais de final de ano.

Com o final das oficinas e das entrevistas, terminamos também nosso diário de itinerância. 
Como já explicamos nesta seção, extraímos os dados para as análises de nossa pesquisa das filmagens das oficinas e do diário de itinerância. As entrevistas com os pais ou responsáveis não compõem os dados de nossa pesquisa, pois o enfoque dado por nós na interveniência do agente mediador no ensino de francês não é contemplado nas entrevistas.

A partir da visualização das filmagens, da leitura do diário de itinerância e da observação da produção plástica dos participantes, dividimos a análise das sessões em duas partes; a primeira analisa as sessões em que o agente mediador aparece e a segunda, as em que, em sua ausência, os participantes fazem referência a ele.

A partir desta segmentação, descrevemos cada reação, o comportamento dos participantes, sua interação com o agente mediador e por fim, a receptividade das atividades propostas com e sem a presença do agente mediador.

\subsection{Constituição do corpus}

\subsubsection{A oficina experimental}

Para o desenvolvimento da pesquisa e a aplicação das oficinas experimentais, procuramos uma organização em que as crianças fossem estimuladas a desenvolver habilidades relacionadas à linguagem corporal, a fim de reforçar o eixo central da pesquisa que articula o ensino da língua francesa às múltiplas linguagens. Sendo assim, selecionamos o Instituto de Esportes e Cultura de Nova Friburgo (INEC), na cidade de Nova Friburgo, Rio de Janeiro.

O INEC foi fundado em 2006 com a missão de atender crianças, adolescentes e jovens carentes da cidade, dando aos mesmos uma nova oportunidade de vida. Seu principal objetivo é a inclusão social e a descoberta de novos talentos através do esporte, para tal, atividades como capoeira, dança, ginástica artística, acrobática, rítmica, além de oficinas de manifestações folclóricas são oferecidas. 
A principal atividade do INEC é a ginástica olímpica e para preparar os jovens para tal modalidade esportiva, oficinas e aulas são oferecidas de segunda a sexta-feira por um grupo de professores de Educação Física que se especificaram nas atividades acima relacionadas.

Com o passar dos anos, a equipe principal de ginástica do INEC se classificou com a melhor média do Brasil para o festival internacional Gymnaestrada realizado a cada quatro anos em Lausanne, Suíça. Evento oficial da Federação Internacional de Ginástica, cujos objetivos são os de realizar apresentações, trocar informações sobre os trabalhos desenvolvidos em seus países e discutir a modalidade não competitiva como importante elemento para a cidadania. Sendo assim, a ida dos jovens atletas à Suíça se tornou frequente, ocasionando o interesse da presidência do Instituto ao oferecimento da Língua Francesa para esses jovens.

O objetivo desta experiência foi despertar as crianças desta instituição à língua francesa e à cultura francófona - em sua variante suíça - articulando atividades linguageiras às múltiplas linguagens e à atividades ludo-artísticas.

\subsubsection{Local de realização, carga horária}

Por possuir uma sede pequena que não suportaria todos os materiais necessários para o treino das equipes, o INEC dispõe de um local específico para as aulas práticas que se localiza em um conhecido clube da cidade chamado Nova Friburgo Country Clube, local utilizado também por nós para o oferecimento da oficina.

A sala disponibilizada para a oficina era grande e, a pedido da própria pesquisadora, possuía apenas uma mesa grande e algumas cadeiras. Optamos por esta estruturação para poder criar os ambientes de cada sessão de acordo com o tema de cada sequência didática.

A oficina aconteceu entre os meses de março e maio do ano de 2013 , em duas sessões semanais de 50 minutos cada, perfazendo uma carga horária de 14 horas. 


\subsubsection{O público alvo}

O público que frequenta este instituto tem um perfil variado e para o oferecimento da nossa oficina, foram selecionadas as crianças com idade entre 6 e 7 anos, por se tratar de crianças em processo de alfabetização.

O grupo final participante da oficina contava com quatro meninas de 6 anos e a uma de 7 anos. Dentre essas meninas, uma deixou de integrar a equipe de ginástica durante o andamento da oficina, mas continuou a frequentar as sessões.

Em entrevista com os pais destas crianças, constatamos que nenhuma das famílias falava francês e, de maneira geral, o interesse na oficina foi a possibilidade do contato com uma língua estrangeira.

\subsubsection{Seleção e elaboração das atividades}

As atividades escolhidas para integrarem o programa da oficina foram elaboradas gradualmente através de pesquisas em livros de atividades de língua francesa, métodos de FLE para crianças e sites pedagógicos franceses levando em consideração as necessidades e especificidades do público em questão.

Para melhor explicar a seleção e a elaboração dessas atividades, detalharemos a seguir a metodologia de ensino desenvolvida durante as oficinas.

Como o objetivo da oficina era uma iniciação à língua francesa, organizamos sequências didáticas que abordaram os seguintes temas: cultura francófona (em sua variante suíça), apresentar-se ou apresentar alguém, e vocabulário como números, cores, partes do corpo e animais.

As sequências didáticas foram organizadas pela concepção de atividades ligadas entre si, planejadas para ensinar um conteúdo, não em ordem linear, mas sim em progressão espiralada Nossas sequências didáticas foram organizadas de acordo com os 
objetivos da oficina e cada uma varia em relação à duração e à quantidade de sessões, pois partem do nível de conhecimento que as crianças supostamente tinham sobre cada determinado tema.

Sendo assim, essas sequências didáticas foram compostas por várias sessões, dependendo da recepção e facilidade/dificuldade das crianças com o tema. Para cada sessão foi elaborada uma ficha pedagógica que continha as atividades a serem executadas.

A primeira oficina foi separada em cinco sequências didáticas (SD) compostas das seguintes sessões:

- SD 1 - Se présenter ou présenter quelqu'un

\begin{tabular}{|l|c|c|}
\hline Título da sessão & Data do oferecimento & $\begin{array}{l}\text { Número de crianças } \\
\text { participantes }\end{array}$ \\
\hline Sessão 2: Marie parle français & 21 de março de 2013 & 5 \\
\hline $\begin{array}{l}\text { Sessão 12: Marie se présente à } \\
\text { nouveau }\end{array}$ & 07 de maio de 2013 & 4 \\
\hline $\begin{array}{l}\text { Sessão 13: La famille se } \\
\text { présente + Fête des mères }\end{array}$ & 09 de maio de 2013 & 5 \\
\hline Sessão 16: Les amis de Marie & 27 de maio de 2013 & 5 \\
\hline
\end{tabular}

- SD 2 - Les nombres et les couleurs

\begin{tabular}{|l|c|c|}
\hline Título da sessão & Data do oferecimento & $\begin{array}{c}\text { Número de crianças } \\
\text { participantes }\end{array}$ \\
\hline Sessão 4: Je compte jusqu'à 10 & 02 de abril de 2013 & 5 \\
\hline $\begin{array}{l}\text { Sessão 5: Les nombres et les } \\
\text { couleurs }\end{array}$ & 09 de abril de 2013 & 5 \\
\hline $\begin{array}{l}\text { Sessão 6: Les fruits et ses } \\
\text { couleurs }\end{array}$ & 11 de abril de 2013 & 4 \\
\hline Sessão 9: On joue en français & 25 de abril de 2013 & 5 \\
\hline
\end{tabular}


- SD 3 - Les parties du corps

\begin{tabular}{|l|c|c|}
\hline \multicolumn{1}{|c|}{ Título da sessão } & Data do oferecimento & $\begin{array}{c}\text { Número de crianças } \\
\text { participantes }\end{array}$ \\
\hline Sessão 7: Le corps humain & 16 de abril de 2013 & 4 \\
\hline Sessão 8: Le corps humain II & 18 de abril de 2013 & 3 \\
\hline
\end{tabular}

- SD 4- Les animaux

\begin{tabular}{|l|c|c|}
\hline \multicolumn{1}{|c|}{ Título da sessão } & Data do oferecimento & $\begin{array}{c}\text { Número de crianças } \\
\text { participantes }\end{array}$ \\
\hline $\begin{array}{l}\text { Sessão 10: Les animaux de la } \\
\text { ferme }\end{array}$ & 30 de abril de 2013 \\
\hline $\begin{array}{l}\text { Sessão 11: Les animaux de la } \\
\text { ferme II }\end{array}$ & 02 de maio de 2013 \\
\hline $\begin{array}{l}\text { Sessão 14: La fête des } \\
\text { animaux }\end{array}$ & 14 de maio de 2013 & 5 \\
\hline
\end{tabular}

- SD 5 - La culture

\begin{tabular}{|l|c|c|}
\hline \multicolumn{1}{|c|}{ Título da sessão } & Data do oferecimento & $\begin{array}{c}\text { Número de crianças } \\
\text { participantes }\end{array}$ \\
\hline $\begin{array}{l}\text { Sessão 1: Les langues dans le } \\
\text { monde }\end{array}$ & 19 de março de 2013 & 5 \\
\hline Sessão 3: OEufs de Pâques & 26 de março de 2013 & 4 \\
\hline $\begin{array}{l}\text { Sessão 13: La famille se } \\
\text { présente + Fête des mères }\end{array}$ & 09 de maio de 2013 & 1 \\
\hline Sessão 15: Pâte à sel & 21 de maio de 2013 & 6 \\
\hline
\end{tabular}

Vale ressaltar que a organização das sessões acima apresentadas não está em ordem cronológica, pois optamos por seguir um caminho não-linear durante a oficina, para que pudéssemos "passear" nos temas escolhidos ao longo da evolução das sessões. 
Voltadas não somente ao ensino da língua francesa e da cultura francófona em sua variante suíça, mas também ao desenvolvimento infantil através do lúdico e das múltiplas linguagens, as sessões contemplaram atividades com objetivos e modos de apresentação variados, tentando abranger ao máximo atividades multimodais.

\subsubsection{Reformulação da oficina experimental}

Para o segundo oferecimento da oficina experimental, a fim de manter o eixo central da pesquisa que articula o ensino da língua francesa às múltiplas linguagens, procuramos uma segunda instituição que nos permitisse desenvolver nossa oficina de língua francesa. Durante a procura, nos informamos sobre a Escola Municipal Cecília Meireles e, então, através de uma professora da instituição e de uma psicóloga que faz acompanhamentos periódicos no local, ambas estudantes de francês, nossa pesquisa chegou ao conhecimento do corpo diretor da escola, que demonstrou muito interesse em incorporar a oficina no período vespertino.

Sendo assim, a segunda aplicação da oficina aconteceu na Escola Municipal Cecília Meireles (EMCM). Esta escola é fundamentada pela pedagogia Waldorf e tem como base filosófica a Antroposofia. A EMCM funciona em período integral e atende crianças de 2 a 11 anos, funcionando no bairro Cascatinha na cidade de Nova Friburgo, RJ.

Atualmente, ela conta com 7 tipos de classes, assim distribuídas: 2 Maternais, 3 Jardins de Infância (em sistema de creche, com funcionamento de 6 h40 às 18h) e as classes do $1^{\circ}$ ao $5^{\circ}$ ano do Ensino Fundamental (das $7 \mathrm{~h} 35$ às $16 \mathrm{~h}$ ).

Por se tratar de uma escola pública, ela recebe crianças da comunidade local e de outras regiões mais distantes, inclusive de outros distritos e municípios. Parte dos 194 alunos pertence a famílias de trabalhadores da área têxtil, bem como filhos de domésticas e operários da construção civil. Também recebemos famílias de maior poder aquisitivo, que 
optam por esta Escola em função da sua linha pedagógica e qualidade de ensino, configurando assim um interessante cenário de diversidade cultural e social.

Baseados na tríade: ação, sentimento e pensamento; a rotina de sala de aula engloba o desenvolvimento pleno da individualidade, levando-se em conta as diferenças e respeitando cada fase evolutiva da criança. Segundo declaração da própria escola ${ }^{56}$ :

\begin{abstract}
Após o professor saudar cada criança com um caloroso "bom-dia" à porta da classe, exercícios rítmicos são iniciados: bola, corda, palmas e pés, canções e poesias, embalados pelos sorrisos e brincadeiras. Um belo verso encerra as atividades, acalma os movimentos e prepara a todos para um novo dia de trabalho. O dia anterior é lembrado: o que aprendemos? Inicia-se um novo conteúdo, com histórias e desafios. Os próprios cadernos são os livros dos alunos que eles mesmos preparam com belos desenhos e letra caprichada. Emoções e vivências acompanham os conteúdos.
\end{abstract}

Os professores Waldorf se dedicam em transformar o ensino em uma arte que eduque a criança como um todo - o fazer, o sentir e o pensar, o que corrobora com o eixo central de nossa pesquisa. Essa educação almeja desenvolver crianças capazes de, por elas próprias, dar sentido e direção às suas vidas, colocando-os face a atividades da vida cotidiana como música, teatro, jardinagem, técnicas agrícolas e horticultura em meio às exigências curriculares legais.

A pedagogia Waldorf tem como ponto de partida o conhecimento da criança e de seu desenvolvimento em diversos aspectos e reconhece o ser humano como ente físico, anímico e espiritual. Preocupando-se com o desenvolvimento global dos alunos, suas diferenças individuais e o destaque em descobrir suas capacidades e potencial, possui um currículo vivo, dinâmico e integrado, desenvolvido em bases antropológico/antroposóficas, que abrangem a evolução física, emocional e espiritual do ser humano.

O objetivo desta experiência foi despertar um grupo de crianças desta escola à língua francesa e à cultura francófona - em sua variante suíça - articulando as atividades reformuladas a partir do oferecimento da primeira oficina, sempre atrelando atividades linguísticas às múltiplas linguagens e a atividades lúdicas.

${ }^{56}$ Disponível em http://www.valedeluz.org.br/ensinofundamentalcmeireles.php 


\subsubsection{Local de realização, carga horária}

A escola se localiza em um bairro residencial da cidade de Nova Friburgo e possui um grande espaço físico. As sessões aconteciam na maior parte do tempo na sala de aula já ocupada pelas crianças em seu cotidiano com a professora responsável; quando possível, devido às condições climáticas e mediante autorização da escola, usávamos o espaço externo e o refeitório.

A sala de aula continha mesas e cadeiras para todas as crianças, um quadro negro e um banheiro. O fato de já haver na sala muitas mesas e cadeiras dificultou, em partes, a criação do ambiente adequado em algumas sessões, embora tivéssemos autorização para deslocar os móveis quando necessário. No refeitório, que possuía mesas agrupadas que facilitavam o trabalho em grupo, tínhamos acesso a todos os utensílios de cozinha.

A segunda oficina aconteceu entre os meses de outubro e dezembro do ano de 2013, em duas sessões semanais de 50 minutos cada, perfazendo uma carga horária de 12 horas.

\subsubsection{O público alvo}

O grupo de participantes selecionado pela escola para participar da oficina foi a turma de $1^{\circ}$ ano do Ensino Fundamental que frequentava a escola no período da tarde.

Para esclarecimento, a escola que funciona em período integral, realiza aulas e atividades regulares na parte da manhã e, para as famílias que desejam, na parte da tarde possui uma complementação com atividades lúdicas, oficinas, etc.

Como a frequência na parte da tarde não é obrigatória, o grupo variava de 13 a 15 crianças, com idade de 6 a 8 anos, em processo de alfabetização. Das 15 crianças, 6 eram meninos e 9 eram meninas. 
Em entrevista com os pais destas crianças, constatamos que, mais uma vez, nenhuma das famílias falava francês, com exceção dos avós de uma menina.

\subsubsection{Seleção e elaboração das atividades}

As atividades escolhidas para integrarem o programa desta segunda oficina foram reelaboradas a partir da primeira oficina levando em consideração as necessidades e especificidades do público em questão, bem como as exigências da escola, que por se tratar de uma escola Waldorf, limita o uso de alguns materiais e suportes.

Assim como para a primeira oficina, para melhor explicar a nova seleção e a elaboração das atividades, detalharemos a seguir a metodologia de ensino desenvolvida durante esta segunda oficina.

Visto que o objetivo da oficina se mantinha (iniciação à língua francesa), mantivemos os temas das sequências didáticas da primeira oficina: cultura francófona (em sua variante suíça), apresentar-se ou apresentar alguém, e vocabulário como números, cores, partes do corpo e animais. As mudanças realizadas se referem apenas à quantidade e ao conteúdo de cada sessão.

A segunda oficina foi separada em cinco sequências didáticas (SD) compostas das seguintes sessões

- SD 1 - Se présenter ou présenter quelqu'un

\begin{tabular}{|l|c|c|}
\hline \multicolumn{1}{|c|}{ Título da sessão } & Data do oferecimento & $\begin{array}{c}\text { Número de crianças } \\
\text { participantes }\end{array}$ \\
\hline Sessão 1: Marie parle français & 22 de outubro de 2013 & 12 \\
\hline $\begin{array}{l}\text { Sessão 10: Marie se présente à } \\
\text { nouveau }\end{array}$ & 26 de novembro de 2013 & 10 \\
\hline Sessão 11: Les amis de Marie & 29 de novembro de 2013 \\
\hline $\begin{array}{l}\text { Sessão 13: Les amis de Marie } \\
\text { se présentent }\end{array}$ & 06 de dezembro de 2013 & 11 \\
\hline
\end{tabular}


- SD 2 - Les nombres et les couleurs

\begin{tabular}{|l|c|c|}
\hline \multicolumn{1}{|c|}{ Título da sessão } & Data do oferecimento & $\begin{array}{c}\text { Número de crianças } \\
\text { participantes }\end{array}$ \\
\hline Sessão 2: Je compte jusqu'à 10 & 25 de outubro de 2013 & 14 \\
\hline $\begin{array}{l}\text { Sessão 3: Les nombres et les } \\
\text { couleurs }\end{array}$ & 29 de outubro de 2013 \\
\hline $\begin{array}{l}\text { Sessão 4: Les fruits et ses } \\
\text { couleurs }\end{array}$ & 01 de novembro de 2013 & 12 \\
\hline Sessão 7: On joue en français & 12 de novembro de 2013 & 13 \\
\hline
\end{tabular}

- SD 3 - Les parties du corps

\begin{tabular}{|l|c|c|}
\hline \multicolumn{1}{|c|}{ Título da sessão } & Data do oferecimento & $\begin{array}{c}\text { Número de crianças } \\
\text { participantes }\end{array}$ \\
\hline Sessão 5: Le corps humain & 05 de novembro de 2013 & 13 \\
\hline Sessão 6: Le corps humain II & 08 de novembro de 2013 & 12 \\
\hline
\end{tabular}

- SD 4 - Les animaux

\begin{tabular}{|l|c|c|}
\hline \multicolumn{1}{|c|}{ Título da sessão } & Data do oferecimento & $\begin{array}{c}\text { Número de crianças } \\
\text { participantes }\end{array}$ \\
\hline $\begin{array}{l}\text { Sessão 8: Les animaux de la } \\
\text { ferme }\end{array}$ & 19 de novembro de 2013 & 14 \\
\hline $\begin{array}{l}\text { Sessão 9: Les animaux de la } \\
\text { ferme II }\end{array}$ & 22 de novembro de 2013 & 12 \\
\hline
\end{tabular}

- SD 5 - La culture

\begin{tabular}{|l|c|c|}
\hline \multicolumn{1}{|c|}{ Título da sessão } & Data do oferecimento & $\begin{array}{c}\text { Número de crianças } \\
\text { participantes }\end{array}$ \\
\hline $\begin{array}{l}\text { Sessão 12: Les boules du } \\
\text { sapin de Noël }\end{array}$ & 03 de dezembro de 2013 & 13 \\
\hline Sessão 14: Pâte à sel & 10 de dezembro de 2013 & 13 \\
\hline
\end{tabular}




\subsection{Instrumentos de coleta de dados}

Nesta seção explicaremos mais detalhadamente os instrumentos utilizados para a produção de dados desta pesquisa, ou seja, as gravações e o diário de itinerância da professora/pesquisadora.

\subsubsection{As vídeo-gravações}

Quanto aos aspectos técnicos, as filmagens das aulas foram realizadas pela própria pesquisadora com o uso de material de filmagem pessoal (câmera de vídeo e tripé). material foi gravado em formato .mp4.

A câmera foi posicionada ao fundo da sala, focalizando os participantes. Como as salas eram pequenas e a professora se movimentava bastante, por vezes ela não aparece em trechos da filmagem, podendo ouvir apenas sua voz. Nos momentos de produção como desenho, recorte, pintura, dentre outros, a professora pegava a câmera e filmava os participantes mais de perto como se pode ver nas imagens abaixo:

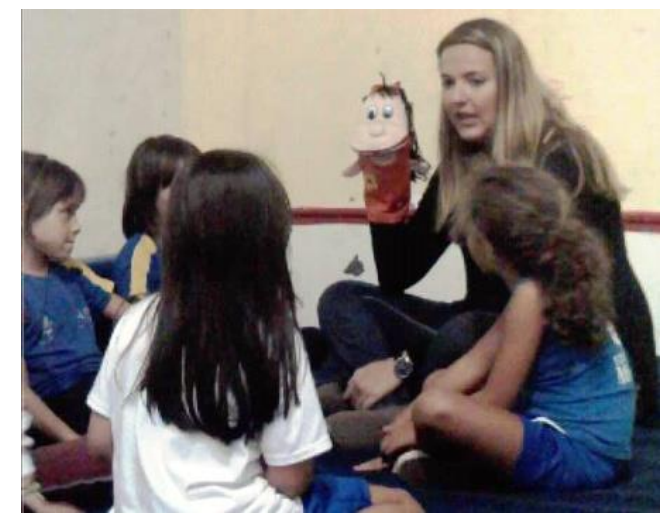

Figura 2 - Filmagem da sessão - $1^{\text {a }}$ oficina

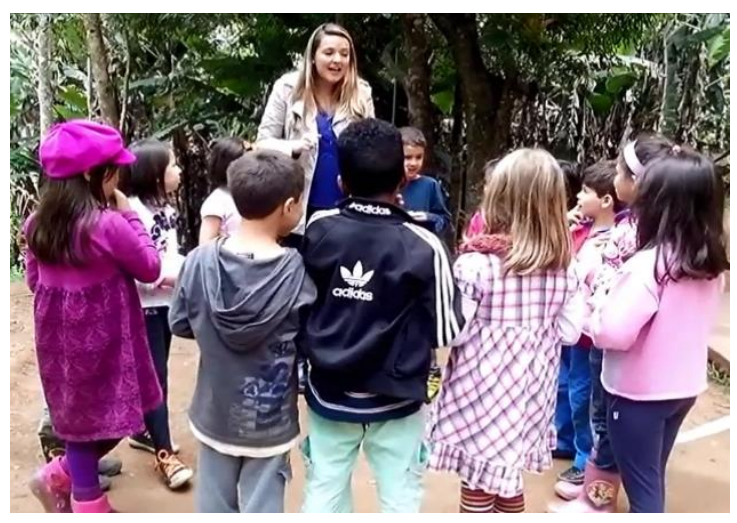

Figura 3 - Filmagem da sessão $-2^{\underline{a}}$ oficina 


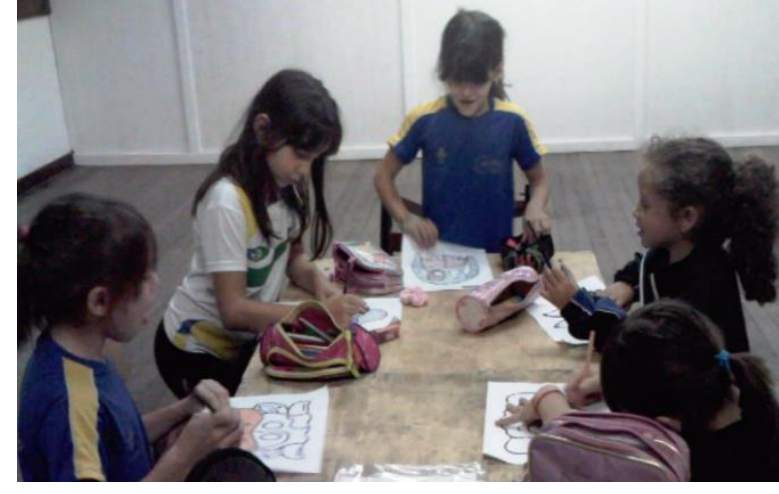

Figura 4 - Participantes colorindo - 1a oficina

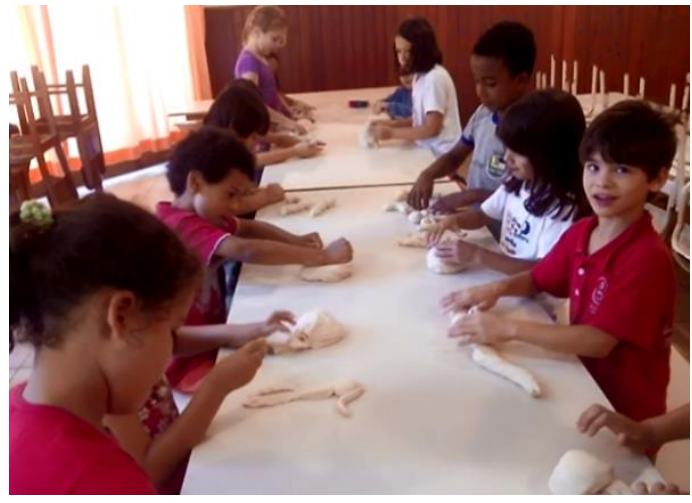

Figura 5 - Participantes modelando $-2^{\underline{a}}$ oficina

\subsubsection{O diário de itinerância da pesquisadora}

Para a realização do diário de itinerância, utilizamos a técnica de pesquisa proposta por Barbier $(2007)^{57}$. Segundo o autor, este tipo de técnica desenvolvida na pesquisa ação mantem o caráter de intimidade dos diários íntimos, porém com a particularidade de poder ser difundido e/ou publicado. Este diário de itinerância seria, então, uma espécie de "bloco de apontamentos no qual cada um mostra o que sente, o que pensa, o que medita, o que poetiza, o que retém de uma teoria, de uma conversa" (idem, 2007: 133).

Por parte da pesquisadora, o diário de itinerância foi redigido progressivamente junto ao acontecimento das sessões das oficinas oferecidas, contendo uma descrição do desenvolvimento das sessões, observações sobre as atividades, o comportamento das crianças, fatos interessantes que aconteceram no pré e pós sessão, impressões da pesquisadora sobre a receptividade das crianças face às atividades e aos conteúdos propostos, dentre outros.

Assim sendo, o diário de itinerância se apresentou como fundamental para este tipo de pesquisa como será visto no capítulo seguinte. Neste capítulo, os resultados mostram a grande utilidade deste tipo de instrumento, visto que, as vídeo-gravações apresentaram

\footnotetext{
${ }^{57}$ BARBIER, René. A pesquisa-ação. Brasília: Liberlivro, 2007.
} 
alguns ruídos, barulho externo e demais interferências que impediram a boa compreensão e transcrição de alguns dados, cuja utilização só foi possível graças ao registro da pesquisadora. 
3 ANÁLISE DE RESULTADOS 
Neste capítulo, apontaremos os resultados obtidos nas análises das vídeo-gravações das sessões de ambas as oficinas. Como já foi explicado anteriormente ${ }^{58}$, no segundo oferecimento da oficina, a ordem e o conteúdo das sessões sofreram algumas alterações em relação ao primeiro oferecimento. Estas mudanças ocorreram ora por questões de adaptação aos preceitos da metodologia adotada pela escola (ou seja, a Metodologia Waldorf), ora em virtude da reformulação de nossas hipóteses após a primeira experiência. Destacamos aqui a importância de um segundo oferecimento da oficina. Reformular a experiência centrada em hipóteses que foram reformuladas graças aos resultados obtidos ao longo da primeira testagem revelou-se fundamental para a conclusão desta pesquisa: sobretudo no que diz respeito à interveniência do agente mediador.

O agente mediador por nós eleito para as oficinas foi um fantoche de pano colorido que se apresentava como uma menina suíça chamada Marie. Considerando este agente mediador como objeto de nossas análises, organizamos nossa exposição analítica em duas etapas: na primeira, descreveremos a reação das crianças no momento das aparições do agente mediador e os seus comportamentos para com ele. Na segunda, abordaremos os momentos em que houve uma evocação espontânea desse agente mediador pelas crianças. Paralelamente, refletiremos sobre a interação das crianças durante as atividades didáticas que articularam múltiplas linguagens e durante atividades corporais em língua estrangeira.

\footnotetext{
${ }^{58}$ Nas páginas 63 a 67.
} 


\subsection{As aparições do fantoche}

O uso do fantoche aconteceu pela primeira vez na primeira oficina (PO) durante a segunda sessão ${ }^{59}$ e, na segunda oficina (SO), seu uso ocorreu logo na primeira sessão ${ }^{60}$. Ambas se intitularam "Marie parle français".

No início de ambas as sessões, a professora recebeu calorosamente as crianças dizendo que, naquele dia, tinha uma surpresa para elas e lhes mostrou uma caixa. De dentro da caixa apareceu um fantoche.

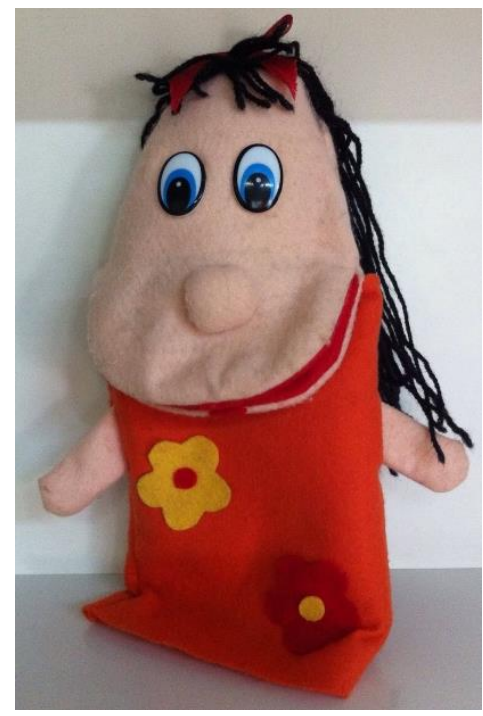

Figura 6 - $\mathrm{O}$ agente mediador

$\mathrm{Na} \mathrm{PO}$, ao sair da caixa, o fantoche se direcionou às crianças e disse: “Je m'appelle Marie". Nesse momento, enquanto a professora-pesquisadora começava a questionar às crianças sobre o que o fantoche teria dito, uma das crianças disse que era a professora quem estava falando, mas não houve reação por parte das demais crianças e, então, a professora-pesquisadora continuou com uma breve explicação sobre quem era o fantoche,

\footnotetext{
${ }^{59} \mathrm{Na}$ primeira sessão desta oficina fizemos uma introdução às línguas estrangeiras. Através de um globo terrestre e de imagens de habitantes de diversos países, fizemos com as crianças uma conscientização da existência de outros países, línguas e culturas.

${ }^{60}$ Ao informar à escola como se desenvolveria a primeira sessão, a Direção argumentou que as crianças haviam acabado de passar por uma situação de conscientização parecida com a que proporíamos, pois recentemente uma professora havia ministrado algumas aulas de língua alemã, além da língua inglesa que já faz parte do currículo escolar. Assim, passamos diretamente à apresentação do fantoche.
} 
explicando que ele teria vindo para ajudar a aprender francês. Ao perguntar se o fantoche poderia ficar na sala, recebeu uma resposta positiva e calorosa. ${ }^{61}$

Em seguida, o fantoche cochichou para a professora-pesquisadora que transmitiu a mensagem de que ele gostaria de se apresentar melhor e enquanto cumprimentava as crianças e, posteriormente, se apresentava dizendo nome, idade e nacionalidade, podíamos notar através das expressões faciais, a surpresa e o encantamento das crianças com a presença do agente mediador.

A partir deste momento, ao longo da PO não houve mais questionamentos sobre quem estaria falando, pois o fantoche foi recebido com atitudes positivas por parte das crianças e começou a integrar seus imaginários, como veremos posteriormente. Vale ressaltar que para O’Neil (1993: 140) atitudes são “o reflexo relativamente estável dos sentimentos ou julgamentos a respeito de alguma coisa. Além disso, eles influenciam as posições tomadas e/ou o comportamento em determinada situação."62

$\mathrm{Na} \mathrm{SO}$, com algumas mudanças, as primeiras interlocuções se realizaram de maneira triangular: extremamente tímida após sair da caixa, o fantoche direcionava suas falas cochichando à professora-pesquisadora que, por sua vez, as transmitia às crianças. Inversamente, quando as crianças tomavam a palavra para conversar com o fantoche, passavam pela mediação da professora-pesquisadora. ${ }^{63}$

Transcrevemos abaixo um trecho da interação inicial das crianças com o fantoche, onde doravante F: fantoche, P: professora, Cs: todas/várias crianças e C(acompanhado de um número): cada participante.

$$
\begin{aligned}
& \text { F: Bonjour! } \\
& \text { Cs: Bonjour! } \\
& \text { F: Je m'appelle Marie. Je viens de la Suisse. }
\end{aligned}
$$

${ }^{61}$ Não foi, infelizmente, possível transcrever esta interação da primeira oficina devido a ruídos na gravação. Nossas análises baseiam-se, portanto, no diário de itinerância da pesquisadora, instrumento fundamental para o desenvolvimento de uma pesquisa desta natureza.

62 « le reflet relativement stable des sentiments ou jugements à l'égard de quelque chose. Par ailleurs, elles influencent les positions prises et/ou le comportement dans une situation donnée. »

${ }^{63}$ Como se pode ver no DVD que acompanha este estudo. 
C1: Quer dizer, eu venho da Suíça!

$\mathrm{P}$ : Muito bem! Mais o que será que ela falou?

C1: É... Bom dia?

$\mathrm{P}$ : Bom dia, boa tarde. Mais o quê? Vamos pedir pra ela repetir? - Marie, tu peux répéter?

F: Bonjour!

Cs: Bonjour!

C1: Bom dia!

F: Je m'appelle Marie, je viens de la Suisse.

C3: Eu venho da Suíça e meu nome é Marie.

P: Muito bem! Isso aí! A Marie tá super contente que todo mundo entendeu ela. Sabe porquê? A Marie não entende quando a gente fala na nossa língua. A Marie só entende francês.

C4: Ela só tá... Ela não tá te entendendo.

P: Ela não tá me entendendo agora. Quando eu falo com vocês ela não entende, porque ela só fala francês. Então pra gente falar com ela, a gente vai ter que falar francês. O quê que vocês acham da gente falar o nosso nome pra ela? A gente vai fazer assim ó, a gente vai fazer igual ela falou. Ela vai me perguntar e depois ela vai perguntar pra cada um de vocês e a gente vai responder pra ela. Tá bom?

F: Bonjour, je m'appelle Marie. Et toi?

$\mathrm{P}$ : Bonjour, je m'appelle Livia.

$[\ldots]$

F: Bonjour, je m'appelle Marie. Et toi ?

C6: Bonjour, ...e m'appelle Kathelin.

$\mathrm{P}$ : Muito bem! Ele tá com vergonha! Marie, il est très timide comme toi!

C1: Ele é como você!

$\mathrm{P}$ : Ahn, ela falou que como ela tem muita muita vergonha também, não tem problema! Que aí, quando ele quiser, ele fala com ela, né?

$\mathrm{F}$ : Bonjour, je m'appelle Marie. Et toi?

P9: Bonjour, je m'appelle Carol.

F: Bonjour, je m'appelle Marie. Et toi?

$[\ldots]$

P: Ela falou que está super feliz de ter conhecido vocês...

C1: E agora vou embora!

$P$ : Ela quer falar com vocês, pode ser?

C10: Não, não pode!

C13: Ela consegue falar em português?

P: Não, não consegue. A gente vai ter que ensinar pra ela depois, mas primeiro ela vai ensinar o francês pra gente, tá? Ela quer falar uma coisa, vou deixar ela falar.

$F:$ Je viens de la Suisse.

C3: Eu venho da Suíça. [...]

Em ambas as oficinas, após esse momento de interação inicial, as crianças responderam em francês às perguntas do fantoche Comment tu t'appelles? e Quel est ton 
âge? - baseadas nas respostas da professora-pesquisadora a quem o fantoche se dirigia primeiramente. Porém, na SO, enquanto o fantoche cumprimentava, se apresentava e interagia com as crianças, notamos que as meninas estavam mais receptivas e dispostas a responder às perguntas de Marie, enquanto os meninos ficaram mais tímidos e tiveram certo acanhamento na hora de se comunicar. Um deles não quis interagir.

Em seguida, o fantoche anunciou ter uma surpresa: uma música; e propôs que as crianças a ouvissem. A música escolhida está transcrita a seguir:

\begin{abstract}
Youpi, c'est parti. Bonjour les amis / Les grands, les petits, venez vous amuser. / Chanter et danser avec Félix et Lila. / On tape les pieds, on lève les bras. / Youpi, c'est parti. Bonjour les amis / Les grands, les petits, venez vous amuser. / Apprendre le français avec Félix et Lila. / On frappe les mains, on claque les doigts. / Et on crie : Houra! ${ }^{64}$
\end{abstract}

Como vimos, Brook (1991: 76, apud MASSARO, 2008: 96) afirma que na aprendizagem de uma LE, o corpo livre é o primeiro passo e a música apresentada permitiu que as crianças entrassem no ritmo e acompanhassem a professora na dança. desbloqueio do corpo envolveu as crianças na atividade que espontaneamente começaram a cantar alguns trechos que continham palavras mais transparentes, corporalizando a língua estrangeira e estimulando as inteligências corporal-cinestésica, linguística e musical. ${ }^{65}$

Para encerrar as sessões tanto da PO como da SO, a professora-pesquisadora propôs uma mesma atividade de produção plástica, cujo objetivo era a representação livre do fantoche através de um desenho. Assim as crianças que estavam sentadas em círculo no chão, foram até suas mesas e começaram a desenhar.

Em um dado momento da produção na PO, uma das meninas começou a cantar espontaneamente um trecho do hino da cidade de Nova Friburgo e foi seguida pelas outras: "Salve, brenhas do Morro Queimado,/ Que os suíços ousaram varar,/ pois que um século

\footnotetext{
${ }^{64}$ Youpi, c'est parti. In : VANTHIER, Hélène; SCHMITT, Sylvie. CD Zig Zag 1: Méthode de Français. Paris: CLE International, 2011.

${ }^{65}$ Vide DVD.
} 
agora é passado,/ Vale a pena esse tempo lembrar"66, o que mostra um entrelaçamento das linguagens plástica e musical, atestando a ativação das inteligências musical, corporalcinestésica, espacial e interpessoal, propostas por Gardner (1994; 1995).

Esta criança que começou a cantar o hino, evoca através dele sua própria identidade e a traz para a aula de língua francesa, reconhecendo, embora inconscientemente, elementos semelhantes entre ela e o fantoche, que, para a crianças, possui sua própria identidade e cultura.

Neste momento, a professora-pesquisadora que estava com a câmara de vídeo nas mãos filmando o processo de criação das crianças, explicou o porquê do hino de Nova Friburgo falar sobre os suíços, o que deixou as crianças motivadas, questionando se o fantoche era originário da cidade e imaginando que a família do fantoche havia morado em Nova Friburgo antigamente.

Segundo O’Neil (1993:140) a motivação pode ser “interna ou externa, vir do próprio aprendiz ou ser estimulada pelo professor" ${ }^{\prime \prime 7}$ e a reação das crianças, motivadas pelas informações recebidas, mostra a mescla entre o real da informação fornecida pela professora e o fictício, que é a imaginação das crianças criando uma história de vida para o fantoche e sua família, personificando o agente mediador e o reconhecendo como parte constituinte do grupo.

Notamos ainda neste trecho o papel de agente mediador exercido, desta vez, pela professora, que além de trazer um novo conhecimento, auxilia as crianças a compreenderem a ligação entre a história e a cultura de sua cidade e este outro país que elas estão começando a conhecer. Cabe notar que são estes momentos de mediação do conhecimento que auxiliam o desenvolvimento infantil exposto por Vigotski, visto que segundo o autor, a Zona de Desenvolvimento Proximal trata-se da distância entre o nível de desenvolvimento real, ou seja, tudo aquilo que a criança já sabe e faz sozinha e o nível de

\footnotetext{
${ }^{66}$ Vide DVD.

67 «[... interne ou externe, venir de l'apprenant lui-même ou être stimulée par l'enseignant.»
} 
desenvolvimento potencial, que se trata de tudo que ela pode saber ou fazer sob o auxílio de um adulto ou uma criança maior.

A seguir, algumas produções em linguagem plástica realizadas nesta sessão:

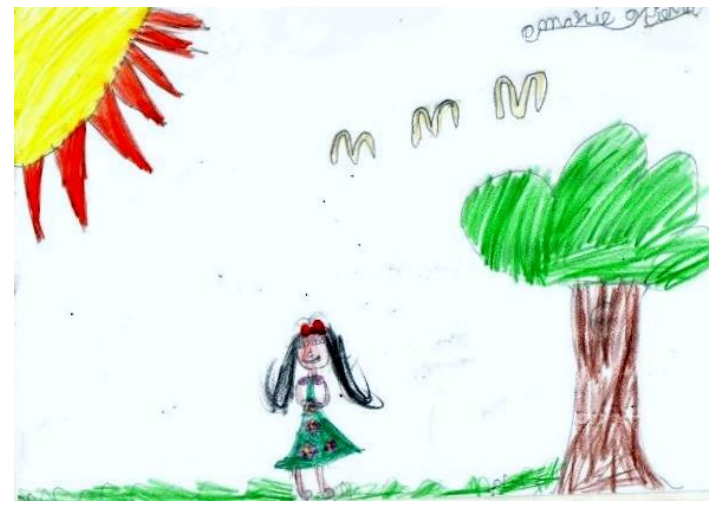

Figura 7 - Desenho da Marie - 1aㅡ oficina

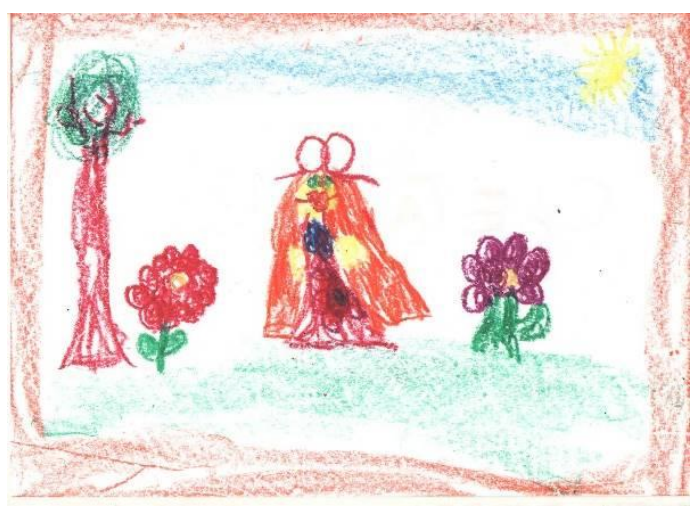

Figura 9 - Desenho da Marie $3-1^{\text {a }}$ oficina

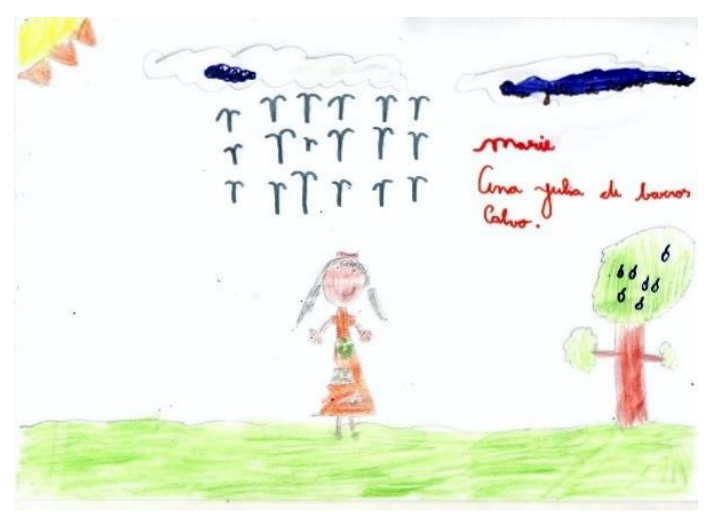

Figura 8 - Desenho da Marie $2-1^{\text {a }}$ oficina

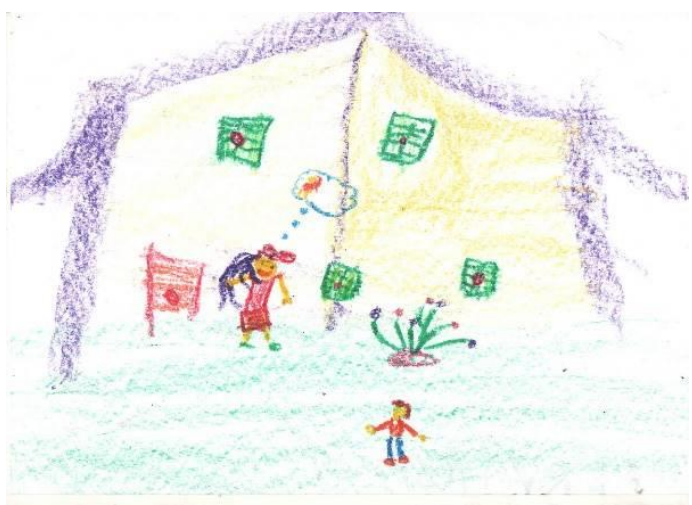

Figura 10 - Desenho da Marie 4 -1를 oficina

No segundo oferecimento da oficina, durante a atividade de produção plástica, as crianças perguntaram se podiam desenhar o fantoche de outro jeito, acrescentando pernas, mudado a cor da roupa e até mesmo junto com seus heróis favoritos, como a Liga da Justiça, etc., demonstrando a incorporação do personagem do fantoche ao seu imaginário lúdico, base para a criação de uma ficção. Após autorização da professora, os desenhos começaram a ser enriquecidos de detalhes e cores. Algumas dessas produções encontramse abaixo: 


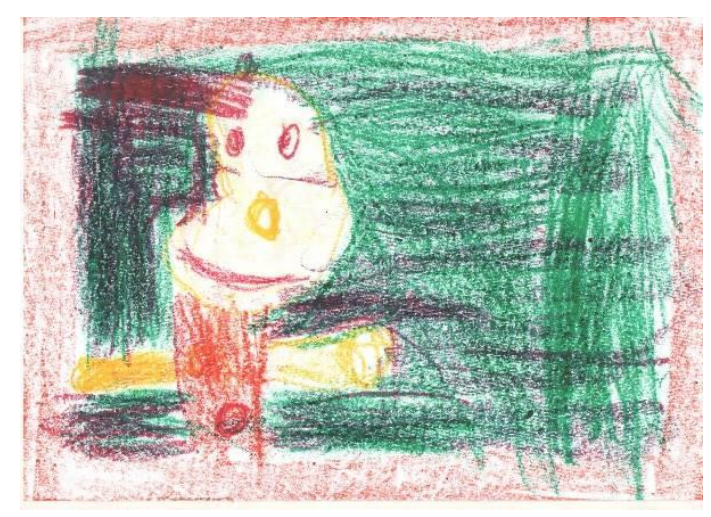

Figura 11 - Desenho da Marie 5 - 2ª oficina

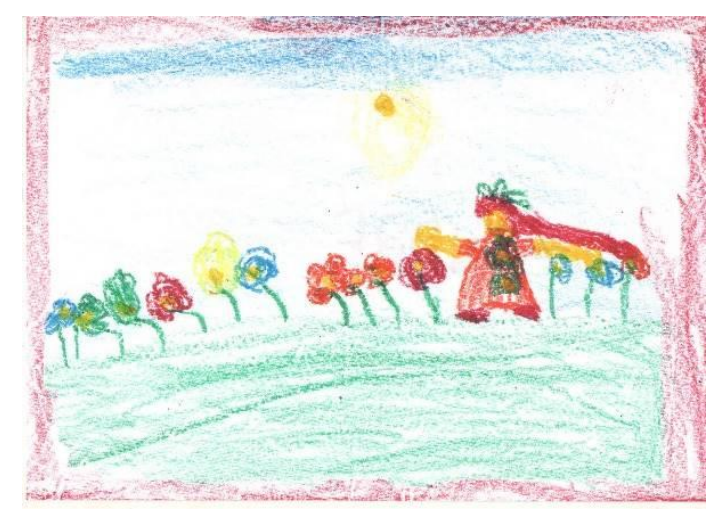

Figura 13 - Desenho da Marie 7 - $2^{\text {a }}$ oficina

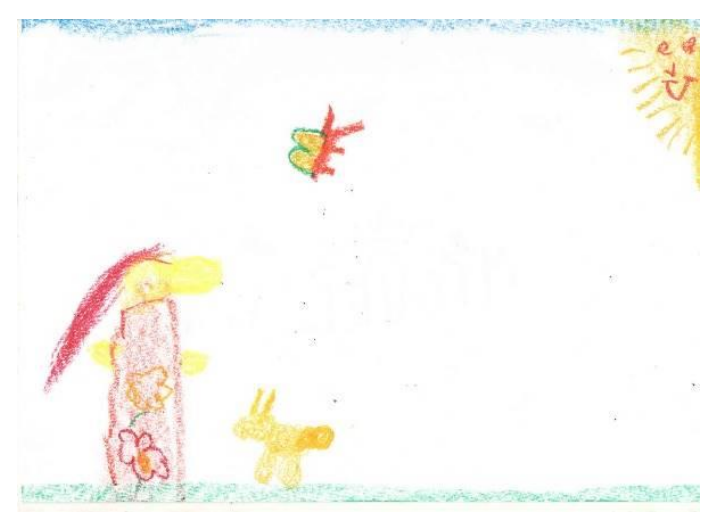

Figura 12 - Desenho da Marie $6-2^{\text {a }}$ oficina

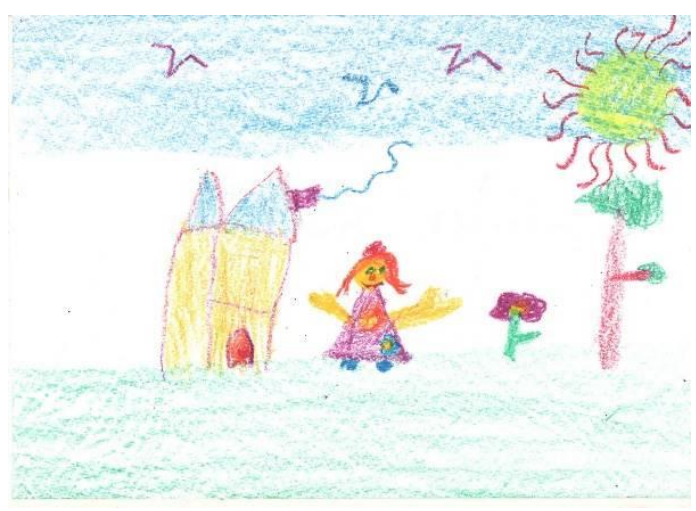

Figura 14 - Desenho da Marie $8-2^{\underline{a}}$ oficina

A próxima aparição do fantoche na PO aconteceu na terceira sessão, intitulada "OEufs de Pâques". Neste dia, em um momento intercultural, a professora-pesquisadora que tinha em mãos o fantoche, disse que ele gostaria que ela contasse um pouco sobre a tradição da Páscoa em seu país. As crianças participaram opinando e se manifestando sobre os costumes no Brasil. Ao falar sobre a tradição da Suíça de presentear as crianças com ovos de galinha coloridos e decorados, as crianças ficaram atentas e curiosas e quando a professora propôs que elas fizessem o mesmo, houve grande receptividade. As crianças estavam motivadas a trabalhar com materiais aparentemente não habituais para elas como as cascas dos ovos, tintas, colas coloridas, pincéis, lantejoulas, etc. 
Uma observação importante sobre esta sessão foi o comentário de uma das crianças no início da aula, que perguntou quando elas começariam a ter aulas de francês ${ }^{68}$. Este depoimento espontâneo nos leva a questionar o que elas entendem por escola e por aprender, ou/e também, que tipo de ensino tem-se apresentado às crianças.

A interação lúdica vivida pelas crianças durante a oficina foi um processo aquisicional que foi não considerado por elas como "aula" ou "trabalho" visto que as atividades nas quais elas se envolveram durante a oficina não correspondem ao tipo de ensino ao qual estão acostumadas: muito provavelmente, atividades realizadas em carteiras diante de uma lousa, configuração que caracteriza abordagens de ensino utilizadas em muitas escolas de ensino regular, bem como em muitos cursos de línguas.

A oficina desenvolvida ofereceu às crianças a experiência de apropriação de uma língua e cultura estrangeira, ou seja, um processo que, sendo fundado na interação lúdica e na inserção dos aprendizes em situações acionais (sejam elas reais ou ficcionais) permitiu a integração inconsciente de elementos linguístico-discursivos e culturais distintos dos que constituem identitariamente a criança em sua língua-cultura materna.

$\mathrm{Na}$ SO, a segunda aparição do fantoche começou com a seguinte interação:

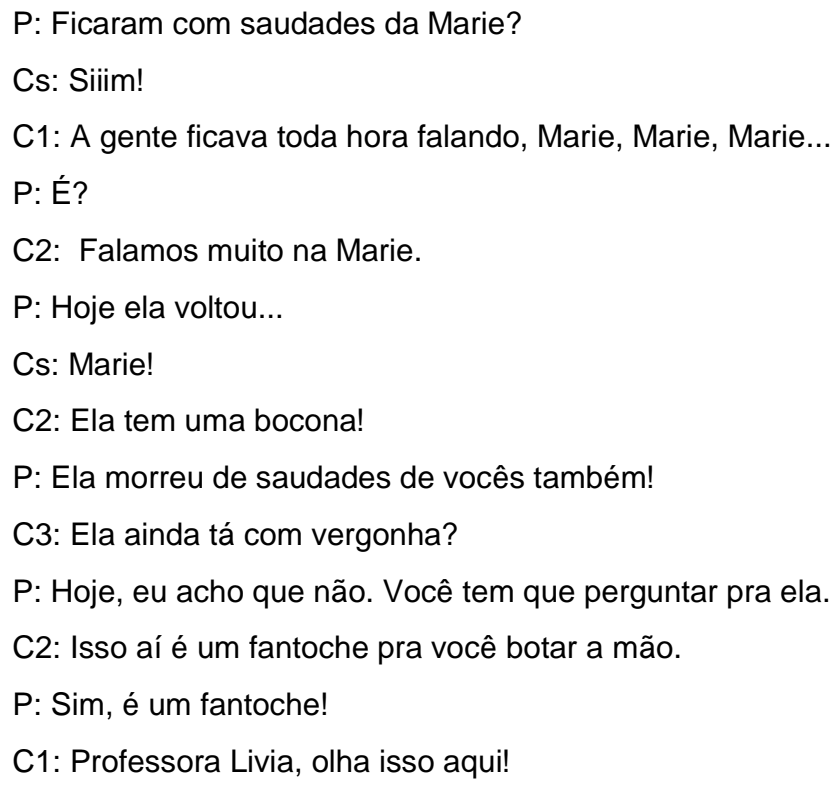

${ }^{68}$ Comentário este que não pôde ser transcrito por ruídos externos no ambiente que impedem a escuta, porém está registrado no diário de itinerância da pesquisadora. 
P: Tá todo mundo machucado...

[todas falam ao mesmo tempo]

$P$ : Crianças, por favor, eu quero falar!

C4: Sim, senhora!

P: Senta no seu lugar, Hudson! Ela tá querendo falar, mas vocês não deixam, aí, ó... Ela vai ficar nervosa!

C1: Ela tá mordendo o seu dedo?

P: Tá mordendo! Você vê que ela morde [...].

C2: É um fantoche!

P: É um fantoche! Todo mundo sabe que a Marie é um fantoche, né?

Cs: Sim, né!

P: É... vamos perguntar pra ela se ela tá com vergonha ainda ou se ela já tá mais feliz?

C2: Cê tá com vergonha?

$P$ : Será como que pergunta, né? Sem ser em português...

C5: Ah, não!

P: Ela fala em francês. Então vamos cumprimentar ela primeiro?

Cs: Bonjour!

C4: Bonjour, Marie!

F: Bonjour, les enfants!

$[\ldots]$

Como se pode ver, uma das crianças (C2) insistiu no fato de Marie ser um fantoche. Neste momento há um conflito entre o real e o fictício, pois foi o comentário anterior que personificava o fantoche que motivou o comentário. Porém, logo em seguida, ao passar para a próxima atividade, a mesma criança que havia questionado o fato de Marie ser um fantoche, vai até ela (que estava em cima de uma mesa, atrás da professora-pesquisadora) a manuseia, balbucia algumas palavras olhando para ela, como se estivessem interagindo, e quando um outro menino pergunta o que a Marie faria, ele responde que ela iria dormir. Observamos aqui que realidade e imaginação se misturam e o fantoche volta a ser personificado, mas dessa vez, na fala da criança. ${ }^{69}$

$\mathrm{Na}$ próxima aparição do fantoche na SO ao perceberem que a professora tinha pegado a caixa onde o fantoche ficava, as crianças começaram a ficar inquietas nas

${ }^{69}$ Este trecho não pode ser transcrito pois a câmera filmadora, que ficava no alto para poder filmar toda a sala de aula, não conseguiu captar perfeitamente o som das vozes das duas crianças em questão, apenas a imagem do manuseio e as vozes de todas as demais crianças que conversavam ao fundo, porém, esta cena, encontra-se registrada no diário de itinerância da pesquisadora. 
cadeiras e no momento em que a professora o tirou da caixa, as crianças começaram a gritar, chamar seu nome e bater palmas, comemorando sua presença ${ }^{70}$.

Nesta sessão, a atividade inicial escolhida foi uma contação de história. Este tipo de atividade, além de estimular a imaginação e a criatividade das crianças, contribui para um enriquecimento do repertório cultural e vocabular e desenvolver melhor a oralidade e a escrita. Dentre outros vários benefícios, é um meio de auxiliar o desenvolvimento das inteligências linguística, espacial, intrapessoal e, também musical e corporal-cinestésica, dependendo dos elementos que compõem a história.

A história foi inventada pela própria professora a partir da seguinte imagem ${ }^{71}$ :

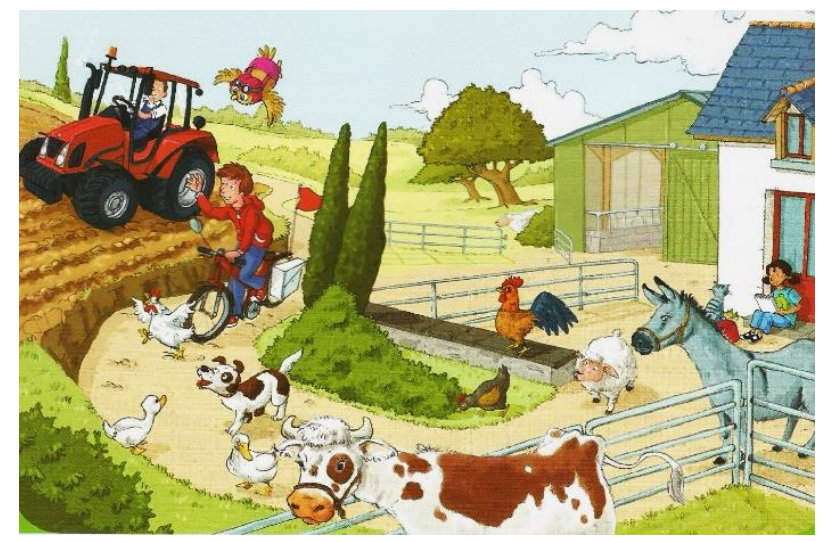

Figura 15 - Imagem para contação de história

Durante a contação, as crianças olhavam atentamente para o fantoche e as imagens dos animais que apareciam ao longo da história ${ }^{72}$. Elas interagiram todo o tempo, imitando o barulho dos animais como veremos também a seguir:

F: Alex va visiter son amie Lila, il arrive dans la ferme de Lila. Haaaan, regarde! C'est la ferme de Lila! Oauf, oauf, oauf oauf... Un chien!

C ?: Cachorro!

$\mathrm{F}:$ C'est un chien ! Bonjour, chien!

\footnotetext{
${ }^{70}$ Vide DVD.

${ }^{71}$ Fonte: VANTHIER, Hélène; SCHMITT, Sylvie. Zig Zag 1: Méthode de Français. Paris: CLE International, 2011.

72 Vide DVD.
} 
Cs : Bonjour, chien !

F : Hihan, hihan, hihan... C'est un âne !

Cs : C'est un âne.

$\mathrm{F}$ : Bonjour, âne !

Cs : Bonjour, Ana!

F : Âne.

Cs : Âne.

F: J'adore les ânes, j'adore!

C?: Eu não gostei ! Não gostei!

F: Alex, il rencontre le papa de Lila : - Bonjour, monsieur ! - Bonjour, Alex! Ahnnn, Lila est là ? Oui, Lila est là ! Coin coin...

Cs : Pato!

C: Coin... Écoute ! Écoute !

C?: Écoute!

C?: Escuta!

F : Coin, coin...c'est un canard! J'adore les canards ! Bonjour, canard !

Cs : Bonjour, canard!

$\mathrm{F}:$ Muuuhh....

Cs : Vaca!

F : Muuuhh, muuuhh... Regarde ! C'est une vache!

Cs : Vacha?

$\mathrm{F}:$ Bonjour, vache !

Cs : Bonjour, vache!

F : Cocoricooo, cocoricooo...

Cs : Galinha, galo!

F: C'est le coq!

$\mathrm{P}$ : Miguel, vamos sentar?

$C 1$ : Mas eu não consigo ver!

P: Consegue sim!

F: C'est un coq! Bonjour, coq!

Cs : Bonjour, Coq!

P: Comment c'est le bruit que le coq fait ? La vache fait muuuhh, muuuhh... Le coc, comment?

C?: Cocoricó!

$\mathrm{F}$ : Cocorico!

C?: Cocoricoo!

F: Ahhhnn! II y a aussi un mouton! Bêêêê...

C?: Carneiro!

F: Bêêêê... C'est un mouton! C'est un mouton! Bonjour, mouton !Bonjour, mouton! Alex entre dans la maison de Lila, et quand il rentre dans la maison de Lila, il écoute : Miaaou...

Cs : Gato!

F: C'est un chat !

C?: C'est un chat? 


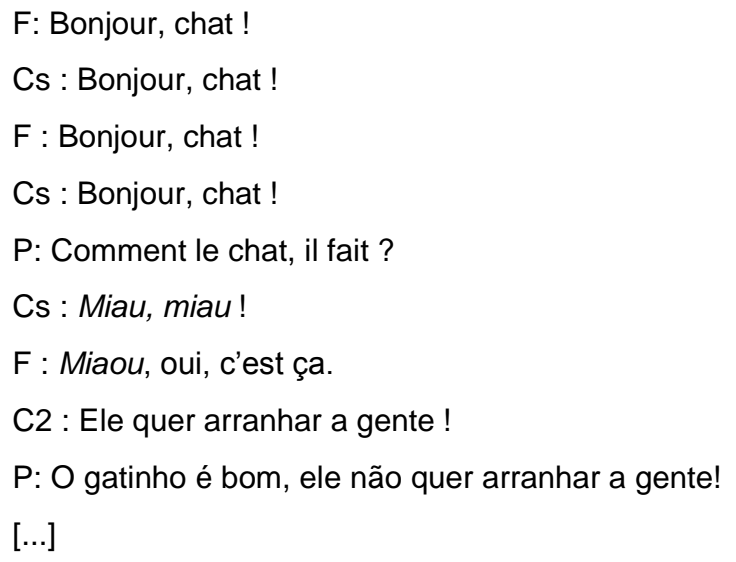

Vale ressaltar que após esta atividade já ter começado, a mesma criança que havia feito os comentários sobre o fato de Marie ser um fantoche na sessão anterior, logo, um ser inanimado, começou a repetir as frases que ela usava durante sua apresentação: "Bonjour, je m'appelle Marie", interagindo e se colocando no lugar do fantoche, mostrando identificação, empatia e aproximação com o agente mediador.

Ao final da história, as crianças estavam envolvidas e ansiavam por mais atividades. A professora-pesquisadora propôs um jogo da memória dos animais e um ditado (a professora-pesquisadora falava um número e um animal e as crianças desenhavam: 3 vaches, 2 chats, 1 chien, 1 canard, 1 mouton, et 1 coq.) e houve participação de todos as crianças com o mesmo nível de atenção e dedicação. Seguem abaixo algumas produções do ditado dos animais:

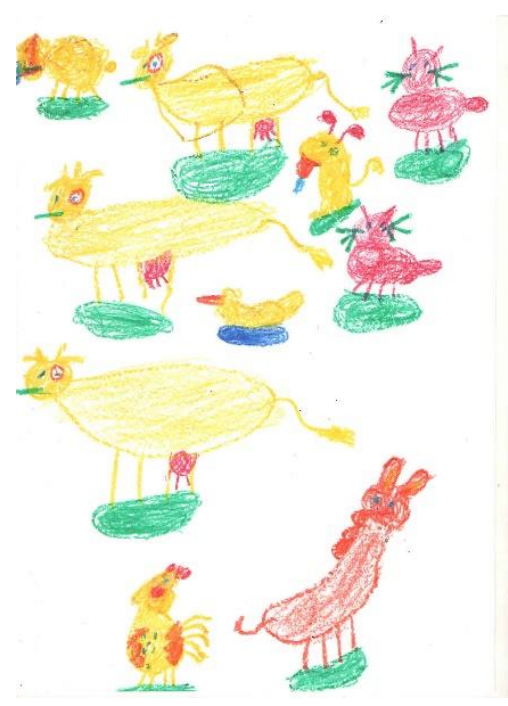

Figura 16 - Ditado - $2^{\text {a }}$ oficina

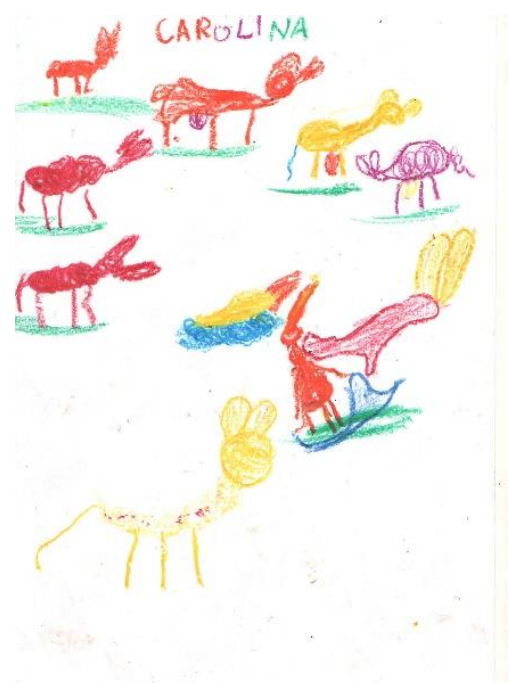

Figura 17 - Ditado $2-2^{a}$ oficina 


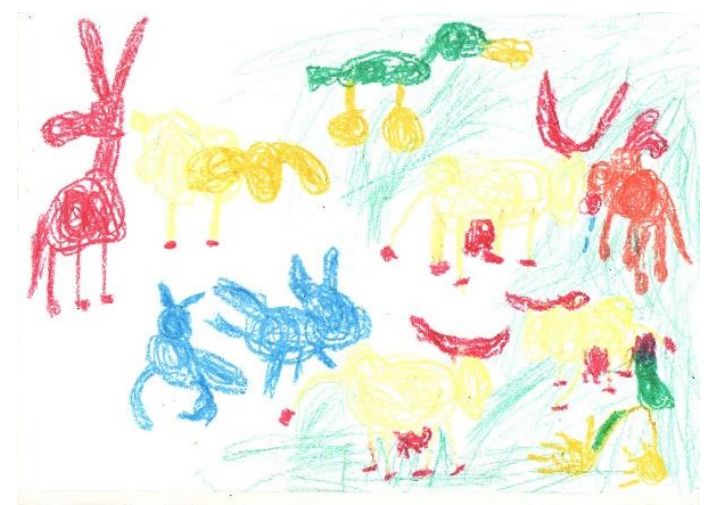

Figura 18 - Ditado $3-2^{2}$ oficina

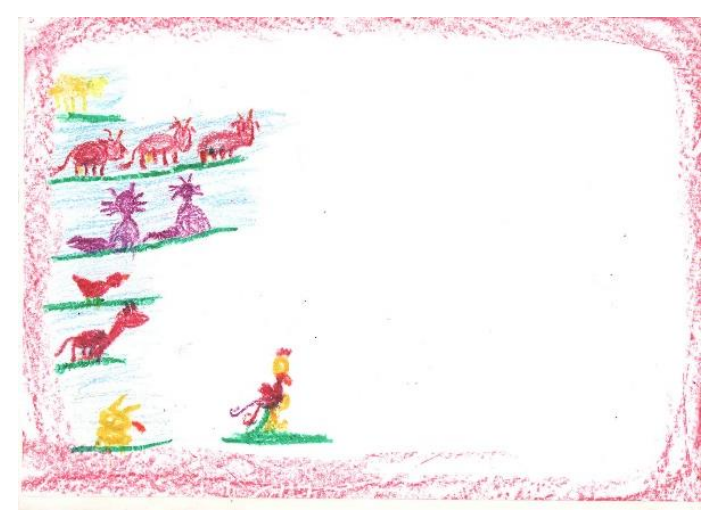

Figura 19 - Ditado 4 - 2ª oficina

Uma outra atividade proposta em uma das sessões da PO se enquadrada na linguagem plástica e consistia na produção de bonecos de papel para a apresentação de uma família.

A professora-pesquisadora ensinou as crianças a fabricarem bonequinhos de mãos dadas e, em seguida, pediu que as crianças colorissem cada boneco de um jeito (como se pode ver nas imagens a seguir), e dessem a cada um deles um nome e uma idade informando que posteriormente as crianças deveriam apresentar suas famílias fictícias ao fantoche.

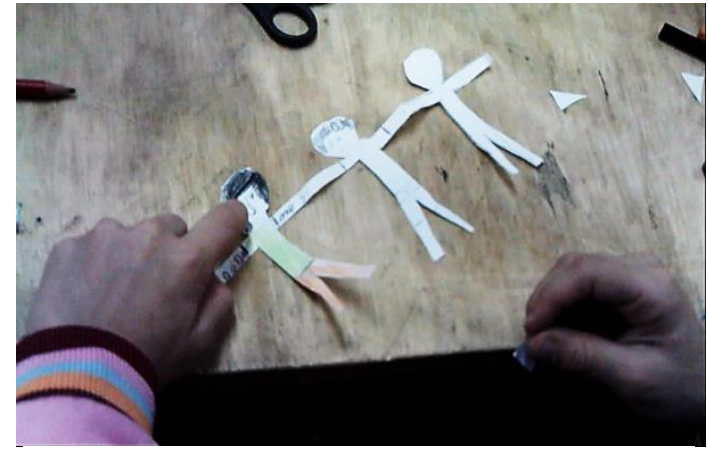

Figura 20 - Fabricação bonecos $-1^{\text {a }}$ oficina

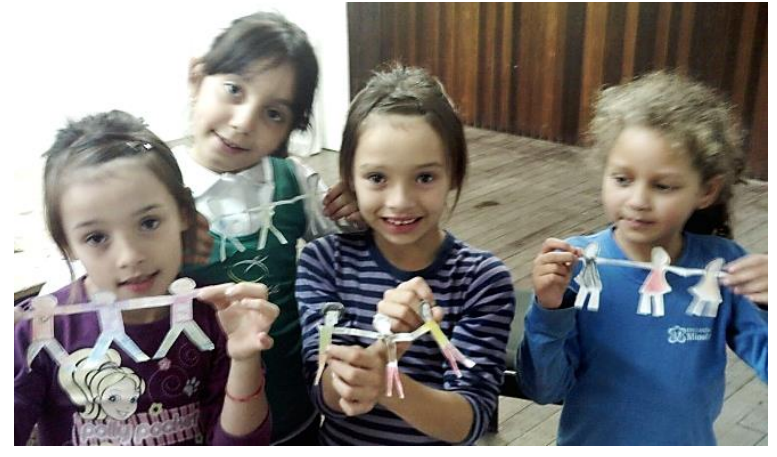

Figura 21 - Bonecos - 1a oficina

É válido ressaltar aqui um fato ocorrido ao final da sessão: terminada a atividade manual, três crianças já haviam ido embora e a câmera já estava desligada, pois a sala estava sendo arrumada. Às costas da professora, que cuidava da arrumação, duas 
crianças que esperavam seus pais começaram a interagir com o fantoche. Uma delas estava com ele na mão e dizia: "Bonjour, je m’appelle Marie" de maneira espontânea e divertida, enquanto a outra criança olhava e respondia. Tal fato aconteceu sem que a professora tivesse pedido ou estimulado as crianças a brincarem com o fantoche $\mathrm{e}$ quando, por fim, houve um breve silêncio e a professora se virou para ver o que acontecera, as crianças sorriram tímidas e pararam de falar, continuando apenas com o manuseio do fantoche.

Respondendo nossas perguntas de pesquisa sobre as atitudes das crianças quando expostas a um agente mediador e também suas interações durante atividades que articulem múltiplas linguagens, podemos observar neste acontecimento espontâneo que é no contexto do jogo, da brincadeira que o agente mediador deixa de ser um boneco, um fantoche, para interagir com a criança como um par. E é no contexto deste jogo dramático que a criança utiliza facilmente a língua estrangeira em aquisição, pois, como afirma Reis (2008:68), o jogo dramático pode "favorecer a comunicação em francês língua estrangeira, reduzindo o medo de errar e a dificuldade de encontrar a 'palavra certa' para expressar o que se deseja".

Esta questão da utilização espontânea da língua estrangeira durante o jogo dramático, se confirma na sessão seguinte. Dando continuidade à atividade de apresentação da família e, devido à interação espontânea que acontecera na sessão anterior, a professora-pesquisadora sugeriu que uma criança segurasse o fantoche enquanto a outra apresentava sua família; desta maneira, todas puderam manuseá-lo, bem como interagir com ele. Embora elas tenham recorrido à ajuda da professora-pesquisadora para dar seguimento à interação que estavam desenvolvendo (como vemos no trecho a seguir), todas as crianças ficaram motivadas e fizeram questão de manusear o fantoche.

C1: Je m'appelle Bia, je m'appelle Gabi et je m'appelle Bernardo.

$\mathrm{P}$ : Aí você pergunta, Sossô : elles ont quel âge?

$F(C 2)$ : Elles ont quel âge?

$\mathrm{P}$ : Muito bem.

C1: Je m'appelle...

P: J'ai... 


$$
\begin{aligned}
& \text { C1: J'ai sept ans. Como é que se fala sete ? } \\
& \text { P: Sept! J'ai sept ans! } \\
& \text { C1: J'ai sept ans, sept. J'ai sept ans, sept. [...] J'ai neuf ans }
\end{aligned}
$$

Estas atividades obtiveram um resultado positivo no que se refere ao nível de interesse, empenho e motivação das crianças e por isso foi feito também na SO sofrendo algumas alterações: a aparição e reapresentação do agente mediador antes da confecção dos bonecos e, infelizmente, a não-manipulação do fantoche pelas crianças, devido ao grande número de participantes.

No início da sessão, as crianças estavam desanimadas e, embora tenham ficado contentes e cumprimentado o fantoche quando ele saiu da caixa, elas questionaram o comentário feito pela professora de que ele teria vindo visitá-los, conversar com eles e ensinar uma coisa nova, dizendo que eles não entediam o que ele dizia, pois ele só falava francês. E após uma mediação da professora com um comentário sobre o assunto, a atividade seguiu com a interação e participação das crianças que ficavam felizes ao descobrir semelhanças entre eles e o fantoche,como vemos a seguir:

P: Alguém veio nos visitar de novo.

Cs: Marie!

P: Ela veio conversar com vocês ensinando outra coisa.

C1: Mas a gente não vai entender, ela falando em francês.

P: Mas vocês entendem, eu falo Bonjour, ça va e vocês entendem, né? Vamos lá...

C2: Porque você explica o que é.

P: Ela vai começar do começo, tá?

F: Bonjour!

Cs: Bonjour!

F: Ça va?

Cs: Ça va?

$\mathrm{F}$ : Je m'appelle Marie. Et vous, comment vous vous appelez ?

C3 : André !

$\mathrm{C} 1$ : Bonjour, je m'appelle João Pedro, et toi ?

$P$ : Vamos cada um falar de uma vez? Vamos começar aqui pela Iris.

$\mathrm{F}$ : Je m'appelle Marie et toi ?

C4 : Bonjour, Iris !

$\mathrm{F}:$ Et toi ?

C5: Caetano.

$P$ : E o Je m'appelle Caetano, ninguém quer falar? Je m'appelle... 
C5: Je m'appelle Caetano.

$\mathrm{P}$ : Muito bem!

[...]

F: J'ai sept ans, et vous?

$P: O$ quê que ela falou?

C6: Ela tem sete anos.

C3: Eu tenho sete!

$\mathrm{P}$ : Então vamos falar pra Marie a nossa idade?

C1: Eu tenho nove!

C2: J'ai sept ans!

$\mathrm{P}$ : Muito bem! Iris, quantos anos você tem?

C4: Seis.

$\mathrm{P}$ : Como que a gente fala seis em francês?

Cs: Six!

P: J'ai six ans.

C4 : J'ai six ans!

F: J'adore le rouge!

Cs: Ela adora...

C5: Ela adora o vermelho!

$\mathrm{P}$ : Isso aí! Ela adora vermelho!

C7: Eu também!

Cs: Eu também, adoro o vermelho!

C6: Eu acertei, eu acertei, eu acertei!

C5: Fui eu!

[todos falando ao mesmo tempo]

P: Primeiro ano, primeiro ano! Eu tenho que ouvir um de cada vez, senão eu não entendo. Então vamos lá, Iris, qual que é sua cor preferida?

C4: Rosa.

P: Rose.

C4: Rose.

$\mathrm{P}:$ E a sua, Caetano?

C5: Rouge.

$[\ldots]$

No decorrer da sessão, as crianças participaram da atividade proposta de produção de bonecos para a apresentação de uma família. Como a quantidade de crianças impediria a apresentação de todos os membros da família naquela mesma sessão, a professorapesquisadora prosseguiu a atividade como na PO (como vemos nas imagens a seguir); porém, explicou que as crianças deveriam escolher apenas um dos bonecos para apresentar ao fantoche. 


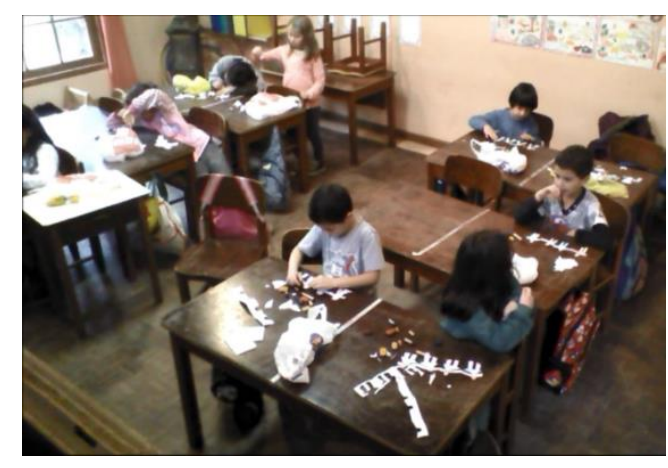

Figura 22 - Fabricação bonecos $-2^{2}$ oficina

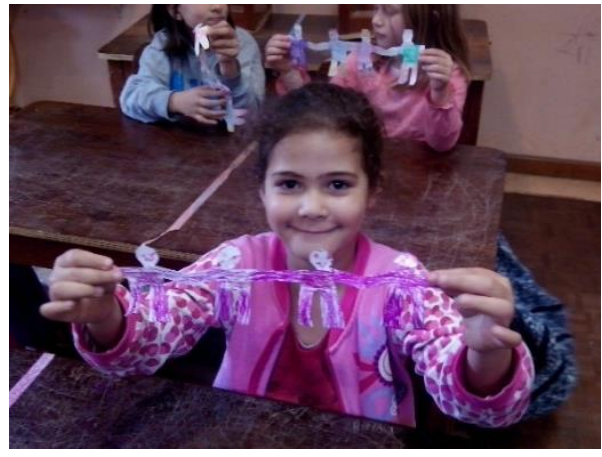

Figura 23 - Bonecos $-2^{2}$ oficina

A continuação da sessão com a apresentação da família ao agente mediador foi bem sucedida, embora tenha acontecido diferentemente, pois como já foi dito, as crianças não manusearam o fantoche. A desenvoltura com a língua francesa foi parecida ao da PO: as crianças tiveram pequenas dúvidas e foram ajudadas pela professora ou até mesmo por outros colegas.

Observou-se também que as crianças ansiavam tanto pela interação com o fantoche para poder apresentar-Ihe seus bonecos que, no momento da apresentação, começavam a falar em LM e só percebiam que deveriam falar em LE quando o fantoche discretamente interferia e dizia "Bonjour, comment tu t'appelles?", obtendo, automaticamente as demais respostas em francês. ${ }^{73}$ Este fato, nos leva a compreender que a presença do agente mediador, não só motiva a participação das crianças nas atividades, como estimula o uso da língua estrangeira, visto que, desde o início das oficinas, as crianças sabiam que o fantoche não entendia a língua portuguesa, realizando, então a comunicação na língua que está sendo adquirida.

Para a última aparição do fantoche em ambas as oficinas, organizamos uma pequena apresentação na qual as crianças utilizaram dedoches fabricados em sessões antecedentes. Nesta apresentação se produziu um jogo dramático em FLE, onde as crianças apresentaram seus dedoches, interagindo com o fantoche e respondendo às perguntas feitas por ele sem que houvesse ensaio ou qualquer ordem previamente

\footnotetext{
${ }^{73}$ Neste momento todas as crianças falavam ao mesmo tempo, o que impediu a boa compreensão do momento exato da interação delas com o fantoche e, consequentemente, a inclusão da gravação deste trecho ao DVD.
} 
estabelecida, mostrando a apropriação da LE pela criança como se pode ver a seguir em trechos da PO e SO, respectivamente:

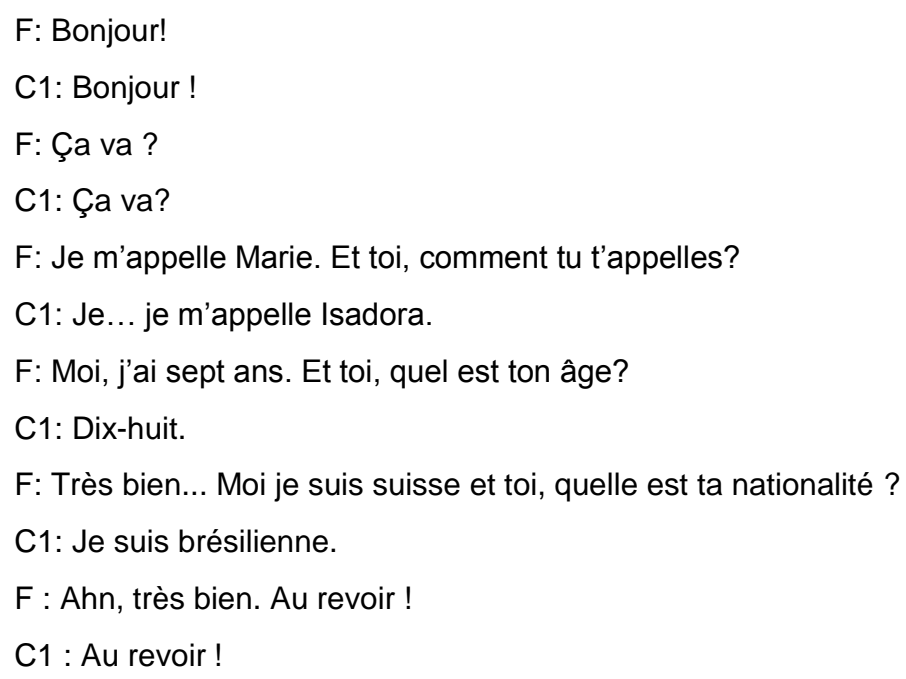

E também:

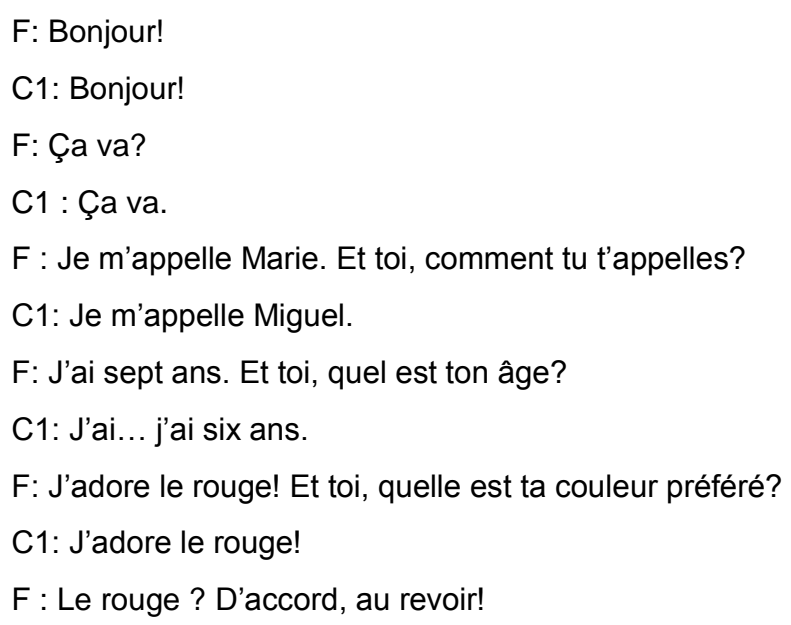

A naturalidade do jogo dramático em LE motivou as crianças a continuarem a brincadeira e, nas duas oficinas, após o jogo dramático com o agente mediador, elas quiseram continuar interagindo com os dedoches dos colegas e o discurso continuou se produzindo em FLE com o auxílio da professora-pesquisadora em alguns momentos. ${ }^{74}$

Após as oficinas, podemos dizer que o uso do agente mediador, além de promover a participação ativa das crianças motivadas por sua presença, como pôde ser visto durante todas as aparições, nos mostra também a maneira das crianças lidarem com a presença de 
duas línguas (LE e LM). A intercalação por vezes se dava na voz da professorapesquisadora, que normalmente estabelecia comunicação com as crianças em LM, falando em francês em algumas situações de retomada de conteúdo como vemos neste trecho:

P: Então, vamos falar pra Marie a nossa idade?

C1: Eu tenho nove!

C2: Que nada, você tem sete!

P: Quantos anos você tem?

C1: Sete.

Mas também na voz das crianças, repetindo frases do fantoche ou respondendo a ele em LE:

F: Bonjour! J'ai six ans! Et toi, quel est ton âge?

C1: É... como que é oito?

$P$ : Huit. J'ai huit ans.

C2: J'ai huit ans. Et toi?

F: J'ai six ans!

Em todas as aparições do fantoche, notamos também, a simples repetição de algumas palavras ou frases por partes das crianças, como vemos nos seguintes trechos: " $F$ : Bonjour, les enfants!/ Cs: Bonjour, les enfants!" ou "F: Je viens de la Suisse et on a une chanson très très chouette. / C1: Très très chouette." Para O'Neil (1993: 200), as crianças nem sempre têm necessidades comunicativas em relação à LE em aquisição. As crianças usam a LE simplesmente "para o prazer" através da repetição de sons, palavras ou frases e segundo ele "este aspecto lúdico da linguagem, o prazer que a criança pequena pode ter em simplesmente manipular sons é muito importante em língua estrangeira"75 (O’NEIL: 1993: 201).

Ou ainda traduzindo para LM como nos trechos a seguir:

F: Je m'appelle Marie, je viens de la Suisse...

C1: Eu vim da Suíça.

75 «Cet aspect ludique du langage, le plaisir que le jeune enfant peut avoir à simplement manipuler des sons, est très important en langue étrangère.» 


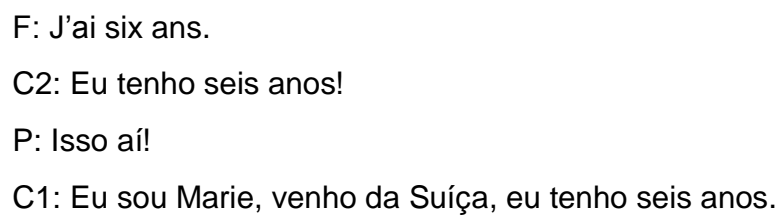

E também: "F: Bonjour, je m’appelle Marie, j'ai sept ans, je suis suisse et j'adore l'orange! / C1 : Ela adora laranja!"

A questão da intercalação da língua estrangeira e da língua materna foi recorrente em ambas as oficinas. Enquanto aprendizes de FLE, as crianças começam, palavra por palavra, a construir sentidos nesta língua, até que chegarão a estruturas mais complexas. Sendo assim, é natural que durante este processo a utilização da LM se intercale com a LE, pois a criança está recodificando os conhecimentos que já possui na LM.

\subsection{A evocação ao fantoche}

Refutando nossa hipótese inicial, a recorrência de citações espontâneas ao fantoche não foi numerosa. Durante a PO, composta por 16 sessões, o fantoche foi utilizado em 5 e nas 10 sessões restantes, em apenas duas houve uma evocação ao fantoche por parte das crianças.

A primeira citação ao fantoche foi feita na $8^{a}$ sessão, ou seja, 4 sessões após seu último aparecimento. Logo no início, após o término de uma canção de aquecimento relembrando as partes do corpo estudadas na sessão anterior, uma das crianças interrompe a professora e pergunta:

\footnotetext{
$P:$ A gente vai cantar mais uma vez...

C1: Trouxe a Marie?

C2: Trouxe a Marie?

C3 : Não, ela não trouxe. Ela tá muito cansada...
}

E como podemos ver, antes que a professora dissesse alguma coisa, uma outra criança respondeu, justificando a ausência do boneco, como se este fosse também uma criança. A professora, então concordou com sua afirmação acenando com a cabeça e em 
seguida, a criança que fez a pergunta mudou de assunto e começou a contar algo que acontecera na escola naquele dia.

A segunda evocação ao fantoche aconteceu neste mesmo dia no meio da sessão, após a distribuição de folhas brancas para uma nova atividade de desenho e recorte, como veremos a seguir:

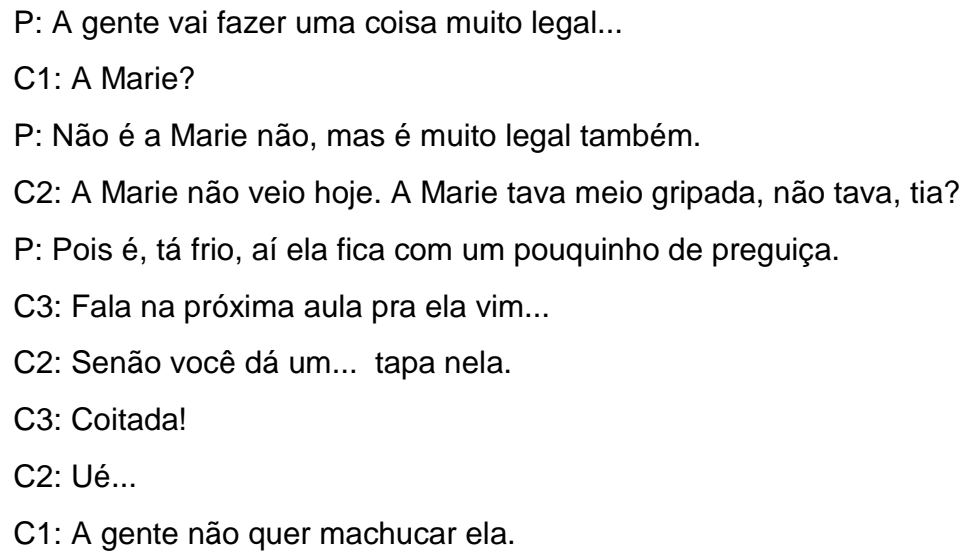

Em ambas as citações podemos ver que as crianças falam e conversam sobre o fantoche de forma natural e espontânea como se ele fosse um colega de turma, uma criança que também fica doente e sente dor, mostrando que diante do agente mediador, as crianças não diferenciam o objeto inanimado - que para elas não é inanimado - delas mesmas, e fazem um apagamento das fronteiras entre as situações reais e as imaginárias.

Propositalmente, na sessão seguinte a professora não levou o fantoche, esperando que as crianças fossem questionar e reclamar, porém nada foi dito e elas participaram das atividades de revisão de vocabulário propostas (bingo de números de 1 a 10, "Jacques a dit" e bingo de cores e frutas) com interesse e atenção.

A próxima evocação ao fantoche aconteceu na $16^{\underline{a}}$ sessão, ou seja, três sessões após sua última aparição, na sessão de número 13. Porém, neste momento, a pergunta de umas das crianças foi motivada por um comentário da professora, que citou Marie para relembrar uma atividade feita anteriormente. Temos então a seguinte interação:

P: Vamos lembrar: no dia que a Marie veio, ela perguntou pra vocês... 
P: A Marie não veio hoje.

C1: Aaaah!

Após esta pergunta as crianças continuam a atividade de construção de um dedoche de papel sem mais questionamentos sobre o fantoche e somente ao final da sessão, quando os dedoches já estavam prontos é que duas crianças "se esconderam" em baixo da mesa, no canto esquerdo (conforme figura abaixo) e uma disse com o dedoche para o alto: "- Oi, Marie!". Acreditamos que esta interação espontânea foi motivada pela presença de uma pessoa desconhecida na sessão (nosso orientador), visto que, desde o início, as crianças estavam curiosas em saber de quem se tratava, visto que ele só se apresentou minutos depois, após a chegada de todas as crianças.

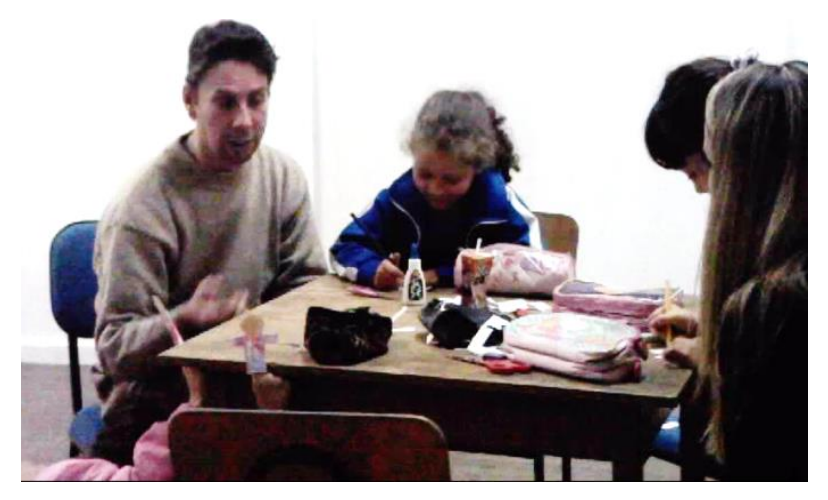

Figura 24 - Crianças e dedoches $-1^{1}$ a oficina

Vale a pena ressaltar que em demais sessões (sessão 9 e 11) a professora igualmente se refere ao fantoche para relembrar um conteúdo aprendido, mas diferentemente desta sessão, as crianças não reagem ao comentário e não perguntam sobre ele, respondendo apenas ao que foi perguntado ou comentado pela professora.

Embora na $\mathrm{PO}$ os comentários sobre o agente mediador não tenham sido recorrentes, percebemos, por parte das crianças, um carinho pelo fantoche. Em todas os comentários feitos por elas, a maneira de tratá-lo ou de se referir a ele, notamos que as crianças o personificam. Elas o tratam como uma pessoa, uma criança em nada diferente delas. Nos momentos em que a professora cita o fantoche mas as crianças não reagem, como dito anteriormente, percebemos que embora elas não falem sobre ele, o fato de 
recorrer à memória afetiva do momento do contato das crianças com o agente mediador, as faz relembrar tudo o que foi dito ou falado por ele, repetindo até mesmo algumas de suas falas como: "Bonjour, ça va? Je m’appelle Marie!”, o que mostra o papel de destaque que o agente mediador tem sobre a aquisição da LE em questão.

Assim como na $\mathrm{PO}$, as evocações ao fantoche na $\mathrm{SO}$ não foram numerosas. A primeira evocação ao fantoche foi iniciada pela professora na sessão de número 11 durante a atividade de construção do dedoche de papel. A atividade já estava no fim quando uma criança pergunta:

C1: Professora, a gente pode levar pra casa?

P: Não, dessa vez vocês vão deixar aqui porque a Marie vai vir conhecê-los.

C1: Aí depois a gente pode?

P: Pode.

C2: Professora, você vai trazer a Marie?

P: Sim (com a cabeça)

E então a criança saiu comemorando e contou para duas amigas.

Tendo tais dedoches prontos, a professora explicou o que seria feito com eles: uma apresentação para o fantoche ${ }^{76}$, na qual seria dito nome, idade, nacionalidade e cor favorita e então a mesma criança que perguntara sobre o fantoche anteriormente diz:

C1: A minha, a minha é a Marie.

$P$ : Mas não pode ser a Marie. A Marie vai estar aqui, tem que ser outra pessoa.

C2: Tem gente que tem o mesmo nome.

$P$ : É verdade.

C2: E o dela pode ser Marie.

$\mathrm{P}$ : Aí tem que ter outra idade, né?

A criança almejava assumir a identidade fictícia do agente mediador e após ser questionada pela professora sobre a incapacidade de duplicidade dos personagens, uma segunda criança, personificando mais uma vez o fantoche, encontrou uma solução para a

${ }^{76}$ Que já se encontra no DVD. 
questão. Logo em seguida todas as crianças começaram a falar sobre seus dedoches e o fantoche não foi mais mencionado.

A segunda evocação ao fantoche aconteceu justamente na sessão seguinte. Neste dia, por pedido da instituição, a professora não fez a apresentação e passou para uma outra atividade. A expectativa era, então, que as crianças logo perguntassem onde estava o fantoche, já que a professora havia dito que ele viria, mas ao chegar na sala, as crianças começaram a questionar sobre seus dedoches e nada falam sobre o fantoche. Este aparente esquecimento, não se trata da desvalorização do fantoche por parte das crianças, mas sim do interesse nos objetos que constituem criação deles. As crianças estavam motivadas a brincar e jogar com um elemento por eles imaginado e criado, criação esta que estimula a criatividade, a imaginação e o desenvolvimento infantil através da linguagem plástica no momento da produção e do jogo dramático na ocasião da brincadeira.

Dando seguimento à sessão, a professora introduz:

P1: Lá na casa da Marie...

C1: Cadê ela?

P; A Marie não veio hoje mas ela mandou contar uma história. Lá na casa dela... onde que a Marie mora mesmo?

Cs: Na suíça.

P: Na Suíça, isso aí! Lá na casa dela, as árvores de Natal são um pouquinho diferentes das nossas. Sabem porquê?

Cs: Não...

P: Lá as árvores são de verdade. Aqui a nossa árvore é de plástico, não é?

$[\ldots]$

$\mathrm{P}$ : Essa árvore que a gente coloca em casa, qual que é o nome dela?

C1: Pinheiro.

P: E lá na Suíça tem muito...

C2: Na minha casa tem pinheiro...

$P$ : E aí, lá na casa da Marie eles tem os pinheiros de verdade, que aí, além de ser bonito e enfeitar, eles dão aquele cheirinho gostoso dentro de casa. E aí, o que é que eles fazem? As crianças, elas fazem as bolinhas pra botar nas árvores, aí mistura as que as crianças fazem com as que a gente compra na lojas. E aí hoje nós vamos fazer as bolinhas, vamos lá?

Cs: Vamos!

Após esse diálogo, a atividade de confecção das bolinhas começou e mais nada foi dito sobre o fantoche. 
Vale ressaltar que na sessão seguinte, quando a professora chegou à escola, viu que em frente à sala de aula das crianças havia uma árvore de natal com algumas das bolinhas confeccionadas enfeitando o topo e ao perguntar à professora responsável pela turma sobre a árvore, esta explicou que as crianças pediram que ela fosse montada e voluntariamente, lá colocaram suas bolinhas, contando que as fizeram na oficina de francês.

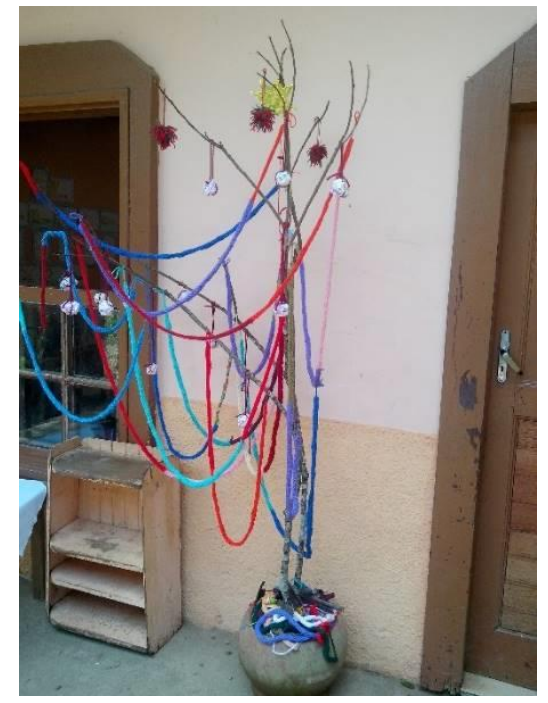

Figura 25 - Árvore de Natal $-2^{\underline{a}}$ oficina

Embora as duas evocações feitas ao fantoche tenham sido, de alguma maneira, motivadas pelo comentário da professora, notamos nessa SO, uma excitação muito maior com o fantoche, se comparada à PO. Os comentários foram escassos, mas quando, de fato, o fantoche aparecia, as crianças ficavam muito contentes e animadas com sua presença, mostrando sempre uma atitude positiva, geralmente reagindo com gritos, palmas e comemorações.

\subsection{Francês em múltiplas linguagens}

A variedade de atividades usando as múltiplas linguagens naturalmente existentes nas crianças e o estímulo às inteligências plurais podem ter influenciado a relação das crianças com o agente mediador, ocasionando tão poucas evocações a ele. Isto porque as 
crianças estavam sempre sendo desafiadas na execução de tarefas e surpreendidas com as propostas não habituais no âmbito escolar trazidas pela professora-pesquisadora, o que as permitia de sempre estimular a criatividade e o interesse pela aprendizagem, não criando grande dependência à presença do agente mediador, embora não se possa questionar o laço afetivo criado entre eles.

As atividades que compuseram as sessões foram pensadas e elaboradas tentando atender às necessidades específicas dos grupos em questão. Sempre baseadas na liberdade do movimento corporal e nas múltiplas linguagens, as sessões continham atividades de todos os estilos: imitação de sons dos animais, contação de histórias, invenção de personagens para estimular a inteligência linguística; canções e cantigas, brincadeiras com ritmos, sons, ruídos, etc. para a inteligência musical; jogos da memória, bingo, quebra-cabeça para a inteligência lógico-matemática; invenção de histórias, desenhos, pinturas para o estímulo à inteligência espacial; atividades que englobassem natureza, animais, comidas para a inteligência naturalista; danças, corridas, jogos de imitação, recorte e colagem, etc. para a inteligência corporal-cinestésica, sempre realizadas em pequenos grupos ou individualmente com apresentação aos colegas e com partilha de ideias e opiniões para auxiliar o desenvolvimento das inteligências interpessoal e intrapessoal.

Todas essas atividades que envolveram o lúdico e o corporal obtiveram reações positivas. Na primeira oficina, as crianças estavam em uma instituição paraescolar de ginástica olímpica onde eram levadas ao desenvolvimento e autoconhecimento de suas habilidades corporais, o que resultou em grande interesse nas atividades que exigiam movimento e agilidade. Mesmo nas atividades que não exigiam movimentos, como a contação de histórias, os momentos de interação com o fantoche, etc., as crianças não paravam de se mover, virando estrelinhas, dando cambalhotas, fazendo alongamentos. Atitudes deste tipo e outras solicitações do grupo dificilmente podem ser previstas e exigem grande capacidade de improvisação do professor. Para se adaptar ao grupo que tínhamos, 
houve um acréscimo progressivo de atividades corporais nesta oficina como jogos de imitação, morto-vivo, etc.

A segunda oficina era composta por um grupo muito maior e o espaço físico, como já foi dito anteriormente, era a própria sala de aula das crianças o que dificultou a inclusão de certas atividades que exigiam grandes movimentos corporais. Nas atividades consideradas essenciais, a professora saía com o grupo para o pátio, o que nem sempre era possível devido às condições climáticas. Porém as particularidades deste grupo, assim como as características institucionais - uma escola de pedagogia Waldorf - fizeram a oficina seguir em outra linha, com enfoque em atividades que exigiam controle motor fino como recorte, desenho, pintura, artesanato, dobraduras, etc.

A inserção das múltiplas linguagens no cotidiano infantil significa possibilitar o desenvolvimento integral da criança. Através das múltiplas linguagens, a criança se expressa, se comunica, organiza, se movimenta e imagina. Não se pode privá-las disso no âmbito escolar. Sua inclusão nas oficinas manteve o interesse pelo conhecimento que estava sendo adquirido.

Assim como as múltiplas linguagens, as atividades corporais permitiram à cada criança mergulhar na LE de "corpo e alma" pois como afirma Vieira (2002:30) "toda a estruturação cognitiva é, portanto, influenciada pela atividade perceptivo-motora e a influencia, quer para a compreensão e a assimilação de novas informações, quer para o reforço e o aprimoramento das situações vivenciadas."

O sentir o corpo livre e ter a liberdade de movimentá-lo a qualquer hora, sem o aprisionamento das carteiras escolares e/ou em atividades específicas, pensadas por nós para este fim, criou a ilusão de que em certos momentos das sessões tudo era apenas uma brincadeira. E foi brincando com algo, com o outro e consigo mesmo que as crianças se apropriaram da LE e produziram seus primeiros discursos em francês, e perceberam que a língua estrangeira pode ser usada em inúmeras situações (lúdicas ou não, fictícias ou não) e que elas podem brincar em LE, mas também brincar com a LE. 
A experiência permitiu, por um lado, o desenvolvimento de habilidades que são atreladas às inteligências plurais, e, por outro, o desenvolvimento da competência discursiva em uma língua que não a materna que, atrelada ao desenvolvimento de habilidades em outras linguagens, culminam no desenvolvimento da competência linguageira infantil.

Para O’Neil (1993:141) a motivação tem dois aspectos, "um aspecto externo: é preciso motivar os alunos por meios diversos; e um aspecto interno: o aluno faz determinada coisa por causa de uma motivação pessoal." ${ }^{n 7}$. Podemos dizer que os participantes de nossa pesquisa enquadram-se nos dois aspectos, pois, por um lado, eles foram motivados por meios diversos: atividades variadas, jogos, materiais diferentes e, principalmente, o uso de um agente mediador. E por outro lado, eles se apropriaram da LE, produzindo em francês com o objetivo maior de poder se comunicar com este agente mediador.

O fantoche, muito mais do que o agente que mediava a passagem do nosso conhecimento, se tornou um desdobramento da professora-pesquisadora. Era somente ele quem introduzia a língua francesa, cabendo à professora o papel de auxiliar às crianças a atingirem seus objetivos: entender e dialogar com o fantoche.

Muito mais do que isso, o fantoche se tornou um amigo, um colega de turma que possui uma cultura e uma língua diferente; uma história e uma vida própria. Sua personificação ocorreu em ambas as oficinas e a facilidade com que o personagem adentrou o imaginário das crianças foi surpreendente. Como vimos nas análises, por diversos momentos as crianças justificavam uma ação, um comportamento ou mesmo a ausência do fantoche com informações humanizadas que foram plausíveis para todas elas, pois não houve questionamentos neste âmbito.

Para a aquisição da LE, ousamos dizer que o agente mediador foi a grande razão para o anseio da descoberta da nova língua. Ele foi motivo e motivador da aquisição. A descoberta de sua história era sempre razão de contentamento para as crianças, pois

77 "Un aspect externe : il faut motiver les élèves par des moyens divers ; et un aspect interne : l'élève fait telle chose à cause d'une motivation personnelle.» 
encontravam semelhanças entre eles, e, ao mesmo tempo, era ele quem trazia as novas informações, fossem elas linguísticas ou culturais.

Para finalizar, é interessante notar que embora - e infelizmente - o ensino de línguas estrangeiras às crianças siga uma vertente oposta ao que este trabalho propõe, o que aconteceu nesta experiência de pesquisa mostra que as crianças podem ter prazer em aprender um novo conteúdo, uma nova língua e que seus corpos podem sim ser usados a favor deste processo. O que propomos, foi um ambiente onde imaginação, conhecimento, corpo, receptividade à língua estrangeira e multiplicidade de meios, formas e materiais se entrelaçam, contribuindo para o desenvolvimento da espontaneidade e da criatividade infantil. Acreditamos que foi possível contribuir, então, para o tão almejado pleno desenvolvimento infantil de grande parte dos participantes desta experiência. 


\section{CONSIDERAÇÕES FINAIS}


O ensino de línguas estrangeiras atual visa um processo educativo no qual o aprendiz seja agente de sua própria aprendizagem, desenvolvendo habilidades e competências necessárias ao exercício de seu papel de verdadeiro ator social. Mas, apesar deste cenário favorável, a inclusão de práticas lúdicas que colocam o aprendiz como agente do processo comunicativo e dinâmico é ainda muito restrita.

Deve-se repensar a escola, o currículo, as metodologias e a formação dos professores, de forma a incluir estratégias que cultivem a imaginação, a atividade criadora na sala de aula e incentivem a espontaneidade, a iniciativa, a curiosidade, o questionamento de si mesmo, elementos essenciais que fornecem condições favoráveis para que os alunos possam ter um espaço para a fantasia e para o lúdico, ou seja, um espaço no qual a criança realmente se sinta feliz, confortável e motivada a participar de um processo de aprendizagem criativo e produtivo.

O papel da escola é permitir à criança de viver a infância como o sujeito de identidade e cultura próprias que é. O adulto, o professor desempenha apenas o papel de mediador nesse processo. Sabendo que as exigências curriculares e institucionais não podem sobrecarregar as crianças, o meio é dosar e variar as atividades, contemplando as múltiplas linguagens, a leitura, as brincadeiras, as atividades artísticas, musicais, o jogo, o movimento e as interações sociais.

Meu objetivo principal enquanto professora de língua francesa, em especial para o público infantil, é criar em sala de aula um ambiente onde não haja amarras ao corpo nem à livre expressão das crianças. Contudo, ao começar esta pesquisa, soube que seria audacioso demais tentar atingi-lo sem antes percorrer um caminho que me levasse a melhor compreender como certos elementos intervêm na corporalização e aquisição infantil de uma língua estrangeira, para, então, poder refletir sobre subsídios que aperfeiçoariam minha prática pedagógica. 
De tal modo, nosso objetivo com este trabalho foi, basicamente, analisar a interveniência do agente mediador no processo de apropriação da língua francesa por crianças, discutindo também, a possível contribuição das atividades concebidas a partir de múltiplas linguagens para o desenvolvimento de inteligências plurais também nas aulas de LE.

Pra isso, primeiramente, procuramos entender como se dá o processo de aprendizagem infantil, destacando o papel do corpo, da mediação e das inteligências plurais neste processo. E em seguida, buscamos refletir sobre o lugar que a brincadeira, o jogo dramático e as múltiplas linguagens deve ocupar na aula de língua estrangeira para crianças. Todos os elementos descritos no primeiro capítulo deste trabalho formaram a base para a análise de nosso corpus.

A análise da experiência realizada junto aos dois grupos distintos de crianças a quem tive a chance de lecionar revelou a importância da prática de atividades variadas e diferenciadas, sobretudo no que se refere às atividades corporais, no processo de ensino/aprendizagem infantil de línguas estrangeiras e também a necessidade de uma mudança dos estabelecimentos escolares e na prática pedagógica de professores para que haja uma urgente ressignificação do que se entende por ensinar e aprender.

O agente mediador, objeto central em nosso estudo, se revelou como grande aliado do professor na inclusão da língua estrangeira na sala de aula, pois, além de cativar as crianças e ajudá-las a despertar seu imaginário, ele foi o motivador do interesse pela língua francesa, visto que as crianças almejavam compreender o que ele dizia e falar com ele.

Sabemos que para as crianças participantes desta oficina, a aprendizagem maior não foi da língua francesa em si, mas do uso de uma língua estrangeira. As crianças perceberam que a LE, muito mais do que ser uma maneira diferente de dizer o que elas já sabem na língua materna, pode se tornar um jogo e que com ela se pode brincar e se divertir. 
Este campo, ainda muito pouco explorado, precisa ser objeto de muitas outras pesquisas futuras. Certamente, ainda há muitas descobertas a serem feitas, outras estratégias a serem empregadas em sala de aula, com resultados certamente cada vez mais reveladores.

Não é nossa pretensão sugerir uma interpretação definitiva de como se dá a interveniência de múltiplas linguagens no desenvolvimento de inteligências plurais na criança, tampouco o completo papel do agente mediador na aquisição de uma língua estrangeira, mas esperamos que o nosso trabalho colabore com as reflexões que já vem sendo feitas e sirva de estímulo para prosseguir, visando cada vez mais propor um novo olhar sobre o ato de ensinar. 
REFERÊNCIAS BIBLIOGRÁFICAS 
BARBIER, René. A pesquisa-ação. Brasília: Liberlivro, 2007.

BARBOSA, Ana Mae. Arte educação no Brasil. São Paulo: Perspectiva, 1978.

Arte-Educação: conflitos/acertos. São Paulo: Editora Max Limonad, 1984.

(Org). História da Arte-Educação. São Paulo: Editora Max Limonad, 1984.

BRASIL. Lei no 9.394, de 20 de dezembro de 1996. Estabelece as diretrizes e bases da educação nacional. Diário Oficial da União. Brasília, DF, 23 dez. 1996.

BRASIL. Secretaria de Educação Fundamental. Parâmetros Curriculares Nacionais: arte. Brasília: MEC, 1997.

BRASIL. Ministério da Educação e do Desporto. Secretaria de Educação Fundamental. Referencial Curricular Nacional para a Educação Infantil / Ministério da Educação e do Desporto, Secretaria de Educação Fundamental. - Brasília: MEC/SEF, 1998.

BROUGÈRE, Gilles. Jogo e educação. Porto Alegre: Artes Médicas, 1998.

Brinquedo e companhia. São Paulo: Cortez, 2004.

BUNZEN, Clecio; MENDONÇA, Marcia (Org). Múltiplas linguagens para o ensino médio. São Paulo: Parábola Editorial, 2013.

CAILLOIS, Roger. Les jeux et les hommes. Paris: Gallimard, 1967.

CORMANSKI, Alex. Le corps dans la langue: Les techniques dramatiques dans l'enseignement/apprentissage des langues étrangères. Thèse pour le Doctorat, Université de La Sorbonne Nouvelle / Paris III, 1992-1993.

DANVERS, Francis. $\mathbf{5 0 0}$ mots clefs pour l'éducation et la formation tout au long de la vie. Villeneuve d'Ascq: Presses Universitaires du Septentrion, 1992.

FERREIRA, Martins. Como usar a música na sala de aula. São Paulo: Contexto, 2001.

FRIEDRICH, Janette. Lev Vigotski: mediação, aprendizagem e desenvolvimento: uma leitura filosófica e epistemológica. Trad. Anna Rachel Machado e Eliane Gouvêa Lousada. Campinas: Mercado de Letras, 2012. 
GAONAC'H, Daniel. L'apprentissage précoce d'une langue étrangère. Paris: Hachette, 2006.

GARCIA, Regina Leite. Múltiplas linguagens na escola. Rio de Janeiro: DP\&A, 2000.

GARDNER, Howard. Estruturas da mente: A Teoria das Inteligências Múltiplas. Trad. Sandra Costa. Porto Alegre: Artmed, 1994.

Inteligências múltiplas: a teoria na prática. Trad. Maria Adriana Veríssimo Veronese. Porto Alegre: Artes Médicas, 1995.

HUIZINGA, Johan. Homo Ludens. São Paulo: Perspectiva, 1971.

KISHIMOTO, Tizuko Morchida (Org). O brincar e suas teorias. São Paulo: Pioneira, 1998.

O brincar e a linguagem. In: FARIA, Ana Lúcia Goulart. de; MELLO, Suely Amaral de. (Org.). 0 mundo da escrita no universo da pequena infância. Campinas: Autores Associados, 2012, p. $45-61$.

MASSARO, Paulo Roberto. Teatro e Língua Estrangeira, entre teoria(s) e prática(s): percursos entre o vislumbre e o olhar. Dissertação de Mestrado. Universidade de São Paulo, 2001.

O silêncio e a voz do texto teatral em francês, língua estrangeira. Tese de doutorado. Universidade de São Paulo, 2007.

2008

Teatro e língua estrangeira: entre teoria(s) e prática(s). São Paulo: paulistana,

MOREIRA, Herivelto; CALEFFE, Luiz Gonzaga. Metodologia da pesquisa para o professor pesquisador. 2. Ed. Rio de Janeiro: Lamparina, 2008.

O'NEIL, Charmian. Les enfants et l'enseignement des langues étrangères. Coll. LAL. Paris: Hatier/Didier, 1993.

PIAGET, Jean. Seis estudos de psicologia. Rio de Janeiro: Forense-Universitária, 1967.

PIAGET, Jean. A Formação do símbolo na criança: imitação, jogo e sonho, imagem e representações. 3ª ed. Rio de Janeiro: LTC, 1990. 
PLATAO. Diálogos. Trad. SOUZA, José Cavalcanti de; PALEIKAT, Jorge; COSTA, João Cruz. São Paulo: Abril Cultural, 1972.

PORCHER, Louis, GROUX, Dominique. L'apprentissage précoce des langues. Paris: PUF, col. Que sais-je? 1998.

REIS, Maria da Glória Magalhães dos. O jogo teatral e o jogo dramático no ensino de Francês Língua Estrangeira. Tese de doutorado. Universidade de São Paulo, 2008.

; GUSMAO, Jéssica. A questão da oralidade no ensino de língua estrangeira jogos e textos dramáticos no desenvolvimento da expressão oral em língua estrangeira. Revista Desempenho, v. 11, 2010, p. 84-98.

A expressão em cena: a afetividade, o corpo e a voz na apropriação da língua estrangeira. In: ANDRADE, Mariana R. Mastrella-de.. (Org.). Afetividade e emoções no ensino/aprendizagem de línguas: múltiplos olhares. Campinas: Pontes Editores, 2011, p. 215-248.

RYNGAERT, Jean Pierre. Le jeu dramatique en milieu scolaire. Paris, CEDIC, 1977.

SLADE, Peter. O jogo dramático infantil. Trad.: Tatiana Belinky. São Paulo: 1978.

TRAJANO, Alexandre. O sentido do ensino das artes na perspectiva de $\mathbf{H}$. Gardner. Dissertação de Mestrado, Universidade Estadual Paulista, São Paulo, 2008.

VANTHIER, Hélène. L'enseignement aux enfants en classe de langue. Paris: CLE, 2009. 2011. ; SCHMITT, Sylvie. Zig Zag 1: Méthode de Français. Paris: CLE International,

VIEIRA, Denise. Radanovic. Práticas corporais e ensino-aprendizagem de línguas estrangeiras. Dissertação de Mestrado, Universidade de São Paulo, 2002.

VIGOTSKY, Lev Semenovitch. Pensée et langage. Trad. Françoise Sève. Paris: La Dispute, 1997.

A Formação Social da Mente. Trad. José Cipolla Neto, Luis S. M. Barreto e Solange C. Afeche. São Paulo: Martins Fontes, 1998.

Psicologia pedagógica. São Paulo: Martins Fontes, 2001. 


\section{BIBLIOGRAFIA}


BENVENISTE, Emile. Problemas de lingüística geral II. Campinas: Pontes, 1989.

BOLOGNINI, Carmen Zink. A aquisição de uma segunda língua por crianças: um estudo sócio-interacionista. Dissertação de Mestrado. Universidade Estadual de Campinas, 1985.

BRUNER, Jerome. Uma nova teoria da aprendizagem. Rio de Janeiro: Bloch, 1969.

CARÉ, Jean-Marc; Debyser, Francis. Jeu, language et créativité : les jeux dans la classe de français. Paris, Hachette, 1991.

CHOMSKY, Noam. Reflexões sobre a linguagem. Lisboa: Edições 70, 1977.

CONSEIL DE L'EUROPE. Les langues vivantes : apprendre, enseigner, évaluer. Un Cadre Européen Commun de Référence. Strasbourg : Conseil de da coopération culturelle Comité de l'éducation, 1998.

COURTNEY, Richard. Jogo, Teatro e Pensamento: as bases intelectuais do Teatro na Educação. São Paulo: Pespectiva, 2001.

CUQ, Jean-Pierre; GRUCA Isabelle. Cours de didactique du français langue étrangère et seconde. Grenoble : Presses Universitaires de Grenoble, 2002.

DANTAS-LONGHI, Simone Maria. Como os jogos podem revelar outras dimensões do trabalho do professor de língua estrangeira? Dissertação de Mestrado. Universidade de São Paulo, 2013.

DENARDIN, Mariane Frigo. $O$ encontro de crianças com uma língua estrangeira: "Se eu fosse mágico eu queria passar tudo de novo". Dissertação de Mestrado. Universidade Católica de Pelotas, 2007.

DUFEU, Bernard. Les approches non conventionnelles des langues étrangères. Paris: Hachette, 1996.

GARCIA, Bianca R. V. Quanto mais cedo melhor (?) : uma análise discursiva do ensino de inglês para crianças. Dissertação de Mestrado. Universidade de São Paulo, 2011.

GERMAIN, Claude. Évolution de l'Enseignement des Langues: 5.000 ans d'histoire. Paris, CLE International, 1993.

PUREN, Chistian. Histoire des méthodologies de l'enseignement des langues. Paris, Nathan / Clé International, 1988. 
SKINNER, Burrhus Frederi. O comportamento verbal. São Paulo: Cultrix, 1978.

SILVA, Sergio Luiz Baptista da. A função do lúdico no ensino/aprendizagem de língua estrangeira: uma visão psicopedagógica do desejo de aprender. Dissertação de Mestrado. Universidade de São Paulo, 2003.

TELLIER, Marion. L'impact du geste pédagogique sur l'enseignement/apprentissage des langues étrangères: Etude sur des enfants de 5 ans. Thèse de doctorat. Université Paris-Diderot - Paris VII, 2006.

VALENTIM, Amarílis Aurora Aparecida. A vivência lúdico-improvisacional compartilhada: uma experiência em nível inicial de aprendizagem do Francês Língua Estrangeira (FLE). Dissertação de Mestrado. Universidade de São Paulo, 2008. 